\title{
A luta desarmada dos subalternos
}

\author{
Osmar Moreira dos Santos
}

\section{SciELO Books / SciELO Livros / SciELO Libros}

SANTOS, O.M. A luta desarmada dos subalternos [online]. Belo Horizonte: Editora UFMG, 2016, 185 p. ISBN 978-85-423-0290-5. Available from: doi: 10.7476/9788542302905. Also available in epub from: http://books.scielo.org/id/dty2b/epub/santos-9788542302905.epub.

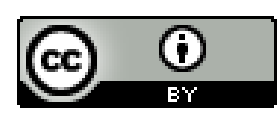

All the contents of this work, except where otherwise noted, is licensed under a Creative Commons Attribution $\underline{4.0 \text { International license. }}$

Todo o conteúdo deste trabalho, exceto quando houver ressalva, é publicado sob a licença Creative Commons Atribição 4.0. 
A LUTA DESARMADA DOS SUBALTERNOS 
UNIVERSIDADE FEDERAL DE MINAS GERAIS

Reitor Jaime Arturo Ramírez

Vice-Reitora Sandra Regina Goulart Almeida

EDITORA UFMG

Diretor Flavio de Lemos Carsalade

Vice-Diretor Roberto Alexandre do Carmo Said

CONSELHO EDITORIAL

Flavio de Lemos Carsalade (presidente)

Danielle Cardoso de Menezes

Eduardo de Campos Valadares

Élder Antônio Sousa Paiva

Fausto Borém

Maria Cristina Soares de Gouvêa

Roberto Alexandre do Carmo Said 
Osmar Moreira dos Santos

A LUTA DESARMADA
DOS SUBALTERNOS

Belo Horizonte

EDITORA UFMG

2016 
(C) 2016, Osmar Moreira dos Santos

(C) 2016, Editora UFMG

Este livro ou parte dele não pode ser reproduzido por qualquer meio sem autorização escrita do Editor.

S2371 Santos, Osmar Moreira dos.

A luta desarmada dos subalternos / Osmar Moreira dos Santos. - Belo Horizonte : Editora UFMG, 2016.

$185 \mathrm{p}$.

Inclui bibliografia.

ISBN: 978-85-423-0177-9

1. Cultura. 2. Cultura política. 3. Civilização moderna. I. Título.

CDD: 301.2

CDU: 130.2

Elaborada pela Biblioteca Professor Antônio Luiz Paixão - FAFICH-UFMG

COORDENAÇÃO EDITORIAL E

PREPARAÇÃO DE TEXTOS Michel Gannam

ASSISTENCIA EDITORIAL Eliane Sousa

DIREITOS AUTORAIS Maria Margareth de Lima e Renato Fernandes

COORDENAÇÃO DE TEXTOS Lira Córdova

REVISÃO DE PROVAS Roberta Paiva

PROJETO GRÁFICO Cássio Ribeiro

FORMATAÇÃO Giovanni Barbosa

IMAGEM DA CAPA TANTO - Criações Compartilhadas

PRODUÇÃO GRÁFICA Warren Marilac

\section{EDITORA UFMG}

Av. Antônio Carlos, 6.627 CAD II Bloco III

Campus Pampulha 31270-901 Belo Horizonte-MG Brasil

Tel. +55 31 3409-4650 Fax +55 31 3409-4768

www.editoraufmg.com.br editora@ufmg.br 
Para Jailma, companheira, que, além dos combates cotidianos, experimenta comigo a vida como obra de arte! Para Luana Lenina, de 3 anos, nossa obra de arte! Para Arrigo de Matos Moreira, como lembrança das "leituras" de Nietzsche aos 10 anos! 


\section{AGRADECIMENTOS}

Ao professor Wander Melo Miranda, supervisor do pós-doutorado, pela generosidade e imensa capacidade de lidar com o múltiplo. Sem esses valores, raros hoje em dia, não teria sido possível mudar "um arquivo de armas" para "uma luta desarmada".

Aos colegas e pesquisadores docentes e discentes que fizeram do Programa Nacional de Cooperação Acadêmica (Procad), entre o Programa de Pós-Graduação em Estudos Literários da Universidade Federal de Minas Gerais (Pós-Lit/UFMG) e o Programa de Pós-Graduação em Crítica Cultural da Universidade do Estado da Bahia (Pós-Crítica/UNEB), um lugar de pensamento crítico-cultural: Eneida Maria de Souza, Maria Nazaré Mota de Lima, Maria Anória de Jesus Oliveira, Edil Silva Costa, Constância Lima Duarte, Jailma dos Santos Pedreira, Reinaldo Marques, Eduardo de Assis, Wander Melo Miranda, Washington Drummond, Anderson Clayton, Evanildes Teixeira, Thainá, Daiane e Ester. Ainda que de longe, devo mencionar a importância das professoras Sandra Goulart Almeida, Leda Maria Martins, Maria Esther Maciel e do professor Luís Alberto Brandão, e das equipes que constituem o Acervo de Escritores Mineiros e da coordenação do Pós-Lit/UFMG. Sem a convivência diária, direta ou indiretamente, com esse lugar de pensamento, não teria sido possível este livro. 
Aos meus colegas e à comunidade do Pós-Crítica/ UNEB, pela alegria e empenho na produção de conhecimento ativo e rizomático. Daqui, o laboratório para a revolução das relações entre a universidade e a comunidade subalterna.

Aos meus pais, Seu Júlio e Dona Sinhôra, por ainda hoje me acolherem como aquele menino que chega de férias.

À Pró-Reitoria de Pesquisa e Ensino de Pós-Graduação da UNEB (PPG/UNEB) e ao seu grupo gestor, por levar a sério as minhas críticas e saber dramatizá-las a favor do desenvolvimento da comunidade unebiana. Assim é minha forma de amar a UNEB: criticando-a, quando deve, e mobilizando minha energia criadora e meus livros a seu favor.

Às agências de fomento Fundação de Amparo à Pesquisa do Estado da Bahia (FAPESB), Conselho Nacional de Desenvolvimento Científico e Tecnológico (CNPq), Coordenação de Aperfeiçoamento de Pessoal de Nível Superior (CAPES) e Financiadora de Estudos e Projetos (Finep), não apenas pelos recursos em apoio à criação da infraestrutura de pesquisa do Pós-Crítica, à mobilidade docente e discente, às bolsas de pós-doutorado, mas, principalmente, pelas bolsas de iniciação científica para as diversas equipes de estudantes que contribuíram com as pesquisas do Núcleo de Estudos da Subalternidade, desde a sua institucionalização, em 2002, no Departamento de Educação do Campus da UNEB em Alagoinhas. Fizemos derivar desse apoio uma imensa produção bibliográfica e técnica, cuja imagem, icástica, este livro procura de alguma maneira exprimir. 


\section{SUMÁRIO}

INTRODUÇÃO

Capítulo 1

A COMUNA DE PARIS E SUA POTÊNCIA SEMIÓTICA 25

Capítulo 2

A LUTA DESARMADA DOS SUBALTERNOS 55

Modos de falar, modos de lutar $\quad 57$

Dostoievski e seus duplos: antídotos à comédia stalinista $\quad 68$ Lições da China $\quad 81$

Capítulo 3

ROTEIROS DE CRÍTICA CULTURAL 101

Beletrismo como sinônimo de conformismo e cooptação 103

República de papeletras como traição de classe $\quad 113$

Letra combativa e socialismo libertário 118

Contradispositivos: equipamentos de crítica cultural como potência literária

Mo(vi)mento 1: prescrição e execução

Mo(vi)mento 2: escritura e salvação

Mo(vi)mento 3: entre a escritura e a proscrição 
Capítulo 4

ATIVISMOS AUTOBIOGRÁFICOS 147

Tecnologias do signo e devir revolucionário nas pessoas 150 Oficina $n^{\circ} 1$

Oficina $\mathrm{n}^{\circ} 2$

Oficina $\mathrm{n}^{\circ} 3$

Oficina $n^{\circ} 4 \quad 156$

Anartivismo indígena no Brasil e o crepúsculo do Estado 159

$\begin{array}{ll}\text { CONCLUSÃO } & 171\end{array}$

$\begin{array}{ll}\text { NOTAS } & 175\end{array}$

$\begin{array}{ll}\text { SOBRE O AUTOR } & 185\end{array}$ 


\section{INTRODUÇÃO}

Seria possível, ainda hoje, empreender um ativismo cultural, social e subjetivo situado entre a luta armada e o conformismo reacionário? A partir desse ativismo, seria possível dizer nem luta armada nem conformismo lambe-botas e, num gesto de extrema coragem e ousadia, reconstruir o espírito político para outras arenas de luta? $\mathrm{O}$ que seria mais corajoso: tomar em mãos uma arma e apagar a vida de alguém ou de uma população inteira ou reconstruir, pacientemente, as condições para a afirmação da vida e dos viventes, onde quer que eles existam?

É claro que nas sociedades humanas há gosto para tudo: desde aquele que acha que a vida na terra é apenas uma passagem e que, portanto, nada do que aqui acontece, em termos de prazer, de gozo, de alegria, mas também de barbárie e de violência, equivale às mil maravilhas do outro mundo, a outros que acreditam que, apesar de tudo, a terra ainda é o melhor dos mundos possíveis. Mas entre uma perspectiva e outra parece valer mais, sempre, arranjar-se um jeito para viver, em comunidade, dando forma ao devir e empenhando a própria vida como um estilo.

Nesse contexto, e de uma perspectiva subalterna, principalmente se demarcarmos aqui o início dos anos de 1980, 
seria muito difícil vislumbrar e criar as condições para que uma pessoa, um sujeito, uma tribo, uma comunidade, uma nação assumisse-se como singularidade e diferença e definisse sua posição na arena pública e política. Tratava-se, nesse período, de uma difícil reviravolta: como deixar de ser um farrapo inventado e produzido pelos sistemas de dominação e, ao mesmo tempo, não ser arrastado pelas palavras de ordem do stalinismo tardio.

Se já no início dos anos de 1950, durante a Guerra Fria, e na Inglaterra, um ativista marxista da nova esquerda, como Raymond Williams, precisava, como um ato político, combater o que Jdanov estava dizendo às pessoas "que parassem de se preocupar com suas pequenas almas e se entregassem ao trabalho duro da construção comunista", como, ainda, segundo Williams, "uma desculpa para a repressão dos escritores na Rússia”, ${ }^{1}$ imaginemos no Brasil, trinta anos depois, às voltas com a luta pelo fim da Ditadura Militar (1964-1985), cujos aparelhos de Estado não apenas controlavam a imprensa, a escola, as instituições jurídicas, mas inviabilizavam até mesmo o direito a reuniões para se debater e praticar políticas.

É nesse tempo de Estado de exceção e de controle do espírito político que Silviano Santiago, em "Outubro retalhado (entre Estocolmo e Frankfurt)", ${ }^{2}$ vai nos dizer que houve uma "falha geológica" no pensamento e prática política no Brasil, depois da Queda do Muro de Berlim, ao deixarmos de discutir, ampla e adequadamente, a relação dessa queda com o contexto político brasileiro. Tudo 
aconteceu como se fosse um mero problema entre alemães orientais e ocidentais e nada disso tivesse a ver com a nossa realidade, e dispara:

Faltam à língua portuguesa falada no Brasil boas discussões e reflexões de peso sobre o grande evento histórico europeu. Isto é, faltaram-nos debates sobre a Queda do Muro e sobre o esfacelamento posterior do bloco soviético; faltam-nos publicações sobre o fim da Guerra Fria. A inusitada situação da cena brasileira como que isentou os cultores da última flor do Lácio de responsabilidade linguística na relação com a atualidade. A omissão ética e política, por sua vez, relegou ao segundo plano a pertinência e a perspicácia do brasileiro letrado no manejo contemporâneo do instrumental de trabalho (...) A própria língua portuguesa é que, por falta de flexibilidade intelectual dos letrados, se tornou tacanha (...) Ao se amesquinhar, a língua portuguesa reduziu, por sua vez, a possibilidade e a capacidade de qualquer falante de se inserir adequada e criticamente na realidade conturbada do final do século. ${ }^{3}$

Ampliando aqui essa noção de "falha geológica", que aparece apenas de passagem no artigo mencionado, este livro, A luta desarmada dos subalternos, ao tempo em que procura descrever e debater o sentido de um ativismo situado entre a luta armada e o conformismo reativo, procura, também, estabelecer as linhas para um diagnóstico, atual, do que seria essa "falha" no magma do fazer e praticar política no Brasil, em especial a partir da chamada Nova República, emergente após a Ditadura Militar. 
Como se trata, em todo o livro, do exercício e da gestão de uma metodologia complexa, parto do conceito de mapa posto em movimento por Gilles Deleuze e Félix Guattari, em "Rizoma”, introdução de Mil platôs, ${ }^{4}$ por se tratar de um conceito que, apesar de complexo e ainda pouco assimilado, já foi submetido a uma multiplicidade de provas, contestações, ensaios e erros, e com resultados científicos e estético-políticos extremamente relevantes e irrefutáveis, a favor tanto da criação de condições de resistência aos sistemas de poder e de saber reacionários, quanto da criação das condições para a emergência de um pensamento mais libertário.

Dito isso, as linhas gerais e segmentadas de um mapa ${ }^{5}$ indicam a experimentação simbólica, a partir de uma ordem discursiva; a construção de um inconsciente político, dramatizando as marcas no corpo de um sujeito ou de uma cultura; a abertura de conexões entre campos disciplinares distintos e capazes de compor uma máquina de guerra antifascista; o desbloqueio do corpo sem órgãos, como condição de dessubjetivação libertária; a constituição de formas de representação desmontáveis e remontáveis; o estabelecimento de condições para uma produção teatral e performática; o lugar do desejo e da política como ponto de ruptura assignificante. Assim, de qualquer ponto, é possível identificar as fissuras dessa "falha geológica".

No início dos anos de 1980, algum jovem brasileiro que fosse um refugiado do rock and roll, e que não estivesse interessado no engajamento à luta operária, impulsionada 
ainda pelo stalinismo tardio, teria à disposição apenas algumas referências de lutas minoritárias, também em seus primórdios e, mais ativamente, em outros países. Ou seja, o sujeito que fora deformado pela escola pública, criada e controlada pelos militares, condenado a consumir cultura de massa exibida, em preto e branco, pela televisão, crivado por todo tipo de problemas familiares, desnutrido, nômade, sem acesso a bibliotecas, museus, nem habilitado a promover reuniões, entre colegas de rua, de escola, de bairros, fora dos parâmetros das reuniões secretas, sindicais e partidárias, esse sujeito só teria alguma chance de assumir a sua palavra no espaço público se, antes, fosse capaz de se repensar, nos termos, por exemplo, do que é estabelecido pela psicanálise ou por outras formas de exploração do inconsciente reprimido, colonizado, destroçado, tanto pela máquina nazifascista quanto por seu antípoda, mais radical, o stalinismo e sua "engenharia das almas".

A pergunta revolucionária, antes de ser feita no espaço público, deveria ser, a duras penas e sob alto risco, no espaço da clínica: qual a marca no corpo e/ou no espírito que se deixa conceituar e, a partir desse conceito, explorar o próprio inconsciente, identificando, nesse fora, as máquinas concretas e abstratas de repressão, controle e de invenção das doenças da subjetivação? E mais do que isso: aprender a desmontar a si mesmo e a remontar-se, no processo, a partir de uma dobra de si ou de um ponto de ruptura assignificante. 
É nesse sentido que Gilles Deleuze, no texto "O que é pensar?", 6 e tratando de uma leitura da obra de Michel Foucault, vai nos dizer que, para fazer funcionar essa questão, seria necessário romper com a proposição de que o pensamento é inato e adquirido e, partindo dos estratos (o que se vê, se cheira, se toca, se ouve, se escuta) que formam e conformam cada pessoa ou vivente, interpelar as formas de saber, de poder e de constituição do si, fazendo emergir um falar que afrontasse o próprio ver e fizesse expandir suas paisagens.

Se o si, nessa relação com o saber e o poder, para implicar um ato e uma expressão libertária, diz, necessariamente, de um trabalho intersemiótico que começa por um conceito ou uma noção que traduza a marca no corpo ou no espírito, mas que não deve esbarrar-se apenas no desejo de se libertar, por exemplo, mas de, aí mesmo, motivado por esse desejo, começar o difícil trabalho de mapeamento dessas máquinas concretas e abstratas da repressão e da violência, e, além disso, conforme Félix Guattari, promover uma práxis micropolítica voltada tanto para uma ressemiotização dessas marcas e traços quanto para a formação de grupos ou grupelhos minoritários com função de implodirem ou anularem blocos de poder disseminados pelo capital mundial integrado, então, no caso do Brasil, com a Queda do Muro de Berlim em 1989 e, logo em seguida, com a Derrocada do Bloco Soviético, em 1991, não havia como estabelecer as condições para um diagnóstico de nossa "falha geológica" sem outro signo 
forte, agora não mais vinculado a marcas nos corpos e nos espíritos reprimidos, mas vinculado à luta coletiva: a noção de comuna a partir da comuna histórica de Paris, aqui transformada em potência semiológica.

O Capítulo 1, "A Comuna de Paris e sua potência semiótica", além de procurar resgatar e ressignificar alguns valores do marxismo destruídos por sua apropriação stalinista e, também, pelo pós-modernismo, como um intérprete apressado da Nova Ordem Mundial, procura ativar e combinar valores do anarquismo - base política da Comuna de Paris - com os valores da sociedade contra o Estado, postos em movimento pelos índios do Brasil antes da ocupação europeia.

Nesse percurso de leitura e exploração de uma cultura política forte, retoma-se a luta de classes coexistindo com uma multiplicidade de outras formas de luta contra o poder e saber reacionários, bem como se estabelece uma arqueologia do pobre no Brasil, pensada e articulada tanto por uma tradição marxista mais democrática, menos autoritária, quanto por uma epistemologia pós-estruturalista que, desde o final dos anos de 1970, passa a ganhar força nos programas de pós-graduação em Letras, no Brasil, a partir da Pontifícia Universidade Católica do Rio de Janeiro, da Universidade Federal de Minas Gerais, da Universidade Federal da Bahia, entre outras.

Uma questão que esse primeiro capítulo propõe para o estabelecimento de um diagnóstico de nossa "falha geológica" é: as lutas minoritárias poderiam prescindir de um 
permanente debate sobre quem produz a riqueza, material e simbólica, além da natureza e da classe trabalhadora, sem sucumbirem ao fetichismo da mercadoria? Ou esta outra pergunta: a querela entre a interpretação marxista da realidade, sem criticar ou autocriticar o stalinismo, e a interpretação pós-estruturalista que, em geral, confunde stalinismo com marxismo não estaria deixando escapar o tempo político de outra solidariedade de classe, que seria, com os pobres, não nos preocuparmos tanto com a interpretação de representações, mas experimentarmos outros processos de mediação em que pobres e subalternos, além de garantias institucionais e epistemológicas para sua autorrepresentação, também pudessem estabelecer os princípios da gestão e autogestão de sua economia simbólica e criativa?

Essas questões suscitadas pelo Capítulo 1, "A Comuna de Paris e sua potência semiótica", se desdobradas em outras questões e tópicos em fóruns locais, territoriais, regionais e nacionais, no Brasil, ou mesmo onde houvesse povos oprimidos pelo capital e suas representações, na forma dos Estados despóticos e opressores, não só teriam sido uma forma de anular a sanha da Nova Ordem Mundial, no dia seguinte à Queda do Muro de Berlim, mas ainda podem ser, atualmente, uma forma de descrever, com precisão, as barbáries promovidas pela globalização contemporânea conduzida pelos Estados Unidos. Entre a possibilidade que passou e a que não cessa de chegar, no Brasil - além de o Partido dos Trabalhadores (PT) vir, com seu trabalho no campo e na cidade ao longo dos anos 
de 1980 e de 1990, ampliando e consolidando a sua base, concorrendo à Presidência da República - tivemos, ainda, a derrubada de um presidente, por força da sociedade civil organizada, simbolizada pelos "caras pintadas", e a assunção ao poder governamental pelo Partido da Social Democracia Brasileira (PSDB), responsável pela redução do Estado a um patamar mínimo, por meio das privatizações das empresas nacionais e da transformação da educação e da cultura num "bom negócio".

O Capítulo 2, "A luta desarmada dos subalternos", além de apresentar outra imagem da revolução promovida pela Rússia, China e Índia, no século XX, através do debate teórico e da literatura, ainda estabelece um crivo para se interpretar o Brasil fora da clave ocidental. É certo que toda a organização marxista que tomou forma nos partidos, sindicatos e suas "correias de transmissão", ao longo do século XX, derivou da revolução soviética, de 1917, mas, em que pese a força dessa disseminação marxista, seus estudos sistemáticos, e numa dimensão popular, nunca foram possíveis na rede de escolas e universidades brasileiras, em função do controle sem tréguas das instituições fascistas que sempre dominaram o Brasil.

Com a Queda do Muro de Berlim e a Derrocada do Bloco Soviético, na virada dos anos de 1980, e a entrada em cena do pós-modernismo como forma dominante de interpretação do Brasil, parece termos abandonado de vez o crivo da economia política, em viés marxista, substituindo-o ou pelo crivo neoliberal da social-democracia brasileira 
ou pela repetição das palavras de ordem vulgarizadas pelo stalinismo. Portanto, se o fascismo, ao longo do século $\mathrm{XX}$, inviabilizou o estudo sistemático da economia política marxista, o stalinismo, mesmo forte em organização de partidos e sindicatos, não foi além das palavras de ordem; como consequência, o Brasil neoliberal só aprendeu a cumprir estatísticas estabelecidas pelos organismos internacionais, a exemplo do Banco Mundial, logo sem nenhuma condição nem mesmo de entendê-las de um ponto de vista econômico-político.

Ainda que a revolução comunista, na União Soviética, tenha sido derrotada, ou temporariamente suspensa, que a China tenha sido forçada a um comunismo de mercado e que a Índia tenha lutado, por quase um século, para expulsar os ingleses de seus domínios e, com isso, conquistado autonomia nacional para decidir sobre o destino da nação, o que poderíamos ou podemos tirar como lição para o Brasil talvez seja: sem luta sistemática e organizada não há como enfrentar o imperialismo, e o Estado deve estar, em algum momento, na mão dos trabalhadores ou de suas representações intelectuais, senão para fazer a revolução comunista, ao menos para suspender a sanha imperialista e suas imposições unilaterais, e estabelecer outros parâmetros para o sentido do Estado-nação, seu desenvolvimento científico e cultural, além de estabelecer outras noções de direitos humanos, cidadania e qualidade de vida para a população. 
O Brasil, como já interpretara Caio Prado, não deve ser apenas um país exportador de matérias-primas para o mundo industrializado, fazendo derivar do saldo da balança comercial, se houver, o mínimo para o investimento em políticas públicas, muito menos, com o neoliberalismo contemporâneo, ser o paraíso dos rentistas, esses sujeitos e/ou organizações transnacionais que tomam dinheiro a juro igual a zero nos Estados Unidos para investirem no país dos juros altos, pois toda a riqueza derivada dessa transação não tem rebatimento social relevante. Se, ao contrário e a exemplo da China, todos os mais de cinco mil municípios brasileiros tivessem suas pequenas e médias indústrias para explorarem toda a matéria-prima existente ou toda a matéria-prima explorável, o que aconteceria?

Se a mandioca, a cana-de-açúcar, o café, o cacau, a borracha, o milho, o feijão, o inhame, mas também todas as frutas tropicais, todas as riquezas minerais pudessem passar por processo industrial, em ampla cadeia produtiva, em centenas de milhares de fábricas espalhadas pelo país, cujas máquinas, dessas fábricas, fossem, em grande medida, pensadas, desenhadas e fabricadas também aqui, qual seria a dimensão, agora, de nossa "falha geológica"? Por que no dia seguinte à Queda do Muro de Berlim e à Derrocada do Bloco Soviético nós não retivemos a experiência política, econômica e industrial socialista e comunitária da União Soviética, da China e da Índia, para comparar com o vampirismo multinacional existente no Brasil e fazer um amplo debate nacional? 
A Queda do Muro de Berlim, então, torna visível um outro muro existente entre o povo pobre e subalterno e o conteúdo e as formas de mediação estabelecidas pela elite intelectual e nacional. Por que a educação e a cultura, como um negócio a ser decidido no âmbito da Organização Mundial do Comércio (OMC), não poderiam ser instituídas e praticadas como um "bem simbólico", acessível a todos, inclusive quanto aos modos de sua produção e circulação, além da geração de emprego, renda e abertura de novos mercados? Por meio da crítica ao jdanovismo cultural e da revolução cultural na China, empreendidas tanto pelo retorno contemporâneo à obra do escritor Dostoievski quanto pelo testemunho de escritores chineses, podemos, aqui, não só avaliar o sentido da institucionalização da malha da cultura, posta em movimento a partir de 2005, pelo presidente Lula e o então ministro da Cultura, Gilberto Gil, mas inserir o campo linguístico-literário, sua cultura do signo, suas noções de direito linguístico e literário, como o lugar de estabelecimento de outro roteiro tanto para se mapearem outros pontos problemáticos da nossa "falha geológica", quanto para indicarem as condições para superá-la.

O Capítulo 3, "Roteiros de crítica cultural”, enfatiza a questão da responsabilidade linguística, por parte dos falantes de língua portuguesa, mas, antes de atribuir responsabilidades e compromissos transdisciplinares, estabelece certas condições para uma arqueologia da grande descoberta científica da área - o signo e a abertura 
do significante - como um fator decisivo no deslocamento da teologia, e seus valores metafísicos acoplados ao funcionamento do Estado e do capital, bem como no deslocamento do positivismo matemático, e seus valores lineares e estatísticos, que sempre se equivocam na conta sobre quem produz a riqueza, além da natureza e da classe trabalhadora que vende sua força de trabalho, e a quem a totalidade dessa riqueza material produzida deve retornar na forma da reparação econômica e da justiça social.

Se, onde quer que haja um tentáculo do capital, há aí, também, um signo religioso comercializando uma passagem do oprimido para o outro mundo, o das mil maravilhas, além disso, uma multiplicidade de déspotas atuando com e acima da lei para inviabilizarem o direito de se afirmar a vida e sua sociabilidade, outra fissura da "falha geológica" - após a Queda do Muro de Berlim e a Derrocada do Bloco Soviético - foi a de não se terem colocado as religiões no rol das produções ou invenções culturais. Se a existência precede à essência, então a essência, para significar a potência do humano na sua relação com forças especiais e para além dele, é uma construção cultural semiologicamente representada.

Assim, o materialismo cultural experimentado na União Soviética, na China, na Índia, e através de religiões que foram apagadas ou excluídas pelas religiões dominantes vinculadas ao capital e ao Estado de exceção seria não apenas uma forma poiética de vincular e celebrar a relação do homem, e dos viventes, com a natureza e com 
um tempo "cairológico" em que, pela experiência na e através da língua e da linguagem, seria possível a abertura de outra forma de transcendência. Através desta o homem, de fato, entraria na história e na historicidade como um gênero (humano), apesar das deformações stalinistas do materialismo histórico e dialético.

A ousadia de experimentar outro tempo histórico (deformado), no âmbito das revoluções e suas formas de barbárie, e retê-lo, no corpo e na memória, como um crivo do que poderia ter sido se não houvesse tanto contratempo (as crises, a contrarrevolução, as dúvidas, a repressão, os assassinatos de Estado, entre outros) constitui o limiar para o trabalho de si, autobiográfico, tanto para se pensar a constituição dos sujeitos, avaliando o papel do Estado e do capital no âmbito de sua produtibilidade, quanto para reinventar-se em suas rotas de fuga e de permanente transgressão.

É assim que o Capítulo 4, “Ativismos autobiográficos”, sobre o devir revolucionário nas pessoas e articulando a noção de sociedade contra o Estado, posta em movimento pelos indígenas brasileiros, apresenta alguns pontos de conexão de nossas lutas históricas, e contra-hegemônicas, como um outro ponto do programa de avaliação de nossa "falha geológica", ao deixarmos passar despercebidos os mesmos colonizadores de 500 anos atrás, só que agora, não mais saltando de suas caravelas, que perfizeram as ondas do mar, mas na forma do Deus-dinheiro e surfando através dos simulacros. 


\section{A P Í T U L O 1}

\section{A COMUNA DE PARIS E SUA POTÊNCIA SEMIÓTICA}

Após a Segunda Guerra Mundial, o modelo comunista - o Estado de partido único, monopólio ideológico, niilismo legal, ateísmo militante, terror estatal e eliminação de todas as instituições de autoridade rivais - foi transferido para a Europa Oriental, a China, o Sudeste da Ásia e, eventualmente, países do Caribe e da África. O comunismo foi dissolvido na Europa Oriental em 1989 e na URSS no final de 1991.

Robert Service, Lenin: a biografia definitiva.

Mesmo quando a Revolução estava ameaçada pelos exércitos brancos e pelas tropas de intervenção, quando a Rússia inteira, ainda em grande parte analfabeta, era devastada pela guerra civil e pela fome, nas piores dificuldades econômicas, o governo soviético consagrou uma energia feroz à defesa dessas investigações artísticas e nunca as considerou como secundárias. Poucos países defenderam com tanta paixão o trabalho e a pesquisa artísticas como a jovem República dos Sovietes, e isto nas mais desfavoráveis condições. É um facto que hoje se esquece com demasiada facilidade.

Posto isto, como compreender que esta formidável efervescência tenha sido bruscamente detida depois da morte de Lénine, e que se tenha assistido a uma degenerescência quase total - com poucas excepções - da arte soviética na época estalinista?

Jean Michel Palmier, Lénine: $a$ arte e a revolução. 
Uma fotografia da Comuna de Paris como uma miríade de signos, não de pixels, nem de cenas acadêmicas, seria mais que uma coleção de fotos, como a do arquivo on-line Amigos da Comuna, mais que uma dezena de eventos rememorando seus 144 anos, mas, radicalmente, um agenciamento epistemológico capaz de combinar marxismo com pós-estruturalismo, tanto para combater daquele sua atrofia stalinista quanto para combater deste sua flutuação reativa de signos. Espera-se, com essa combinação, atingir certas condições para um permanente esvaziamento de signos ao mesmo tempo em que se engendram outras formas de representação do poder na política, decretando, com isso, a abertura de novos processos de criação voltados a uma atualização da estética da existência posta em movimento, há milênios, por pobres e subalternos, e que não cessa de ser reinventada.

O tema da Comuna de Paris e sua dimensão estético-política articularam-se com base nas seguintes estratégias: a) a configuração da Comuna como um evento histórico, descrito por anarquistas e marxistas contemporâneos ao evento, bem como posteriores a ele; b) a instalação de certas condições de distanciamento, no interior do evento, e a partir da peça Los días de la Comuna, de Bertold Brecht; ${ }^{1}$ c) a reconfiguração da Comuna como um operador de leitura de dois livros clássicos: Os pobres na literatura brasileira, organizado por Roberto Schwarz, ${ }^{2}$ e O cosmopolitismo do pobre, de Silviano Santiago. ${ }^{3}$ 
A Comuna de Paris: os assaltantes do céu $u^{4}$ apresenta uma descrição das forças políticas envoltas na guerra franco-prussiana do início da década de 1870. A derrocada do exército e do império de Napoleão III resultou na tomada da capital da França pelas tropas de Bismarck. A defesa nacional foi então assumida pela população de Paris, que não se armou apenas para enfrentar as tropas inimigas, mas também para expulsar a burguesia parisiense (movimento de contrarrevolução articulada por Versalhes). Com isso, as forças militares bismarckianas, de inimigas da burguesia, foram, ao longo dos combates, compradas por ela para massacrar o povo organizado em barricadas. Além de apresentar essa descrição, há o julgamento do Movimento Communard, tomado como ingênuo por suas estratégias e táticas organizativas "pouco profissionais", pelo comunismo internacional.

Em A guerra civil na França, de Marx, ${ }^{5}$ dias após a dizimação completa do povo em armas, temos uma imagem da emergência da classe trabalhadora no poder, ainda que por apenas 72 dias. Nota-se, no texto de Marx, não só uma profunda solidariedade com aqueles que lutaram e deram suas vidas, independentemente de "erros" teóricos e estratégicos cometidos por proudhonianos, blanquistas, republicanistas radicais (exceto, claro, os internacionalistas comunistas), mas a crença de que sua teoria estava cada vez mais se tornando científica. Portanto havia provas cabais, naqueles "erros" cometidos, que um socialismo científico 
era mais que necessário não somente para que a classe trabalhadora (operários e camponeses) pudesse ter um farol para as suas lutas, mas para que, de uma vez por todas, e com a Comuna de Paris, já fosse possível considerar essa mesma classe trabalhadora como sujeito histórico.

Ao contrário do livro de Marx, as leituras de Kropotkin e de Bakunin celebram as formas libertárias de organização dos trabalhares no interior das barricadas, as lições a serem tiradas pelas organizações internacionais de trabalhadores, além de afirmarem que nenhum texto pode, a priori, tornar-se um manual para as lutas futuras. Com base no princípio de que toda e qualquer forma de governo, qualquer instituição burguesa, deve ser questionada e banida, a pertinência dessas leituras consiste em oferecer antídotos ao centralismo nas organizações sindicais e partidárias e, ao mesmo tempo, uma metodologia aberta à conceitualização do acontecimento a partir das armas semiológicas de cada momento de luta e de resistência.

Lenin, relendo a Comuna por meio de Marx, destaca, em $O$ Estado e a revolução, ${ }^{6}$ a supressão do exército permanente pelo povo armado, a constituição de assembleias ao mesmo tempo legislativas e executivas, a supressão dos altos salários do funcionalismo público pelo salário mínimo de operários e a figura do poder como um espaço vazio. E Leon Trotski, baseado em sua experiência como organizador do Exército Vermelho na Revolução Soviética, critica, em A Comuna de Paris, principalmente a não apropriação do Banco da França para o financiamento da luta 
armada, a tomada de Versalhes e a ausência de comando entre os communards, pelo fato de estes não procederem a partir de um centralismo rigoroso.

Lições por lições, o que dizer do centralismo leninista nas mãos de Stalin e seu triunvirato? De Trotski, como um dos triúnviros, e que tempos depois terá sua cabeça despedaçada a golpes de picareta, além da proliferação desse centralismo, suspeito e autoritário, na forma das organizações partidárias e sindicais?

Em "Metodologia para o conhecimento do mundo: como se desembaraçar do marxismo", Michel Foucault ${ }^{7}$ demonstra como o marxismo de Estado não só destruiu o espaço público do debate e da experimentação, como condição para a vida do imaginário político aberto a outras direções e temporalidades, mas, principalmente, destruiu a noção de luta implicada na resistência e criação ante os mecanismos da sociedade disciplinar.

Tanto a noção de luta de classe, proposta por Marx e Engels, quanto as noções atuais de luta minoritárias (envolvendo índios, negros, mulheres, homossexuais, entre outros), além de destruídas pelo marxismo de Estado, isto é, o stalinismo, e banalizadas pelo nazifascismo contemporâneo, precisariam ser repensadas a partir de um crivo epistemológico e político, a exemplo da Comuna de Paris.

A passagem da Comuna de Paris de evento histórico e político para um modo de distanciamento estético-político, posta em movimento aqui neste livro, dar-se-á, num primeiro momento, pelo texto Los días de la Comuna, de 
Bertold Brecht. ${ }^{8}$ Trata-se da encenação de acontecimentos de janeiro a maio de 1871, fazendo-os passar pelo crivo de uma dialética do distanciamento, ou seja, personagens de uma cena revolucionária, de fins de século XIX, em condições de contrastarem sua performance communard, sem se confundirem com a fixação ou canonização do communard estabelecida pela retórica e interpretação stalinista.

Em toda a peça há cenas evocando momentos importantes, a começar pelo dia 22 de janeiro: contra a repressão do governo ao povo e à guarda nacional, uma oficina de recrutamento de cidadãos para o exército do povo. Em 25 de janeiro há o planejamento de Thiers e Jules Favre, em Bordeaux, de aniquilar o povo, uma vez que este mudou a função de suas armas. Já na noite de 17 a 18 de março, na rua Pigalle, Thiers tenta tomar armas do povo, mas este acaba tomando o poder municipal e instala a Comuna.

Em 19 de março, em vez de marchar para tomar Versalhes, os communards realizam eleições nos 20 distritos de Paris para constituir o Conselho da Comuna e se mobilizam para a derrubada da Coluna Vendôme, em homenagem a Napoleão, construída com o bronze fundido de 1.200 canhões conquistados na Batalha de Austerlitz. Em 29 de março, houve sessão inaugural da Comuna e seus decretos, começando com a derrubada do exército permanente e a criação de um exército popular, passando pela igualdade de remuneração, ensino gratuito e acessível a todos, merenda escolar para as crianças, separação entre 
a Igreja e o Estado, trabalho coletivo nas fábricas apropriadas. Enquanto isso acontece, o gerente do Banco da França aguarda, a qualquer momento, sua detenção por parte dos delegados da Comuna.

Entre 15 e 20 de abril, ocorrem a definição do programa da Comuna e a cena de infiltração de inimigos dos communards. Na semana sangrenta de maio, os communards seguem armados de canhões contra os soldados alemães e versalhenses armados de metralhadoras. Paris é incendiada pelos communards e cai a última barricada de Faubourg du Temple, ocorrem os massacres dos resistentes, e o fechamento da peça é feito com aplausos à detonação promovida por Versalhes, cujos personagens, o aristocrata, a senhora burguesa, o arcebispo e Thiers, celebram a dizimação da Comuna e a entrega de Paris a "mesdames et messieurs".

Como estratégia de distanciamento, nessa peça há uma seleção de elementos opositivos e dialetizáveis: repressão e recrutamento, armas para matar e armas para se defender e revolucionar um sistema de dominação, exército permanente e exército popular e contingencial, massacre dos resistentes e perpetuação da chama revolucionária. Tudo isso para se perguntar, em 1967, quase 100 anos depois da Comuna e 50 anos da Revolução Bolchevique, desviada pelo stalinismo: o que fazer para dramatizar uma autocrítica da revolução e levar adiante uma crítica da razão dialética? 
O teatro, então, torna-se uma oficina de recrutamento em condições de confrontar essas marcas no corpo do guerrilheiro e do revolucionário com a vontade sanguinária das máquinas de captura e de poder, de direita e de esquerda, não para assombrar o espírito revolucionário, mas para esconjurar o medo e fazer fugir as máquinas da covardia, disfarçadas de máquinas de guerra.

O que é, afinal, esse distanciamento performático ou, combinado com metodologia nietzschiana, ${ }^{9}$ quem é esse distanciamento performático? É um signo a partir do qual se evocam uma ferida e um fantasma e desdobra-se, através desse recrutamento teatral, numa cartografia de forças reacionárias de direita ou de esquerda como conjuração da barbárie, relativa ao desvio da utopia socialista, e condição para o estabelecimento de outra práxis estético-política revolucionária.

Com a descoberta do poder como um espaço vazio, por meio da leitura e interpretação da Comuna feita por Lenin, anteriormente mencionada, bem como com a descoberta da possibilidade de esvaziamento do significado transcendental fixado na enunciação política como religião ou em enunciados e enunciação da religião como política, posta em movimento pela dramatização e dialética do distanciamento praticada por Brecht, a Comuna de Paris emerge como um operador crítico cultural, indo além de um evento histórico fetichizado pela ortodoxia marxista. 
Munidos desse entendimento, agora estamos em condições de perguntar: se a Comuna é um acontecimento epistemológico e prático que torna vazio o trono dos soberanos, sejam estes religiosos ou políticos, esvaziando também seus enunciados e enunciações, o que aconteceria se todos aqueles que sempre estiveram destituídos da cena, ou seja, da vida política, do governo de si e das cidades, retornassem como potência transvaloradora?

No Brasil, depois de mais de 20 anos de ditatura militar (1964-1985), um acontecimento, que estaria em conexão com essa cena revolucionária no plano estético-político, seria mapeável a partir de dois grandes livros: Os pobres na literatura brasileira, de 1983, de Roberto Schwarz, e O cosmopolitismo do pobre, de 2004, de Silviano Santiago.

A coletânea de artigos do livro organizado por Roberto Schwarz é produzida no estertor provocado pelos efeitos do longo período autoritário da extrema-direita no país e, apesar das diversas perspectivas de abordagem, segue, ao menos do ponto de vista adotado por seu organizador, uma linha epistemológica marcadamente marxista, esta já com forte tradição no Brasil, desde o advento do Partido Comunista de 1922. Acrescente-se a essa tradição também entre nós, ao final da Segunda Guerra Mundial e com a crítica internacional ao autoritarismo da extrema-esquerda, a emergência de uma nova esquerda ${ }^{10}$ aberta com a criação do Partido Socialista Brasileiro encampada por intelectuais do quilate de Antonio Candido, Paulo Emílio 
Salles Gomes e do próprio Roberto Schwarz. Isso torna a intelligentsia brasileira articulada tanto com os procedimentos estabelecidos pelo marxismo contemporâneo na Inglaterra e na França, em suas críticas ao autoritarismo de esquerda, quanto com a orientação do sentido de socialismo no Brasil, como agenciamento e revisão da tradição comunista - e seu veio stalinista, sem perder de vista as contribuições marxista-leninistas.

Já a coletânea de artigos do livro O cosmopolitismo do pobre, de Silviano Santiago, é da lavra do próprio autor, os quais foram produzidos nas últimas duas décadas do século XX, tanto como desdobramento de pesquisas e reflexões desenvolvidas durante o regime militar no Brasil, quanto como um questionamento da epistemologia marxista sob um viés pós-estruturalista. Nesse sentido, uma série de noções caras ao marxismo - a exemplo de luta de classes, sindicatos, partidos comunistas e socialistas, materialismo histórico e dialético, ditadura do proletariado, etapismo histórico, nacionalismo como lugar da construção da consciência de classe, internacionalismo como lugar de enfrentamento dos tentáculos do capital e suas formas de metabolismo e reificação - será questionada e suplementada, revista, reposicionada ou simplesmente abandonada, uma a uma, como categorias já superadas e sem rendimento epistemológico e político.

Após 2003, o Brasil tem tido como bases a cultura como bem simbólico e o acesso às obras universais e aos modos 
de produção alternativos, além da economia da cultura como possibilidade de geração de emprego, renda e criação de um mercado diferencial. Assim, questiona-se em que medida os livros Os pobres na literatura brasileira e O cosmopolitismo do pobre, além de definirem e representarem a pobreza nas letras brasileiras e escaparem da estreiteza nacionalista ou de equívocos neoliberais, funcionariam como um recrutamento do povo brasileiro em contexto de institucionalização da malha cultural.

Santiago, em "Atração do mundo: políticas de globalização e de identidade na moderna cultura brasileira", ${ }^{11}$ destaca o mal-estar do colonizado que, permanentemente, precisa ser dramatizado para que políticos, intelectuais e educadores - os mediadores que facilitariam o trabalho revolucionário junto com os pobres - possam resolver o difícil dilema envolvendo o processo de suas subjetivações marcado pela cultura europeia, enquanto falsas raízes, e pela cultura norte-americana, enquanto labirinto a ser mapeado.

O questionamento da institucionalização da malha cultural, a partir de um crivo communard, implicaria, então, situar uma máquina de guerra móvel em cada um dos mais de 5.000 municípios brasileiros, em que os diversos segmentos culturais (teatro, música, cinema, artes visuais, literatura, entre outros) tivessem representação junto ao poder público tanto na definição e execução do 
plano decenal de cultura, quanto na mobilização da sociedade civil como instância de fiscalização e pressão social.

Assim, o segmento literário, por exemplo e para implicar uma radical atividade anfíbia, ${ }^{12}$ parece dever começar por uma politização do simbólico na sua relação entre o real e o imaginário. ${ }^{13} \mathrm{O}$ que seria um imaginário ativo entre a vontade de ser europeu - e operando em línguas europeias assimiladas - e sem cultura política suficiente para engajar seu modo de vida com e contra o American way of life? Em que medida tal atividade do imaginário, compartilhado entre comunidades, permitiria a construção de um universal em diferença em que os sujeitos subalternos e seus mediadores nem sejam deslumbrados provincianos pelo grande universal, nem localistas ingênuos?

Como na sequência de um filme imaginário, a cidade communard, então, com suas ocas e tribos, senzalas e casas-grandes, mocambos, cortiços, favelas e arranha-céus, quilombos e tendas de sem-terra, entre outros, estaria sendo construída desde os vadios e desordeiros da literatura colonial, ${ }^{14}$ articulados ao poeta antimercantilista, ${ }^{15}$ contra os desmandos do Estado de exceção originário, com seus fanfarrões e donos de latifúndios e escravos, ${ }^{16}$ dramatizados em Martins Pena, perito em mostrar os usos dos aparelhos governamentais como propriedade privada. ${ }^{17}$

Sem lugar equidistante para situar o rico e o pobre, só restariam o brejeiro e a carnavalização para a representação romântica da pobreza, ${ }^{18}$ combinada com a orfandade - sentimento materno violentado -, com a tortura, com 
o desenraizamento e com a reificação -elementos da condição escrava em Castro Alves -,${ }^{19}$ passando por um crivo radical do materialismo em que honradez e humildade não fazem o menor sentido em contexto capitalista e liberal, pois está fundado na mercantilização não apenas da força de trabalho, mas da própria classe trabalhadora. ${ }^{20}$ Isso faz emergir Canudos, em Os sertões, e sua noção de decrepitude da raça, cuja solução viria da construção de barragens, distribuição de cartilhas e aplicação da lei ${ }^{21}$ criada pelo sistema republicano.

Os retirantes operários, em Luzia-Homem, provocariam maior impacto que a mercantilização da mão de obra escrava, ${ }^{22}$ e assim, por força de se pensar a realidade com os instrumentos de saber oferecidos pela própria máquina de dominação, resta apenas reproduzir fetichismos e fazer da miséria uma ficção.

Nessa linha de pensamento e atividade estético-política posicionada contra as anomias e a vontade de dominação do ser, engendradas pelo Estado de exceção ${ }^{23}$ - tomado, aqui, como a suspensão do direito pelos déspotas em suas múltiplas metamorfoses -, temos, ainda, a aproximação do burguês ao mendigo em João do Rio, ${ }^{24} \mathrm{o}$ saber literário sem valor e força de ascensão social em Lima Barreto, ${ }^{25}$ a quase absoluta ausência de acordo entre a pobreza e a palavra nos escritos libertários pré-modernistas, ${ }^{26}$ uma arqueologia, para além da história e dos monumentos, visando, através da imaginação, suprir a ausência de documentos, ${ }^{27}$ ou um 
parêntese questionando o sentido da mediação literária envolvendo pobres e analfabetos. ${ }^{28}$

Manuel Bandeira elege a pobreza como condição do sujeito e método para a forma do poema; ${ }^{29}$ Mário de Andrade, como manancial de riqueza; ${ }^{30}$ Oswald, como potência para expropriar os expropriadores; ${ }^{31}$ Drummond questiona se o lugar do poeta e da poesia faz sentido em sociedade dividida; ${ }^{32}$ Graciliano estabelece o contraponto entre a voz pobre e partida do iletrado e a oca e perigosa do letrado; Clarice Lispector constrói a poética do descondicionamento da ordem burguesa, lidando com personagens vulgares ou abomináveis tanto para a direita quanto para a esquerda; ${ }^{33}$ João Cabral, sem opor severinos e comendadores, faz manifestar a vida em que o retirante vegeta; ${ }^{34}$ Guimarães Rosa, apropriando-se do imaginário popular, colonizado, ocidentalizado, faz da pobreza uma dramatização do insuportável e condição para superar o naturalizado em mitos e contos populares; ${ }^{35}$ Adoniram Barbosa cria a imagem de um trabalhador que se orgulha do seu trabalho, ainda que mal remunerado, habitando uma maloca e buscando instituições legais, como forma qualquer de segurança. ${ }^{36}$ De Machado de Assis à poesia concreta, o funcionamento dessa arte de menos, que expõe, explora e dramatiza a relação entre palavras e coisas, torna visível a manifestação dos funcionários do sistema de opressão e estabelece as condições para oficinas do 
pensamento com outras estruturas lógicas ou antiestruturas paralógicas. ${ }^{37}$

Assim, para se reerguer a cidade communard depois de Canudos e da Paris incendiada, não cabe mais falar pelos pobres como se eles fossem tabula rasa, nem retórica oca e palavras de ordem como se revelassem conceitualização do acontecimento sem estudá-lo ou pesquisá-lo. ${ }^{38}$ Por uma lógica paradoxal, deve-se enfrentar os simulacros e os fetichismos, assumir a lógica do copista e fazer do fragmento o signo de uma totalidade perdida, ${ }^{39}$ levar a literatura a funcionar entre os analfabetos e mediar a proliferação dos diários. É o caso de Carolina de Jesus, cuja escritura implica uma experiência social e um modo de dramatizar o dia a dia do "dinheiro-coisa", ${ }^{40}$ a sobrevivência de quem engendra sua existência catando e comercializando o lixo, como situação extrema de um povo, ou mesmo de uma multidão, que foi despejada linguística, cultural, territorial e ainda ontologicamente, ao longo dos séculos XVI, XVII e XVIII, no Brasil, razão pela qual não cessam de nascer sertanejos, e homens valentes, como os da literatura de cordel, que não se submetem a essa lógica da barbárie. ${ }^{41}$

A partir dessa mediação da crítica literária, que toma como objeto de reflexão e pesquisa um imenso conjunto de textos literários que, por sua vez, abarca cinco séculos de representação sobre o pobre no Brasil, tornamos visíveis os dispositivos de poder que, desde o século XVI, vêm, sistematicamente, não só praticando o genocídio e 
a escravidão, mas inviabilizando o povo pobre de uma tomada de consciência quanto a essas formas de exploração do capitalismo, incluindo a fragmentação de uma língua de expressão política, combinada com a ausência de habitação, a desqualificação cultural e os problemas identitários de longa duração. Assim, não é exagero comparar essa forma de barbárie com as estabelecidas em campos de concentração como em Auschwitz, ${ }^{42}$ em que milhões de judeus desapareceram sem poder testemunhar, ou que assombram os modos do testemunho.

Portanto, o que diriam esses sujeitos se não fossem representados pela literatura, pela crítica e pela historiografia? Como se configurariam as reparações linguísticas, culturais, territoriais e ontológicas se o Estado, enquanto mediador das tensões entre o capital e o trabalho, favorecesse um empoderamento dessa sociedade civil organizada em cooperativas, associações, legiões de pobres e subalternos e, ao mesmo tempo, investisse na destruição do capital e de si mesmo - o Estado - enquanto Estado de exceção?

$\mathrm{O}$ que os segmentos artísticos e culturais, uma vez empoderados através dos planos decenais de cultura, espalhados pelos mais de 5.500 municípios, fariam dos restos e das ruínas provocados pelos processos de modernização, em suas perspectivas histórica, filosófica e estética?

Ao acentuar outros dispositivos de poder e apontar ferramentas para a construção de uma outra pauta político-cultural, em $O$ cosmopolitismo do pobre ${ }^{43}$ dramatiza-se como a mudança do olhar teórico-literário - antes fundado 
no fetichismo da literariedade e, a partir do final dos anos de 1970, comprometido com uma arqueologia do cultural pode não apenas situar as dobras do Estado de exceção em todo o sistema literário e cultural (academias, universidades, programas de disciplinas, programas artísticos, entre outros), mas mobilizar um conjunto de procedimentos para se enfrentar o discurso do Ocidente em sua vontade de nomeação e prescrição, legitimação do despotismo e imposição de uma lógica da repetição e do controle.

Assim, em ensaios como "Democratização do Brasil (1979-1981): cultura versus arte", ${ }^{44}$ Santiago faz emergir a cultura no campo das belas-letras, situando o debate acerca da esquerda política brasileira, antes unida em torno da luta contra a ditadura militar e, em final dos anos de 1970, dividida em suas prospecções culturais. Se, de um lado, e seguindo uma linha stalinista, havia um patrulhamento da arte que se abria ao mercado de bens simbólicos e ao campo de experimentação das formas, sobretudo a partir da música e do cinema, por outro, e contra esse patrulhamento, havia um reposicionamento do debate político, agora mais em torno de uma politização do cotidiano e de uma cotidianização da política para além do Estado, de partidos e de sindicatos.

Da mera representação da cultura no texto literário, teríamos, com esse reposicionamento político, outro procedimento do escritor, agora mais empenhado em criticar todas as formas de poder, de direita e de esquerda, em acolher outros procedimentos em relação ao público leitor, 
em deslocar os usos da aparelhagem do sistema (mídias, instituições acadêmicas, formas de circulação do livro), bem como outro procedimento do pesquisador literário, nos âmbitos crítico, teórico e historiográfico, agora mais preocupado com relações intersemióticas (literatura e música, literatura e cinema, literatura e artes plásticas), tematizações do minoritário, mapeamentos críticos do funcionamento das instituições literárias como aparatos de poder e dobras do Estado de exceção.

É na arte, portanto, que vai se dar, primeiro, esse debate multicultural, essa dramatização da democracia no Brasil, muito longe, ainda, de uma democratização do Brasil. Nessa linha de reflexão, há, nos outros textos que compõem $O$ cosmopolitismo do pobre, uma ampliação das linhas desse debate, bem como a formulação de uma pauta política diferencial.

Como ampliação desse debate multicultural, em "Atração do mundo: políticas de globalização e de identidade na moderna cultura brasileira" ${ }^{45}$ confrontam-se o sentido e as consequências do mal-estar do colonizado; expõem-se as marcas e as violências linguísticas deixadas pelo aparelho repressor e colonial; lamenta-se a ausência de uma política linguística efetiva, fora do campo artístico, e como responsabilidade institucional; enfim, multiplicam-se as interpelações sobre as falsas noções de universalismo ainda presas à dialética da cópia versus o modelo, do particular versus o universal, entre outras, que compõem o sistema intelectual brasileiro. 
$\mathrm{Na}$ literatura brasileira e latino-americana entendida em seu sentido anfíbio, dependente, mas universal, fora do lugar, mas no entre-lugar, apropriando-se do modelo para se tornar uma cópia como potência simbólica - nem nacional nem universal, mas universal em diferença, sendo apropriada pela mídia, mas proliferando-se como sistema de comunicação alternativo, com e contra o sistema, é possível identificar, em Clarice Lispector, por exemplo, ${ }^{46}$ um roteiro político para não sucumbirmos ao fetichismo da mercadoria, bem como aos elementos para uma história do presente fundada numa estética da existência.

Como podemos notar, a definição de uma outra pauta político-cultural para o Brasil, em Silviano Santiago, passa necessariamente não apenas pelo questionamento da noção de "exploração do homem pelo homem" e de suas formas de "emancipação". As noções de poder e suas articulações acerca do nacional e internacional, postas em movimento pelo marxismo mais ortodoxo, mas, principalmente, começando pelo questionamento do sentido do "ser homem" ou, crítico-culturalmente mais bem situado, do "ser homem colonizado", e para isto exigem, antes, um debate sobre o sentido de língua e literatura, o campo linguístico-literário. Assim, a responsabilidade linguística e o compromisso teórico com a invenção de uma arte multicultural, em condições de reverter suas metáforas em conceitos e seus conceitos em metáforas, fazem, a partir disso, se repensar o sistema intelectual como condição para a construção da democracia brasileira como um espaço de 
coexistência de temporalidades e de direitos à memória $\mathrm{e}$ ao trabalho autobiográfico voltado à construção de uma estética da existência por parte dos pobres e excluídos do sistema.

Assim, Santiago, em "Outubro retalhado: entre Estocolmo e Frankfurt", ${ }^{47}$ além de perguntar pelo sentido de não haver mais associação entre obra premiada com o Nobel - nesse caso, o romancista sul-africano J. M. Coetzee e sua responsabilidade linguística - e aquela premiada pela indústria cultural - nesse caso, Paulo Coelho e sua escrita de autoajuda -, destaca, aos falantes de língua portuguesa, o fato de nunca ter havido de forma ampla, e envolvendo toda a sociedade brasileira, um debate sobre a queda do Muro de Berlim, em 10 de novembro de 1989, e o esfacelamento posterior do bloco soviético.

Essa "falha geológica", mais do que legitimar a escrita de um Paulo Coelho e de fazer da retórica comunista, em seu luto stalinista, uma espécie de discurso de autoajuda, impõe não somente uma responsabilidade política e linguística, mas também uma série de procedimentos ao trabalho multicultural libertário, a começar pela ação intelectual nos mais diferentes espaços culturais (da TV e da mídia eletrônica às redes sociais), passando pelo envolvimento da arte e da literatura na pesquisa e dramatização das questões dos pobres e subalternos - e também da pequena e alta burguesia -, até o desfazimento da confusão entre espetáculo e simulacro, ${ }^{48}$ para que, da "agressiva política exterior do governo Lula", se pudesse 
aqui retomar, como um desvio, a questão marxista por excelência: quem é que produz a riqueza, para além da natureza e da classe trabalhadora, e a quem ela deve ser redistribuída?

Reposicionados os questionamentos levantados por esses dois grandes livros, Os pobres na literatura brasileira e O cosmopolitismo do pobre, propomos outras questões não apenas para um diálogo com esses grandes autores da crítica literária e cultural, mas para, talvez, abrirmos outros ângulos e roteiros de trabalho estético-político.

Entre nós, do Núcleo de Estudos da Subalternidade do Departamento de Educação do Campus II da Universidade do Estado da Bahia (UNEB), em Alagoinhas, uma primeira questão que se coloca - já em 2002, ano de sua instituição, mas sem regimento, apenas como espaço acadêmico e nômade de agitação estético-política - é: se o prefixo "sub", de subalternidade, não significa mais "estar abaixo de" - considerando toda e qualquer escala de valor, toda e qualquer forma de hierarquia -, mas uma relação de força, no interior dos sistemas e na malha jurisdicional, que provoca alternância ou radical horizontalidade de poderes, então a questão não é mais se essa ou aquela representação literária, crítica ou historiográfica, implica mediações ou solidariedade de classe (nesse caso, do intelectual em relação ao pobre), mas a de saber se a epistemologia do pobre, em suas formas e modos de funcionamento cultural, seria acolhida, entre os intelectuais, na partilha da gestão, criação e recriação das instituições literárias e culturais. 
Para avaliarmos o sentido dessa pergunta inicial, bem como o ponto da escala epistemológica em que nos encontrávamos, tivemos que repensar as belas-letras de nossa formação, mapear o que se fazia no campo literário nas universidades públicas da Bahia, selecionar o que havia de mais ativo em literatura comparada contemporânea e em crítica cultural, inserir, pela via dos estudos marxistas contemporâneos e pós-estruturalistas, a noção de Comuna de Paris no interior dos estudos marxistas ortodoxos e, por fim, proceder a uma pesquisação envolvendo uma série de coletivos, a exemplo de pesquisadores discentes em iniciação científica, dirigentes culturais, artistas e agitadores em fóruns de cultura microrregional, além dos participantes dos nossos eventos em ativismos de rua, com interpelações públicas. Tudo isso movido por pesquisas regulares e suas culminâncias, como os seminários "Karl Marx: est-éticas do trabalho e devir revolucionário" e "Gilles Deleuze: pensamento em movimento e socialismo libertário" e o grupo de estudos Arte, Cultura e Anarquismo em Lenin e Trotski.

As principais respostas foram: não só o apego ao fenômeno literário inviabilizava a experimentação e o movimento político através do texto literário, mas, principalmente, o modo de funcionamento de suas instituições, a saber, a disciplina, as academias, os rituais, os programas de curso, a pesquisa, as formas de produção e divulgação de resultados junto com comunidade de leitores ou consumidores de representação. Além dessas respostas, uma constatação: o campo linguístico-literário teria sido travado em sua força 
de combate político, institucional e transvalorador e, por isso, em certa medida perdido o seu poder de prometer.

Com as atividades desenvolvidas no interior do Núcleo de Estudos da Subalternidade, fizemos - e continuamos fazendo - de fato a literatura "sair do campo e entrar em campo" e ir um pouco além: mobilizar seus coletivos no âmbito regional para sua inserção politizada nos processos de institucionalização da malha da cultura posta em movimento pelo Ministério da Cultura e sua política cultural, a partir de 2005.

Se a principal questão cultural para a Revolução Soviética, em seus primórdios, não se tratava de criação de arte proletária, mas da apropriação da riqueza da arte burguesa ${ }^{49}$ para, numa oficina permanente de signos, jogar os nomes contra as coisas nomeadas, mapear os déspotas e seu despotismo, bem como explorar as estruturas de pensamento e imposição de uma lógica burguesa, então o salto revolucionário seria abrir novos processos de criação. Isso serviria tanto para acentuar o lugar de quem de fato tem produzido a riqueza material existente com sua força de trabalho, combinar surrealismo com materialismo histórico e dialético como antídotos ao fetichismo da mercadoria e seus fantasmas e estimular a emergência de outros criadores (do quilate de Shakespeare) que acendesse o imaginário do socialismo e da abolição da luta de classes, quanto para estabelecer a classe trabalhadora no comando do Estado a fim de - além da gestão desses processos de criação - fazer a transição para o comunismo. 
Ao combinar marxismo contemporâneo com anarquismo, acreditamos não ser mais preciso incendiar as instituições; basta, primeiro, situá-las como uma dobra do Estado de exceção e, em seguida, propor e ativar outra lógica e prática de funcionamento, ainda que de modo indireto e por suas frestas. Essa mistura de conceitos, noções, práticas epistemológicas, tradições revolucionárias, modos de abordagem e ordens jurídicas, deve-se a uma necessidade de reter e debater, quase que permanentemente, oposições tais como economicismo versus culturalismo.

Ora, não se trata pura e simplesmente de substituir a proposição "a infraestrutura econômica determina a superestrutura" por "há uma semiautonomia das esferas econômica e cultural", pois se há ao menos uma cabeça, a de Marx, capaz de ser indeterminada pelas forças econômicas, não podemos então dizer infraestrutura econômica (cotidiano, Estado, economia) determinando a superestrutura ou, tampouco, superestrutura (ciência, religião, arte) determinando a infraestrutura. A radicalidade é confrontá-las, jogar uma contra a outra, para se construírem outros roteiros estético-políticos abertos ao devir: formas do que ainda não existe e engajamento da vida como um estilo. ${ }^{50}$

Entretanto, para se estabelecer essa zona autônoma, esse grau zero, esse lugar de indeterminação, é preciso recuperar a potência do signo, melhor, exercitar, em oficinas e leituras do paradoxo, outros modos não apenas de jogar os nomes, as designações, contra as coisas nomeadas e designadas, mas de interrogar os modos de representação da 
realidade e as formas de pensamento a ela - representação e reprodução - subjacentes.

Com a introdução da filosofia, política, antropologia, psicanálise, história, sociologia como campos de pensamento oxigenados por sua virada linguística e literária na prática da literatura comparada contemporânea e da crítica cultural, nos estudos do Núcleo de Estudos da Subalternidade, identificamos que toda origem implica um ato de nomeação e que, se a existência precede à essência, esta, como atributo do humano, necessariamente deve ser uma construção histórico-cultural, mediada pela e com a linguagem.

Assim, a existência de uma intensa e múltipla prática semiológica nos cursos de Letras, sob o crivo de uma crítica da cultura, faz desse campo não apenas o lugar de emergência de uma cultura do signo, mas de uma prática metodológica, transversal e rizomática, capaz de liberar as ciências humanas tanto de seu positivismo matemático, como único critério científico, quanto de suas paixões te(le)ológicas.

Uma topografia, então, que conecta Canudos e Comuna de Paris, modernismos e oficinas do signo, barroco, antropofagia, tropicalismo e política cultural contemporânea no Brasil, processos de subjetivação em práticas marxistas, estudos linguísticos e literários como ciência e ação direta, exploração do inconsciente em oficinas de criação em escolas públicas. Tudo isso aponta, evoca e mobiliza uma 
série de acontecimentos que não deixaram desaparecer os seus rastros, os seus restos. Exemplos são a miríade de tribos em sociedades contra o Estado, os milenarismos e barricadas na Cidade Luz, o tempo do trabalho com a palavra artística e também do refazimento do ser nas tramas do Ocidente - política cultural como última prova do Estado de exceção -, linguística e literatura, agora, como máquina de guerra a favor dos direitos linguísticos, escolas públicas e festivais de cultura nos bairros como novas práticas communards.

Esses acontecimentos convergem para a definição de outro estatuto da revolução e do espírito revolucionário: se o Estado de exceção, mais atual do que nunca e principalmente nas sociedades ditas democráticas, esmera-se na suspensão do direito e no posicionamento do déspota no lugar da lei (isso vale para todos os regimentos), então, e contra isso, nada mais atual que o espírito communard, que também se esmera em encarar o poder como um lugar vazio (nunca preenchível por um déspota) e o preceito jurídico como um significado sem transcendência, a exemplo da palavra literária.

Se não há mais espaço para o "terror de Estado", como expressão da classe trabalhadora no poder, a forma mais racional de seu funcionamento seria a da mediação entre capital e trabalho: a sociedade civil organizada em comunas cria as leis e forja, através desse Estado mediador, a sua execução cada vez mais a favor de quem, com a natureza, produz a riqueza material existente, até o ponto de não 
haver mais os detentores dos meios de produção, a alta burguesia, nem ordem jurídica que legitime o Estado de exceção, isto é, o Estado, por força de lei, deve conter, em si, o veneno para o seu próprio perecimento.

E a política, para além do Estado, dos partidos e dos sindicatos, estaria no combate permanente, onde quer que haja dobra do Estado, do déspota que quer substituir a lei e suspender os direitos, e na afirmação e disseminação de outra institucionalidade para as instituições.

Se Lenin, a exemplo de seu avô Alexander Blank, ${ }^{51}$ desejasse levantar-se da sepultura 100 anos depois de 1870 para "dar uma olhada em como as pessoas estarão vivendo então", ${ }^{2}$ por certo, não estranharia a evolução e a forma sofisticada do fetichismo da mercadoria, contra a qual produziu livros memoráveis - haja vista Imperialismo, fase superior do capitalismo. Com certeza, porém, seria impactado quanto ao funcionamento do imaginário político, em especial o do socialismo desviado pelo stalinismo.

Não somente a literatura e a obra de arte sofreram sérias restrições, controle e violência da política como terror do Estado, mas o próprio exercício do pensamento crítico e político, o próprio desenvolvimento da consciência e cultura política da classe trabalhadora.

Se é certo, conforme Eric Hobsbawn, ${ }^{53}$ que, para Lenin, "Moscou teria sido apenas o quartel general do socialismo, até que a ideologia pudesse mudar-se para sua capital permanente em Berlim", para que, em vez da "revolução num 
país só”, de fato, continuasse sua vocação internacional e permanente, ${ }^{54}$ propomos, aqui, a abertura de uma série semiológica com inteiras condições não apenas de se recolocar a "situação revolucionária" 55 como uma ideia viva na cabeça dos pobres e subalternos, a exemplo do que foi uma ideia para Lenin, mas de recolhermos o idealismo stalinista, disfarçado de marxismo, como ruínas da história, a fim de que, pacientemente, o reciclemos, ou simplesmente o deixemos na lata do lixo do autofetichismo.

Assim, a noção de personagem conceitual e múltipla, constituída por pobres e subalternos, não só permite retomar os rastros e os restos de uma classe (pré-operária e proletária) em condições de conectar marceneiros, carpinteiros, ferreiros de Paris a Canudos, Bangladesh à Cidade do Cabo, São Peterburgo a Pequim, mas, principalmente, oferecer uma caixa de ferramentas teórica e metodológica, sob um crivo communard, que instale o theatrum no pensamento e, no caso da crítica literária e cultural no Brasil, leve ao limite a noção de fenômeno literário, criticando e desmontando os dispositivos da disciplinaridade e suas instituições, bem como restituindo aos pobres e subalternos o direito de criar e gerir suas representações.

Em seu trabalho de mediação diferencial, o Núcleo de Estudos da Subalternidade (filiado ao Programa de Pós-Graduação em Crítica Cultural do Campus II da UNEB) em mais de uma década de atividade transvalorativa, tem não apenas pesquisado e confrontado o que 
se tem produzido sobre o pobre e subalterno no Brasil e no exterior, como ainda promovido condições para um efetivo trabalho coletivo e criativo com e a partir dessa multidão despejada de sua língua, cultura e território. Entre seus equipamentos e projetos, destacam-se a proposição e a coordenação geral do "Potências transnacionais emergentes e seus crivos culturais", projeto apoiado pela Fundação de Amparo à Pesquisa na Bahia (FAPESB) e pelo Conselho Nacional de Desenvolvimento Científico e Tecnológico ( $\mathrm{CNPq}$ ), e que envolve grupos de pesquisa de dois programas de pós-graduação da UNEB e da Universidade Federal da Bahia (UFBA) voltados ao estudo e à pesquisa da literatura contemporânea no âmbito do BRICS (Brasil, Rússia, Índia, China, África do Sul), bem como ao intercâmbio internacional com instituições científicas e culturais da Rússia, China, Índia e África do Sul. Isso é suficiente como uma amostra, modesta, do que pode um subalterno e sua comunidade. 


\section{A LUTA DESARMADA DOS SUBALTERNOS}

Segundo Einstein, uma quarta guerra mundial, se houver, será feita de pau e pedra, dada a devastação de uma provável terceira guerra, em que entre os vivos apenas ratos e baratas terão chances de sobreviver. Roland Barthes, por sua vez, já nos disse que, se por uma espécie de barbárie, alguma coisa da humanidade devesse ser salva, essa seria a seu ver um livro de literatura, ou o monumento literário, pois, além de ajudar os sobreviventes a recomporem os saberes e a imagem do real, ainda restituiria ao ser humano a sua potência de simbolizar.

Essa estranha instituição chamada literatura, ${ }^{1}$ além de salvar o acontecimento, vislumbra, na mesma relação de força, o que poderia ter acontecido se não houvesse o que aconteceu, e propõe que, entre a filosofia, a literatura e a história, deva haver, como um direito à vida, a possibilidade da autobiografia e sua potência bioficcional.

Se os pobres salvarão o mundo, conforme Jean-Luc Godard, aqui neste livro estamos mostrando que isso só será possível se suas armas consistirem num ativismo 
situado entre a luta armada e o conformismo. Ou seja, nem luta armada nem conformismo lambe-botas, pois, se a luta armada investe, necessariamente, na destruição da vida, o conformismo anula o ser e sua potência de resistir e de criar.

Uma conexão ativa dos pobres do mundo não tem forma, faz-se como signos que se distribuem como sementes. Defendemos, aqui, todavia, que há instituições as quais, embora frágeis (como a literatura), articulam alguma forma de sintaxe - a exemplo da Comuna de Paris, cujos rastros e restos nos permitem não apenas pensar e mobilizar uma crítica de toda e qualquer forma de dominação, mas construir, no espaço público e com assembleias populares, outras instituições, com e contra as leis, que tornem o funcionamento do Estado como uma instituição de direito público e, por isso mesmo, condenado a perecer juntamente com o capital.

Neste capítulo, confrontado com o primeiro, devemos prestar atenção ao menos em dois movimentos: o funcionamento da literatura e suas instituições no Brasil, país que ainda não passou sequer por uma reforma agrária rigorosa, e o lugar da literatura em países que já fizeram não só uma reforma agrária, mas uma revolução. No primeiro caso, embora possamos ostentar uma verdadeira revolução formal acompanhada de uma forte liberdade de expressão, ainda não fizemos a literatura chegar às comunidades e periferias, como uma política pública e de direitos linguísticos e literários, em que não só sejam 
acessados os clássicos e universais, mas, igualmente, haja acesso aos modos de produção e gestão das representações locais, abrindo e disseminando daí um outro mercado cultural e simbólico. No segundo caso, por sua vez, surge uma imagem muito clara da repressão aos processos criativos e artísticos por parte do Estado, mas, por isso mesmo, uma outra maturidade literária por parte dos escritores que, resistindo aos dispositivos e violências, têm investido mais numa literatura de testemunho e na autobiografia como condição não só de pesquisa do real e do sentimento humano, como ainda de um deslocamento da literatura e seu engajamento com a política de Estado.

Assim, como toda e qualquer forma de Estado é uma construção cultural - bem como suas relações com a religião e o capital -, cabe, então, à literatura, em sua fragilidade institucional, continuar devassando tais relações como seu objeto de pesquisa, cujos resultados, sem finalidade, apontem para o direito de cada vivente a dar forma ao seu tempo e espaço, além de empenhar sua vida como um estilo e afirmação de sua existência. É disso que trataremos nos tópicos deste capítulo.

\section{MODOS DE FALAR, MODOS DE LUTAR}

Ao posicionar-se como marxista, derridiana e crítica pós-colonial num contexto, considerado por ela, democrático-burguês (os Estados Unidos dos anos de 1980), Gayatri Spivak ${ }^{2}$ defende o argumento de que os 
subalternos não falam por três motivos: 1) quanto mais baixa a sua condição social, mais submetidos e enredados numa violência epistemológica e quase metafísica; 2) estão desprovidos de representação política e legal que os faça ser ouvidos; 3) estão aprisionados à lógica da mercadoria e seu consumo, por isso sem condições de reverter seu sinal e superá-los.

Combatendo e confrontando intelectuais franceses, a exemplo de Michel Foucault, Gilles Deleuze, Félix Guattari, além de, indiretamente, intelectuais ingleses da chamada New Left, Thompson, Raymond Williams, entre outros, por esses intelectuais ainda persistirem na manutenção do "sujeito do Ocidente ou do Ocidente como sujeito", a autora vai sugerir, na linha de um stalinismo crepuscular do início dos anos de 1980, que o Outro do Ocidente não é apenas aquele significante que "delira" nos processos de investigação intelectual, mas, concretamente, aqueles países que implantaram um socialismo real e que foram capazes de confrontar o imperialismo.

No lugar da proposição "o subalterno não fala”, apresentamos uma proposição paralela: ele falaria se fosse um proletário (pois defende que nem todo marginal é subalterno), iluminado por uma minoria revolucionária portadora de uma teoria da luta de classes (os detentores de uma teoria da ideologia: hegelianos e marxistas), e que, através de suas organizações de classe (sindicatos, partidos, Estados e suas correias de transmissão), não só 
interpretasse os simulacros que envolvem a mercantilização da vida e das coisas, mas também transformasse essa falsa realidade, ou realidade fetichizada, a favor de uma socialização da riqueza para aqueles que, de fato, a produzem: a classe trabalhadora. Apenas a partir de uma politizada interpretação das leis, implicadas nos embates envolvendo a "divisão internacional do trabalho", é possível fazer os detentores dos meios de produção ouvirem sua voz e reivindicações.

Se essa proposição paralela, que se insinua e se esconde na ambivalência e urdidura de seu texto, faz sentido, então já estamos em condições não apenas de suplementar a proposição (o Oriente revolucionário pode esvaziar o trono do Ocidente), mas de demonstrar que tanto a micropolítica (severamente refutada pela autora) quanto o trabalho revolucionário originário do Oriente (ardilosamente escondido, talvez por pudor democrático-burguês) nos permitem dizer: nem Ocidente nem Oriente, mas uma multiplicidade de articulações e lutas rizomáticas pós-luta de classes.

É nesse sentido que a conversa entre Michel Foucault e Gilles Deleuze, em "Os intelectuais e o poder", 3 distingue a noção de luta contra a exploração capitalista de outra noção de luta contra o poder, sem que, enquanto tais, percam suas conexões rizomáticas. No primeiro caso, articula o proletariado e sua história, seus métodos, seus alvos, suas posições e ideologias; no segundo, alude àquilo que escapa à luta de classes, mas que implica uma luta contra o poder: 
em casa, nas prisões, nos quartéis, nos hospitais, nas escolas, nas igrejas, onde quer que haja dispositivos de vigilância, controle ou opressão.

Essa "descontinuidade geográfica" - ampliando e complexificando o espaço da luta de classes -, além de nos ajudar a repensar a noção marxista de totalização, nos ajuda a abrir caminhos tanto para pensarmos na existência e construção de outros dispositivos emergentes com a cada vez mais complexa "divisão internacional do trabalho" quanto para estudarmos, pesquisarmos, atualizarmos nossas teorias da revolução que, ao fim e ao cabo, devem funcionar nem como palavras de ordem, nem como dogma impondo a conceitualização dos acontecimentos antes de estudá-los e conhecê-los. Se o imperialismo estende os seus tentáculos a todo o planeta, explorando, oprimindo, assujeitando, cabe, onde quer que isso ocorra, reunir os signos dessa exploração e organizar a passagem de assujeitados para a condição de sujeitos dessa e daquela história local.

Se a luta contra o poder (em suas mais diversas manifestações) e não apenas contra a exploração capitalista (própria da luta proletária) implica desvelar, descrever e anular outros dispositivos de controle, classificação, opressão, reificação, fetichização, apagamento e silenciamento, com sua rede de funcionários e burocratas aplicando a lei e/ ou se posicionando como soberanos no lugar da lei, então não se trata de dizer que há, em Foucault e Deleuze, um deslize quanto às noções de representação, seja ela como Vertretung (ato de assumir o lugar do outro numa acepção 
política da palavra) ou Darstellung (visão estética que prefigura $\mathrm{o}$ ato de performance ou encenação), mas, a exemplo da Comuna de Paris, de interpelar os sujeitos implicados no ato de representar se o seu papel é o de prescrever o que o Estado - em seu conluio com o capital - impõe ou o de representar um conjunto de coletivos (e não somente a classe trabalhadora) em busca de sociabilidades libertárias.

Um exemplo, entre inumeráveis, é o filme $A$ história de Qiu Ju, de Zhang Yimou. ${ }^{4}$ Nele, uma camponesa grávida na China comunista, lutando para que o chefe local, agressor de seu marido, peça desculpas ou faça uma retratação pública, esbarra em quase todas as instâncias da burocracia estatal chinesa até conseguir, na mais alta corte - e, em certa medida, contra a sua vontade -, que o chefe local fosse preso, embora ela quisesse apenas que ele se retratasse.

Nesse sentido, sua forma de luta e seus modos de enunciação são singulares e respondem a uma dobra do poder, como acontecimento: confronta o chefe local, expõe representantes do sistema de poder (a cada instância que interpela e supera em sua vontade de justiça), mobiliza seus parcos recursos de camponeses pobres para despesas e honorários com os administradores da justiça, ativa sua sensibilidade e inteligência, à medida que os desafios vão se colocando durante seu processo de luta e enfrentamento.

Assim, ao contrário do que a teoria de Spivak exige, Qiu Ju não só fala e se faz ouvir - dobrando, esvaziando e jogando as estruturas de poder contra si mesmas -, mas 
faz o sistema de poder (reativo) também falar. O filme $A$ história de Qiu Ju teoriza de forma mais radical a relação entre luta proletária contra a exploração capitalista e luta minoritária contra o poder da teoria pós-colonial que atravessa o texto Pode o subalterno falar?

De um lado, coloca-se a representação (Darstellung) de uma camponesa em sua atividade communard, abrindo mão da sua representação (Vertretung) pelos possíveis representantes (que sairiam dos coletivos da aldeia, mas que são silenciados) e funcionários do poder (que apenas prescreveriam ou estariam acima da lei). De outro, a representação (Darstellung) de uma teórica pós-colonial em sua atividade democrático-burguesa, forçando a execução, $a$ priori, de uma teoria da ideologia que, em vez de prometer e praticar a desmontagem completa do Estado capitalista, apenas prolifera sua mistificação e fetichismo.

Se Spivak posiciona-se teoricamente como uma revolucionária ao afirmar, por linhas tortas, que a diferença radical do Ocidente é o Oriente revolucionário, no entanto, como democrata burguesa, inviabiliza o tempo e o espaço da revolução - em sua anacronia, multiplicidade, coexistência de temporalidades - pela repetição do mesmo etapismo que fundamenta o materialismo histórico que, além de estranho à obra de Marx, revelou-se insustentável com o desvio stalinista.

É certo que, em relação às teses de uma autora do Primeiro Mundo, apegada ainda a alguns valores do 
Segundo (aquele stalinismo crepuscular) para iluminar o Terceiro Mundo, no início dos anos de 1980, muita coisa mudou nesses últimos 30 anos. Em Multidão, Toni Negri e Michael Hardt ${ }^{5}$ não só veem e tematizam, além do povo e do proletário, a legião communard de pobres, esvaziando e reinventado os dispositivos em novos contextos do Império, mas também propõem outro roteiro que inclui outros atores deixados de fora pelo marxismo oficial e abrem novas formas de operar com a noção de comum e de riqueza.

Primeiramente, argumentam que a teoria do trabalho não inclui o lumpemproletário (o desempregado, o mendigo, a sobra ou "exército" de reserva do capitalismo), que também cria, produz, organiza-se em bandos e coletivos transvaloradores. Em seguida, afirmam que, se há uma homogeneização reativa por parte do Império e seus asseclas, a resposta dos pobres - sobre os quais incidem os simulacros e falsos valores - é inverter a política e suas exigências burocráticas por uma biopolítica, em que tomam, à sua maneira e com seus recursos semióticos, o seu próprio corpo marcado, faminto, excluído dos padrões do corpo dócil e útil do mundo do trabalho, como uma linha de fuga ou lugar de produção de resistências, fazendo derivar daí a noção de comum, comunal, como uma prática de vida. Por fim, dizem que há nessa pobreza criativa, transvaloradora e comunal, uma inesgotável fonte de riqueza não expropriável. 
Se há no Império um sistema de controle e vigilância que tende a tornar todo e qualquer ser humano numa espécie de centro de documentação, capturando seus desejos e imunizando os corpos, a legião de pobres, criativos, transvaloradores e em atividade comunal, se (des)anarquivam, permanentemente, à medida que tomam seus próprios corpos como um significante do resto, do anacrônico, do despejado de uma língua, cultura, território e morada do ser.

Num gesto de pura profanação ao American way of life, Giorgio Agamben, em Altíssima pobreza,${ }^{6}$ investiga e demonstra como dos séculos IV ao XIII foram estabelecidas, nos monastérios da Idade Média, as regras e liturgização de vida, bem como sua desconstrução através dos franciscanos e sua forma de vida. Os dispositivos de poder que formam, conformam e permitem operar esse conjunto de regras e normas não só expõem a religião como cultura humana, demasiadamente humana, mas a religa ao Estado e ao capital, daí as razões de seu vigor nas chamadas democracias e/ou autocracias contemporâneas.

A vida no monastério pressupunha que, além da doação de todos os bens à Igreja, como uma primeira condição, o monge devia seguir as regras estabelecidas para o seu dia a dia: da hora de levantar, orar, fazer suas refeições, realizar a leitura das Escrituras, aos trabalhos de limpeza e organização internas. Assim, da vida que seria solitária, nasce, conforme Agamben, "um modelo de vida comunitária 
integral", 7 em que se compartilhava um lugar, uma veste, um habitus, mas fundado na regra da obediência:

Aquele que pede para ser admitido no mosteiro é submetido durante 10 dias a humilhações e insultos para testar a seriedade e a constância de seu propósito: "jogando-se de joelhos diante de todos os irmãos que passam, é por todos expressamente rejeitado e desprezado, como se não quisesse entrar no mosteiro por religião, mas por alguma necessidade prática”. Uma vez que ele tiver suportado tais provas com paciência e humildade, dá-se atenção especial à deposição das velhas vestimentas e à assunção do hábito monacal; mas também esta não basta para que ele seja admitido a pleno título entre os irmãos e durante um ano inteiro deverá ficar na entrada do mosteiro sob a orientação de um ancião. A admissão à condição de monge depende da tenacidade do noviço e de sua capacidade de observar a regula oboedientiae. ${ }^{8}$

Tais regras, normatizações e processos, além de criados e administrados pela Igreja, tinham por base as Sagradas Escrituras que deviam, cotidianamente, ser lidas (memorizadas), para fundamentar a meditação, prescrever as orações e encerrar a contemplação.

Essa ambivalência do sistema religioso, que combina regras e normas de construção da pobreza dos monges, de um lado, e da riqueza e de todo o poder da Igreja, de outro, vai sofrer profundas alterações ao longo dos séculos XI e XII, a partir dos "movimentos religiosos" desencadeados na França, Itália, Flandres e Alemanha, com destaque 
para os franciscanos que, em vez de obedecerem às regras e normas de vida estabelecidas há séculos para os monges, optam por um estilo de vida fundado não mais através das prescrições dos mosteiros, mas conforme o Novo Testamento e as orientações de Jesus de Nazaré. Os franciscanos, conforme Agamben, vão abrir mão da propriedade e afirmar a existência ou forma de vida fora do direito canônico: portanto, o direito natural de uso das coisas, sem possuí-las, a favor da emergência de uma forma de vida não aprisionada a regras e normas.

Nesse sentido, as lições dos franciscanos são bem radicais: primeiro, não fazem questão de ser pobres, ao contrário, afirmam a pobreza em seu extremo, sem propriedades de qualquer natureza, apenas o direito natural de uso das coisas; segundo, esvaziam o direito em seu poder de legitimar a propriedade e o consumo, bem como a forma de vida; terceiro, organizam uma fala ou enunciação que implode tanto o discurso das regras e das normas quanto o do religioso dogmático, afastado da experiência e afirmação de uma forma de vida segundo a doutrina de Jesus de Nazaré; quarto, desmontam o Estado (pela via do direito canônico) e a Igreja (pela via das regras monásticas e do dogmático), bem como afirmam a vida como uma espécie de poiética, fazendo emergir uma interpretação do Evangelho articulada à experiência e engajando a forma de vida num estilo. Temos aqui, então, uma espécie de paradigma do terrorismo $\mathrm{e}^{9} \mathrm{em}$ seu sentido mais afirmativo e inquietante. 
Se o direito é a forma de naturalização da razão e poder do Estado sobre a vida das pessoas em sociedade, fazendo avançar a forma de naturalização da razão da Igreja sobre o sentido metafísico da vida das pessoas em sua existência e não existência (a sua morte), então questionar o direito (no caso dos franciscanos, o canônico) e suas prerrogativas de legitimação do que seja a forma de vida, para os homens em sociedade, é abrir um campo de lutas além de originário, extremamente necessário.

O que aconteceria, hoje, sob a égide do Império, se a legião de pobres (cerca de dois terços da humanidade) procedesse como os franciscanos, questionando o direito de propriedade e de herança, afirmando sua condição de despejados e reivindicando o direito natural de uso das coisas materiais existentes? Qual escritura ou livro sagrado deveria ser lido não para ser memorizado, decorado e transformado em palavras de ordem, mas para funcionar como uma teoria da bioficcionalização e um modo de desmontagem de um si forjado nos laboratórios da brutalidade e da violência epistemológica?

Nas sociedades de controle ${ }^{10}$ não há mais necessidade de mosteiros, prisões, hospícios, campos de concentração para se impor uma regra de vida ou de morte, pois a confusão entre a realidade das formas de vida e as formas de vida como simulacro e fetichização ameaça permanentemente destituir os critérios para a criação e a invenção de modos de vida como obras de arte por cada ser humano, onde quer que habite. Contudo, a contraposição a esse direito 
de vida e de morte parece implicar sempre a emergência de um enunciado subalterno situado entre a naturalização de uma fala (a do mundo das seduções fetichistas) e a memorização vigiada dos textos sagrados. Nem Obama, nem Osama, o que seria, pois?

\section{DOSTOIEVSKI E SEUS DUPLOS: ANTÍDOTOS À COMÉDIA STALINISTA}

Nos personagens de Dostoievski, produz-se muitas vezes algo bastante curioso, que pode dizer respeito a um pequeno detalhe. Geralmente, eles são muito agitados. Um personagem sai de casa, desce até a rua e diz: "Tânia, a mulher que amo, me pede ajuda. Vou correndo, ela morrerá se eu não for." Ele desce a escada e encontra um amigo, ou vê um cão atropelado, e esquece, esquece completamente que Tânia o espera, à beira da morte. Ele se põe a falar, cruza com outro camarada, vai até sua casa tomar chá e, de súbito, diz novamente: "Tânia me espera, é preciso que eu vá."

O que significa tudo isso? Em Dostoievski, os personagens são perpetuamente vítimas da urgência e, ao mesmo tempo em que eles são vítimas dessas urgências, que são questões de vida ou morte, eles sabem que há uma questão ainda mais urgente, embora não saibam qual. E é isso que os paralisa. Tudo se passa como se, na maior urgência - "É um incêndio, é preciso que eu vá" -, eles se dissessem: "Não, existe algo ainda mais urgente. Não moverei um dedo até saber do que se trata." É O idiota (romance de Dostoievski filmado por Kurosawa). É a fórmula de O idiota: "Veja, há um problema mais profundo. Qual problema, não saberia dizer ao certo. Mas me deixe. Tudo pode arder... É preciso encontrar esse problema mais urgente."

Gilles Deleuze, "O ato de criação". 


\section{Químico}

...Agora podemos constatar com segurança que

Dostoievski em estado puro é mortal.

Vendedor

E o que fazer?

Químico

Precisamos diluir.

Vendedor

Com o quê?

Químico (refletindo)

Bem, vamos tentar com Stephen King. E então veremos.

Vladímir Sorókin, Dostoiévski-Trip.

O excerto, acima, de "O ato de criação", ${ }^{11}$ é sobre o que é ter uma ideia num dado domínio do conhecimento - literatura, cinema, teatro, filosofia, ciências em geral - e expressá-la conforme a especificidade semiótica desses domínios, tendo por ponto de articulação, entre eles, o espaço e o tempo. Esse texto ganha outras dobras e redobras se o conectarmos com o romance The Master of Petersburg, de Coetzee, ${ }^{12}$ e com o texto dramático Dostoiévski-Trip, de Sorókin, ${ }^{13}$ e propusermos uma ideia, nesse sentido deleuziano, no âmbito da crítica cultural.

Se os personagens de Dostoievski implicam a dramatização de problemas urgentes, sempre mais urgentes, a ponto de se paralisarem, em busca de saber e estabelecer um problema ainda mais urgente, o que dizer sobre o estado de espírito daqueles sujeitos que, por força da ocidentalização do mundo, perderam sua língua, cultura, território 
e própria identidade? Qual a urgência de outra língua, cultura e território para a legião dos pobres em suas atividades e lutas comuns? Ou, de outra perspectiva, se o texto de Dostoievski é a duplicação e encenação de um limite, a que letargia, constitutiva das estruturas de subjetivação, esse texto se opõe?

Em Coetzee, o ser sem morada, que perambula de rua em rua, de cidade em cidade, de um extremo a outro das linhas constitutivas do humano, é o escritor. Em busca de saber o que teria acontecido com seu enteado de 20 e poucos anos, se teria suicidado ou sido assassinado por conta das lutas estudantis lideradas pelo anarquista Sergey Netchaiev (1847-1882), o escritor Dostoievski, em outubro de 1869, pouco mais de um ano antes da eclosão da Comuna de Paris, deixa sua (enésima) mulher na Alemanha em direção a São Petersburgo.

Recolhendo sinais, pistas, gestos, documentos que o levassem, de fato, a saber o que acontecera com seu enteado, o escritor-personagem se envolve com a dramatização e o questionamento do sentido de ser pai - pelo enteado ao longo dos mais de 10 anos de adoção; pela jovem esposa, que tinha quase a mesma idade de seu filho/enteado; pelos amigos e amigas do filho; pelo seu ferrenho adversário político, o líder anarquista mencionado; pela polícia, em suas investigações; e pelo próprio pai (personagem-escritor) com seus fantasmas patriarcais. Mas expõe também as fraturas ocidentais quanto ao lugar da criança na vida 
e no espírito do adulto, bem como em relação ao lugar do adulto na vida e no espírito de crianças e jovens.

Assim emerge uma primeira série de duplos: o fantasma do enteado-morto que assombra o padrasto em suas elucubrações metafísicas e o sujeito soberano que assalta o espírito do jovem Netchaiev em sua prática política, cuja regra $\mathrm{n}^{\circ} 1$ de seu catecismo revolucionário é: "O revolucionário é um homem que sacrificou sua vida. Não tem vínculos empregatícios, laços pessoais, sentimentos, cabrestos ou propriedades, nem mesmo um nome... Um único pensamento, uma única paixão: a revolução." ${ }^{14}$

Essas duas séries de duplos se multiplicam e se complexificam: das tensões fantasmáticas, o filho/enteado que se torna poeta e que escreve inspirado no pai/padrasto; a polícia que censura a escrita do filho/enteado como se fossem escritos de agitação do pai; o pai que escreve sob pressão de guerrilheiros para falsificar/encenar uma sentença de morte; um diário escrito pelo filho/enteado que perlabora a criança que teria sido entre a convivência com o pai biológico e o pai adotivo; a polícia que teria assassinado o filho revolucionário com suspeita do pai, um agitador por suas obras; um escritor que interroga a Deus como se fosse o seu duplo, o outro da escrita e condição da criação; do sujeito soberano que assalta o espírito do adolescente, $\mathrm{o}$ ataque aos pais pelo seu desprezo aos filhos ou a negação da criança que os habitaria; o desprezo aos intelectuais pelo apagamento da imagem do homem do povo 
que o encarnaria; a figuração do discurso revolucionário e materialista como se fosse a de um profeta e espiritualista; os apetrechos e performances para o rosto revolucionário entre a vida pública e a clandestina; a língua da revolução e a da física, química, mecânica e um pouco de medicina, pois um dos principais dispositivos dos revolucionários são os explosivos.

O ser sem morada, aqui, então, tem dois sentidos, um negativo, outro positivo. O negativo implica a morte do pai pelo filho rebelado ou a busca da criança, em si, por parte do adulto para que o sujeito ultrapasse a lógica de confinamento do patriarcado e se afirme como um ser humano, demasiadamente humano. O sentido positivo do ser sem morada implica a condição necessária do revolucionário.

Assim, uma primeira consequência dessa dramatização da primeira ordem de despejo (a do ser e sua morada) é responder ou criar as condições para a superação do estágio letárgico que envolve os processos de subjetivação do homem como imagem de Deus, bem como do homem como originário do macaco. Nem Deus nem macaco, mas um ser que, ainda por construir, deve estabelecer outros fundamentos a partir da encenação linguística e da cultura política.

Outra série de duplos mobilizada pelo Dostoievski, escritor-personagem de Coetzee, é a que envolve a nação como lugar geográfico e linguístico de um povo. Como lugar geográfico, a primeira resposta devastadora é: nem 
sob o crivo monárquico nem sob o republicano (a exemplo dos países europeus ou os até então existentes), mas um sentido de nação que se aproxime daquele defendido pelos anarquistas: uma miríade de comunas, associações de homens, mulheres e crianças articulados por uma cultura política como prática da liberdade, respeito e solidariedade.

Ao longo de toda a discussão entre o escritor-personagem Fyodor Mikhailovich e Nechaiev, em The Master of Petersburg, vislumbra-se uma nação russa, mas sem seu território dominado pela burguesia ou pelo Estado, independentemente de quais fossem suas formas de governo. Com esse perfil, o povo constitutivo desse Estado-nação não seriam nem os súditos do rei nem a massa de manobra para o "governo do povo, pelo povo e para o povo", mas um conjunto de coletivos organizados em comunas, associações, com autonomias para sua autogestão.

A língua ou o conjunto de línguas que dariam forma e que seriam os dispositivos de enunciação desses coletivos são uma espécie de língua menor que opera entre o discurso da burguesia e o da monarquia e articula associações e organizações internacionais do trabalho autogestionário.

O sentido jurídico-político desse Estado-nação resultaria na construção pública e politizada da lei e de suas implicações, de modo que o direito sempre fosse questionado e não apenas aplicado.

Assim, a segunda consequência dessa dramatização da segunda ordem de despejo (a do despejo cultural) é 
responder ou criar as condições para a superação do estágio letárgico que envolve o espírito político do homem, ainda perdido entre a lei religiosa que forma e conforma o discurso jurídico-político do Estado e a execução dessa lei que, contraditoriamente em nome do povo, pelo povo e para o povo, distribui os soberanos em toda rede de representação, além de conferir-lhes espaço para estarem, quando convier, acima da lei.

Por fim, a criação de um duplo mais radical e inquietante: "Eu escrevo perversões da verdade. Eu escolho o caminho torto e levar as crianças a locais escuros. Eu sigo a dança da caneta." ${ }^{15}$ Se uma precondição para o estabelecimento do espaço público da comuna é o agenciamento das marcas nos corpos e processos de subjetivação dos communards, pois sem isso não seria possível identificar e historicizar os instrumentos de tortura e seus autores e suas instituições, então o funcionamento da comuna como espaço de debate e desmontagem dos discursos de opressão e de poder reativos, com os encaminhamentos de seus decretos, formas de execução e estabelecimento do sentido e lugar da representação política (Vertretung), teria que ter uma dupla função: o poder de representação ser um espaço vazio, preenchível de acordo com as necessidades e os consensos locais, assim como o texto de "perversão da verdade" seria uma forma alternativa de esvaziamento da lei, da força de lei, a favor de que, através do torto, se organizem outras linhas retas diferenciais, paralelas, 
cruzadas como expressões do espaço e temporalidades das culturas políticas libertárias.

Assim, a terceira consequência dessa dramatização da terceira ordem de despejo (a do despejo linguístico articulado a um território da enunciação política) é responder ou criar as condições para a superação do estágio letárgico que envolve a indiferença relativa à perda do espaço público e sua língua revolucionária (e não apenas burocrática) de articulação.

Daí o espaço escuro - oferecido ou construído com os jovens ou como devir criança do adulto (não é à toa que os encontros do escritor-personagem com o fantasma de seu filho/enteado rebelado ou com o líder dos jovens russos se deem sempre em espaços clandestinos ou à meia-luz) - se constituir, em Dostoievski, como devir histórico do homem e seus processos revolucionários.

Contemporâneo do Coetzee sul-africano, o russo Vladímir Sorókin se apropria da matéria-prima, das máquinas e da fábrica de produção de duplos de Dostoievski, situando-os no "escuro" ou em trevas pós-soviéticas, para tratar de outra desterritorialização linguística, cultural, territorial e ontológica, bem como para responder a outras letargias.

Fazendo parte de um movimento pós-modernista diferencial russo aberto a partir de 1990, com a desagregação das repúblicas socialistas soviéticas, Sorókin, assim como Viktor Ierofiéiev, Mikhail Epstein, entre outros, vai reler 
a obra de escritores russos do quilate de Dostoievski como uma espécie de lugar arqueológico para se repensarem as ordens de despejo russo advindas com a "comédia stalinista" "encenada pelo regime soviético sobre um imenso palco da Eurásia e que teria despertado em seus espectadores sobreviventes (...) as impressões mais pessimistas e desesperançadas com relação à natureza humana”. ${ }^{16}$

Em três atos, a peça Dostoiévski-Trip apresenta-nos sete personagens (cinco homens e duas mulheres) sem nomes (apenas numerados) no primeiro ato; como se fossem personagens do romance $O$ idiota, no segundo ato; e de novo sem nomes, mas com breves biografias, no terceiro ato. Contracenam entre si, no primeiro ato, tratando da leitura de clássicos ocidentais como se fossem alguma espécie de narcótico com seus efeitos diversos, enquanto aguardam a chegada de um traficante - os livros (tornados pílulas) é como, disse, uma espécie de droga - que depois de muita demora, chega, e apresenta-lhes uma droga mais forte: o romance $O$ idiota.

Sob efeito dessa nova droga, subitamente todos os sete personagens se transformam em personagens do romance (Nastácia Filíppovna, Príncipe Mychkin, Ippolit, Liébedev, Gânia Ívolguin, Vária Ívolguina, Rogógin) e cada um começa uma série de delírios levada ao seu limite: um, com a queima deliberada de milhões de rublos numa lareira; outro, com a vontade de fecundação de todas as mulheres de países e continentes; outro, com os nervos de príncipe 
transformados em cordas de violinos tocadas pelo povo; outra, com mulheres lésbicas sendo arrastadas para uma espécie de cidade das mulheres; um outro, como devorador de esgotos. Isso até passar o efeito da droga e todos morrerem, no terceiro ato, com suas identidades numéricas, e depois dos relatos (entre eles) de suas biografias em formato minimalista - um perito em matar ratos que goza ao ser masturbado por um desconhecido numa viagem em trem lotado; outro que falha ao adestrar cachorro de caças, por isso é ameaçado de morte pelo avô; um que tinha o cu frouxo, relativo a um pinto pequeno; outro que tinha a perna azul; outro que fornicava com a própria mãe; outro que, durante o segundo ano de cerco dos nazistas, vivia no porão de uma casa em ruínas e que saía à cata de lixo para se alimentar, até terem (com seu irmão e outros entocados) a ideia de coletar bundas de cadáveres, transformá-las em almôndegas (alimento dos membros do comitê do Partido) que tinham a função de fazê-los vomitar e que eram trocadas por pão, cigarros etc. A peça é encerrada com um diálogo entre o vendedor e o químico: conteúdo da segunda epígrafe com que iniciamos este tópico.

Por que Dostoievski "em estado puro seria mortal" para a cultura política pós-soviética? Talvez uma resposta possível e plausível fosse: se antes da perseguição aos anarquistas, com a Segunda Internacional comunista e depois do fracasso da Comuna de Paris, os seus duplos, em perspectiva libertária, constituíam um lugar de exploração 
e pesquisa da alma russa, e, com a "engenharia das almas" proposta e posta em movimento pelo stalinismo, não só a literatura seria perseguida e perderia seu espaço de experimentação, mas o sentido de existência do ser humano bem como o próprio sentido de revolução e de revolucionário seriam anulados em nome da falsa emancipação que estruturava a "comédia stalinista".

Os duplos - dialéticos e paradoxais em perspectiva libertária - tornar-se-iam, em contextos pós-soviéticos, aprisionados pela (i)lógica do realismo socialista. Assim, em lugar do revolucionário sem nome, apaixonado pela revolução, ou do escritor sem morada, escrevendo epitáfios sobre os túmulos dos deuses mortos, temos apenas corpos drogados, catalogados para morrer, destituídos da potência de imaginar e de bioficcionalizar suas histórias.

Ora, se em Dostoievski-Trip, de Sorókin, a literatura é tratada como uma droga, fabricada por químicos, manipulada por traficantes e com a função, senão de matar, ao menos, de aliviar a fissura de seus usuários, a ordem de despejo ontológica, promovida pelo stalinismo, seria não apenas a do despejo do ser - a exemplo daquela promovida pelos colonizadores europeus ao ocuparem a América -, mas a da inviabilização da possibilidade de pensá-lo, representá-lo e dizê-lo.

Assim, a primeira consequência dessa dramatização da primeira ordem de despejo (a impossibilidade de bioficcionalizar o ser), em Sorókin, é responder ou criar as condições para a superação do estágio letárgico que 
envolve o espírito do materialista dialético, ou melhor, do stalinista tardio que, ao contrário de Lenin e Trotski, vetou a dialética ao criar uma literatura proletária em vez de explorar, de um ponto de vista socialista, a potência da literatura burguesa, além de inviabilizar a experimentação e a pesquisa acerca do fetichismo das mercadorias como condição para o estabelecimento de um horizonte de superação da luta de classes.

Se a exploração da potência da literatura, arte e cultura burguesas, por parte dos trabalhadores e oprimidos em seu processo de leitura e desmontagem dialética, foi inviabilizada pela literatura proletária, ou pelo realismo socialista, que impõe um modelo de trabalhador e de proletário que o fixa e o perpetua na história, além de suprimir a experimentação e a pesquisa acerca do fetichismo pela facilidade das "palavras de ordem" ou da "conceitualização" dos acontecimentos sem investigar sua emergência ou proveniência, então é o próprio território da possibilidade permanente da revolução, com seu imaginário sempre em movimento, suas seduções, entre outros afetos, que se esvai, que se esvazia, que encontra seu limite.

Assim, a segunda consequência dessa dramatização da segunda ordem de despejo (o território da imaginação revolucionária), em Sorókin, é responder ou criar as condições para a superação do estágio letárgico que envolve o retorno desenfreado do fetichismo das mercadorias num contexto em que os duplos e suas possibilidades estão aprisionados. 
O que resta, então? Sorókin propõe que, além de uma arqueologia da literatura clássica e pré-stalinista, experimente-se uma bricolagem da obra de Dostoievski com a do escritor de literatura de terror Stephen King, posto que aquele "em estado puro é mortal", e este, um produto para consumo da multidão. Aqui, por princípio, já teríamos um retorno em diferença da fabricação de duplos. Mas como perspectivar uma forma nesse sentido?

A terceira consequência dessa dramatização da terceira ordem de despejo (a língua duplicada), em Sorókin, é responder ou criar as condições para a superação do estágio letárgico que envolve o apego humano à fixação parasitária de um sentido único produzido tanto pela lógica do fetichismo quanto pela sua negação esquemática e mecanicista, apostando, assim, no gesto humano, demasiadamente humano, de dar forma e nomear aquilo que vem em relação a um estilo de vida comum fundado na multiplicidade dos encontros.

Se há uma lógica de constituição do duplo - fundada na perspectiva de um anarquismo libertário que dá forma a uma Rússia forte, ao contrário da lógica de aprisionamento desse duplo pela União das Repúblicas Socialistas Soviéticas em sua versão stalinista que, além de inviabilizar a literatura, desmonta e destrói a possibilidade do ser revolucionário -, então, não se trata mais de oporem-se anarquistas a marxistas (a menos que estes sejam stalinistas), mas de vislumbrarem-se as tarefas revolucionárias de uma comunidade que vem em suas formas duplicadas 
(se um tem por tradição incendiar as instituições, o outro ocupa parlamentos como espaços transitórios; se um investe todas as suas forças no perecimento do Estado e dos valores burgueses, o outro defende antes a ocupação do Estado e sua mudança de função como instituição de direito público, além de propor a incorporação e desapropriação da lógica burguesa por dentro de seus signos e fetiches) como condição de emergência de outros sujeitos políticos.

A pobreza absoluta, mais do que a condição humana submetida à ausência do básico para sobreviver, seria estar desprovido do exercício da linguagem para enunciar-se e abrir-se a historicidades. Daí o sentido da matéria-prima, das máquinas e das fábricas dostoievskianas.

\section{LIÇÕES DA CHINA}

Como não havia mais vaga no alojamento, tive de me acomodar num depósito de materiais, onde todas as noites um bando de ratos vinha me perturbar. Um deles até fez um ninho na minha mala e teve lá vários filhotes. Durante anos continuei achando que as minhas roupas e os meus lençóis ainda fediam a urina de rato. Achei no estoque uma dúzia de estátuas de gesso do presidente Mao e coloquei todas na porta de entrada e ao lado da minha cama, como vigias. Alguns amigos do círculo literário vinham me visitar. Quando, depois de contornar todas as barreiras de vigilância do Exército, chegavam em meu quarto e viam o que eu tinha feito, diziam que eu era o cara mais poderoso da China, porque tinha como vigias particulares uma dúzia de presidentes Mao.

Mo Yan, Mudança. 
Para o escritor que escolhe a literatura de testemunho, as coisas são, obviamente, bem claras: ele usa personagens e fatos reais ou usa sua própria experiência, e sua criação literária é, em última análise, limitada por esse contrato que ele estabelece consigo. E se aceita as regras e vai em busca do real, a presença ou não disto torna-se o juízo de valor que o coloca acima de tudo.

Em comparação com a história, o testemunho da literatura é sempre mais profundo. (...) Além disso, é passível de a realidade ser escondida pela história? Quando o escritor parte em busca da realidade oculta da história, restaura a memória perdida, mais do que exumar documentos históricos frios, é mais importante contar com a experiência de vida, a sua própria ou a de seus parentes, e então este tipo de testemunho naturalmente traz a marca da autobiografia e da biografia.

Digamos adeus à ideologia... digamos adeus ao historicismo rígido... digamos adeus à subversão da linguagem.

Gao Xingjian, Le témoignage de la littérature, tradução minha.

A partir de três livros seminais contemporâneos sobre a China - Zhou Enlai: o revolucionário perfeito, de Gao Wenqian, ${ }^{17}$ Mudança, de Mo Yan, ${ }^{18}$ e Le témoignage de la littérature, de Gao Xingjian ${ }^{19}$-, podemos tematizar outras noções relevantes sobre a luta desarmada dos subalternos. No primeiro, a imagem do Estado como uma construção cultural levada ao limite; no segundo, como sobreviver à revolução cultural, num contexto autoritário, fazendo 
do silêncio uma forma de expressão; e, finalmente, no terceiro, como estabelecer o corte entre a literatura e a política (esta com suas prescrições e vontade de controlar) como condição para que aquela seja um modo radical de pesquisa do real e do sentimento humano.

A biografia política de Zhou Enlai (1898-1976), primeiro-ministro chinês durante a era Mao Zedong (19491976), escrita por Wenqian, mais do que apresentar a trajetória política de um homem público (de sua formação política às organizações de eventos e atos, públicos e clandestinos, próprios da vida revolucionária, passando pelas tarefas burocráticas aos modos de resistir e sobreviver aos golpes baixos do cotidiano da vida política), é um jogo de cartas sobre o teatro da vida política da China comunista, bem como sobre o movimento e o uso do Estado como instituição de direito privado (em nome do Estado como de direito público e popular).

As formas articuladas por Zhou Enlai e todo o conjunto de políticos filiados ao Partido Comunista Chinês, desde sua fundação em 1921, demonstram como a estrutura do Estado foi construída tanto para superar aquele modelo de Estado democrático-burguês, instituído uma década atrás (em 1911), quanto para superar, também, o modelo estatal existente na União Soviética stalinista. Entre o Estado democrático-burguês e o soviético stalinista ou mesmo krucheviniano, propõem-se as Comunas Rurais Populares, inspiradas na Comuna de Paris $^{20}$ ou nas soviéticas 
anteriores ao stalinismo, tendo os camponeses - não os operários e os militares - como atores principais.

Para chegar a esse ponto, vale relembrar algumas imagens do movimento político revolucionário na China. Primeiramente, destaca-se que sua revolução democrático-burguesa, responsável por destituir do poder uma dinastia milenar, se deu em 1911, para daí, sob um viés mais libertário e anarquista, ir se formando uma cultura nacionalista. Em segundo lugar, a eclosão do Movimento de Quatro de Maio de 1919, em consequência da Conferência de Paz, em Paris, do início daquele ano, que passa os territórios chineses, ocupados pelos alemães na província de Shandong, para os japoneses.

Estudantes e trabalhadores de toda a China que, até então, eram simpáticos às democracias ocidentais passam não só a confrontarem e demolirem os valores da cultura japonesa, principalmente os comerciais, existentes na China, mas a aderirem, cada vez mais, à perspectiva socialista recém-instalada na União Soviética. Em terceiro lugar, com a criação do Partido Comunista Chinês, em 1921, e a disseminação dos estudos marxistas, entre os círculos intelectuais, os trabalhadores e, principalmente, as massas camponesas empreendem um conjunto de lutas, por toda a China, a ponto de, em 1927, quase derrubar a burguesia e implantar o socialismo chinês, não fosse o apoio de Stalin aos nacionalistas. 
O apoio de Stalin aos nacionalistas, gerando massacres de trabalhadores e camponeses em várias regiões importantes da China, implicou um importante divisor de águas: Mao Tse-tung não só escapa, com seu exército de camponeses, mas reinventa a teoria da revolução socialista, agora com ênfase nos camponeses, na luta de guerrilha, e com perspectiva econômica não economicista, mas fundada no desenvolvimento cultural e econômico-diferencial das Comunas Rurais Populares.

Assim, proprietários de terras, camponeses ricos, camponeses pobres e trabalhadores sem terra, sob a orientação do Partido Comunista Chinês, não apenas derrubaram os nacionalistas em 1949, mas, ao longo de mais ou menos 30 anos (1949-1979), constituíram a base da reforma agrária e a instalação das Comunas Rurais Populares, cuja imagem geral seria: 1) a geração de pequenas propriedades; 2) entre 1949 e 1957, um reagrupamento, em etapas sucessivas, passando das cooperativas semissocialistas, em 1953, para as cooperativas socialistas ou coletivização, em 1955, formando, assim, unidades coletivas cada vez mais importantes; 3) a constituição da comuna num organismo no qual estivessem reunidas as atividades da agricultura, indústria, comércio, crédito, milícia, escola. Eram as chamadas "fazendas do Estado". Uma comuna era constituída por 30 cooperativas socialistas, agregando cerca de 5 mil famílias, 4 mil hectares de terras produtivas e 9 mil trabalhadores. 
Até 1964, havia, por toda a China, cerca de $70 \mathrm{mil}$ comunas, cuja unidade econômica era constituída pelas brigadas. Estas consistiam em equipes de produção, à maneira das cooperativas semissocialistas, onde cada uma assumia mais ou menos 22 hectares de terras produtivas.

Supunha-se que viveram aí de 26 a 28 famílias e 50 trabalhadores. As diferenças principais dessas Comunas Rurais Populares para a coletivização soviética eram: a) a primeira se deu sem muitos conflitos, ao contrário da segunda, que se deu em meio a uma guerra civil; b) desapropriadas as terras, em nome do Estado, na China, os interessados se organizavam e aderiam ao processo comunal, pagando alguma taxa por isso e com algum direito na produção, conforme sua necessidade, resultante desse trabalho coletivo - na União Soviética, tudo era financiado e controlado pelo Estado -; c) a autoridade político-administrativa da Comuna Rural Popular concentra o poder da ordem, da lei e do partido, por alguém que emerge das bases camponesas; na União Soviética, tudo passa por uma burocracia técnica, com seu controle e prescrições.

Se cada comuna (das 70 mil disseminadas pela China) podia concentrar e explorar as mais diferentes atividades de produção - estas sempre fomentadas, induzidas ou impostas pelo governo - e considerando, ainda, que em 1964 a China já possuía 700 milhões de habitantes, então não só se podia vislumbrar daí uma potência econômica no futuro - como muitos analistas já o faziam, apesar do 
desastre de alguns planos econômico-culturais, como o Grande Salto para Frente (1958-1962) -, mas também uma verdadeira virada cultural envolvendo a comunidade camponesa.

Sem entrar no mérito da noção de exploração do trabalho de uma multidão camponesa, em parte essa riqueza da China deriva de uma lógica, aqui descrita em linhas gerais, que combina: um corte no latifúndio, pondo em seu lugar as pequenas propriedades; uma suspensão, consistente, da possibilidade de exploração de mão de obra camponesa barata pelas empresas burguesas e multinacionais; um estímulo estatal à produção da riqueza nacional a partir de seus próprios recursos e organizações de trabalho; a diversidade de produção implicando uma complexificação das habilidades trabalhistas, bem como a abertura de inumeráveis perspectivas para o mundo do trabalho e o mercado de bens e consumos.

A virada cultural camponesa viria, então, no meu ponto de vista, não da Revolução Cultural Chinesa, que, segundo Gao Wenqian, foi um movimento criado por Mao, sua mulher (Jian Qing) e a chamada Camarilha dos Quatro (Jian Qing, Wang Hongwen, Zhang Chunqiao e Yao Wenyuan) para impedir o surgimento de um "Kruchev Chinês": aquele(a) que usaria os dispositivos do Estado, da arte e da cultura para denunciar os seus crimes, bem como para mudar a orientação da política comunista chinesa, 
abrindo-a à lógica do desenvolvimentismo econômico e ao mercado capitalista.

Embora faça algum sentido a ideia - que atravessa a Revolução Cultural Chinesa - de que camponeses possam reeducar os intelectuais - e os alunos, os seus professores -, sobretudo no contexto ocidental e oriental de imposição e hierarquização do saber como forma reativa de poder, a primeira lição chinesa para o resto do mundo e, principalmente, para o Brasil é: se apropriar das linhas de força da Comuna de Paris para esvaziar a "comédia stalinista" e socializar aos camponeses os dispositivos para o entendimento e o funcionamento da máquina estatal, sem que tais camponeses devessem, necessariamente, ter e/ou fazer uso de uma teoria do Estado.

As cozinhas e lavanderias coletivas, creches comunitárias, entre outras dezenas de milhares de exemplos de espaços coletivos que implodiam os hábitos das famílias camponesas e as colocavam no limiar entre o espaço público e o privado, ou, ainda, a reeducação dos intelectuais em trabalhos no campo, teriam não só constituído um entre-lugar para experiências notáveis quando da passagem de pessoas-objetos a pessoas-sujeitos, mas, principalmente, um laboratório para outro tipo de expressão política fundada em espaços, nesses casos também autoritários e permanentemente vigiados.

Em Mudança, relato autobiográfico do escritor Mo Yan (seu nome verdadeiro é Guan Moye), premiado com o Nobel em 2012, temos uma imagem precisa dessa expressão 
política - entre o completo silêncio e a astúcia dos gestos - que emerge em contexto fora dos padrões da democracia burguesa na qual se pode falar de tudo, contanto que não se mude nada, segundo István Mészáros em Para além do capital: rumo a uma teoria da transição. ${ }^{21}$

Mo Yan, que significa "não fale" (advertências de sua mãe, quando o escritor tinha 10 anos de idade, quanto a dizer no espaço público o que acontecia em casa), começa seu livro de memórias relatando os motivos por que fora expulso da escola, em 1969, aos 14 anos: botou, segundo conversa de corredores, o apelido de Sapo Boca Grande no professor de Matemática, Liu Tianguang, que, além de filho de mártir, era vice-diretor do Comitê Revolucionário de sua Escola Rural.

Além de expulsão formal, ainda levou socos, pontapés, puxões de orelha e toda sorte de violência física e moral tanto por parte do professor quanto pelos colegas mais velhos, aliados daquele, pois o menino expulso insistia em frequentar a escola, senão para estudar, ao menos para assistir às partidas de pingue-pongue jogadas pelas meninas "donas de pele de porcelana", filhas dos funcionários da fazenda do Estado e oriundas de famílias ricas.

Ao longo de todo o relato autobiográfico de Mo Yan, nota-se a construção de uma performance que envolve a figura de um camponês que não vivia no interior de uma Comuna Rural Popular - a qual, como já dissemos, não era estendida universalmente a todos os chineses, mas se dava por adesão dos interessados. Como sua família não 
fazia parte dessa estrutura, tudo parecia ainda mais difícil: 1) em 1969, a expulsão da escola; 2) entre 1969 e 1976, em vez do trabalho duro na lavoura, um trabalho temporário numa fábrica de processamento de algodão em sua aldeia (Gaomi); 3) entre 1973 e 1976, decide tentar sua sorte no Exército de Libertação Popular, em vez da universidade, uma vez que, para isso, havia demasiada concorrência nas comunas, com privilégios para os filhos dos dirigentes; 4) em 1976, uma vez no Exército e, depois de muitas tentativas, situado numa posição de último escalão (vigia e lavrador), se dedica à literatura por sua própria conta; 5) entre 1978 e 1982, observado por seus superiores, é chamado para concorrer a uma vaga no Instituto do Exército de Libertação Popular, de sua seção/estação, desafio que encara sozinho com estudos autodidáticos que, infelizmente, são frustrados por essa vaga mencionada ser retirada de pauta, embora, por esses aprendizados autodidáticos - de trigonometria, por exemplo -, tenha conseguido o cargo de professor no batalhão de treinamento de Boading e sido nomeado oficial comissionado de treinamento; 6) entre 1981 e 1984, publica seus primeiros textos em revistas de grande circulação e é admitido pelo Departamento de Literatura do Instituto de Artes do Exército de Libertação Popular; 7) entre 1987 e 2009, tem seu romance Sorgo vermelho filmado/adaptado para o cinema pelo diretor Zhang Yimou, realiza mestrado na Universidade de Pedagogia de Pequim e no Instituto Lu Xun de Literatura e participa 
da política cultural chinesa, avaliando obras e projetos populares, a exemplo da criação da companhia juvenil de maoqiang, um desdobramento da ópera maoqiang, transformada em patrimônio cultural da China; 8) realiza o sonho de seu pai, que seria o de se tornar um membro do Partido Comunista Chinês.

Nota-se na construção de sua performance autobiográfica um périplo condizente com o que defendemos, aqui, como expressão política tramada entre o silêncio e a astúcia dos gestos: o menino de 14 anos que, através da linguagem de corredores (sem confronto direto), afronta o professor, representante do Estado na escola, e por isso é expulso. Durante parte da adolescência trabalha numa pequena fábrica de processamento de algodão, mas, nas horas vagas, dedica-se à leitura dos clássicos chineses e à prática de escrever cartas para colegas de trabalho analfabetos, a ponto de ser chamado de "intelectual" em seu ambiente. Graças a esse distanciamento que a literatura promove, consegue ler sua realidade imediata e enfrentar os dispositivos estatais (a comuna, o exército, a escola, o partido) sem confrontá-los e se apropriando do que eles dispunham à margem, e como restos.

Foi assim que, como vigia e pedreiro, na Unidade de Inteligência do Ministério da Defesa, na verdade "uma estação de radiogoniometria prestes a ser desativada", começou a escrever seus primeiros contos, ampliar sua leitura dos clássicos, assinar algumas revistas importantes e 
dedicar-se a estudos autodidáticos, visando a sua ascensão profissional.

Sua admissão no Departamento de Literatura do Instituto de Artes do Exército de Libertação Popular indica, ao menos, duas cenas estético-políticas relevantes: a primeira, sobre o papel da arte na constituição do sistema comunista chinês; a segunda, em vez de um lugar de controle, uma dobra e um ponto de conexão libertária. Assim, o estilo autobiográfico de Mo Yan presente em Mudança, mas também em seus contos iniciais, a exemplo de "Uma corrida trinta anos atrás", "Mamãe", "O divórcio", "Noite de chuva na primavera", "O soldado feio", entre outros, é uma estratégia discursiva que lhe permite ver a si mesmo e se constituir como sujeito num contexto de exacerbação coletivista e, ao mesmo tempo, oferecer-lhe um antídoto contra uma espécie de escrita fundada na imaginação esquizofrênica.

Assim, uma segunda lição da China seria: nem realismo socialista, em que a arte seria controlada pelo Partido Comunista e pelo Estado para servir-lhes de propaganda, nem experimentalismo descabelado, em que a arte, além de levada ao limite em seus significantes, seria o lugar da dilaceração do ser e, por consequência, a impossibilidade de se afirmar como sujeito da experiência, mas através de um controle dos processos de imaginação criadora, por parte do sujeito communard, reciclar os restos, as ruínas, que transbordam dos/nos ambientes e situações 
autoritárias, num arranjo favorável a uma experiência de vida que, deliberadamente, escolhe não cutucar o cão com vara curta.

Em Le témoignage de la littérature, Gao Xingjian cutuca o cão, mas com outros recursos, abrindo mão dos "ismos" que atravessam a literatura e o pensamento ocidental, fazendo de sua "reeducação no campo" um modo radical de liberar a literatura da política e operando na literatura um laboratório de pesquisa do real e do sentimento humano. Com isso estabelece condições indispensáveis tanto para se ocupar e deslocar o latifúndio estético de artistas e escritores, ocidentais ou orientais, quanto para afirmar a precariedade do escritor como um sujeito que deve fazer da experiência da/na linguagem um modo de afrontar a sociedade e suas representações.

Bem mais velho que Mo Yan (este de 1955, aquele de 1940), e com origem social diferente, Gao Xingjian era filho de banqueiro e de atriz amadora. Nasceu em Ganzhou, província sul oriental de Jiangxi, e estudou francês no Instituto de Línguas Estrangeiras de Pequim, diplomando-se aos 22 anos e tendo concentrado seus estudos de formação a partir da obra de Antonin Artaud, Samuel Beckett, Bertold Brecht e Eugène Ionesco. Além de escritor, também é dramaturgo, pintor, desenhista, crítico literário e o primeiro chinês a ganhar o Prêmio Nobel de Literatura, em 2000, mas morando em Paris, onde se exilou 
em 1989, quando do massacre dos estudantes na Praça da Paz Celestial.

Com esse perfil, qual a sua condição subalterna e qual o sentido de sua luta desarmada? Um olhar não burguês ocidental, nem stalinista tardio, mas fundado numa perspectiva crítico-cultural anarquista, define sua condição subalterna a partir do lugar e posição que a cultura e o modo de vida burguês ou de classe média alta assumem ou são submetidos num contexto comunista de apropriação das matérias-primas, das máquinas e das fábricas e/ou no caso chinês de proliferação de Comunas Rurais Populares.

Mudam-se, nesse processo de transição revolucionária, não só o lugar do jogo político e o estabelecimento de suas regras, normas e leis, mas os espaços de enunciação dos sujeitos que compunham a classe dominante.

O sentido de sua luta desarmada, e como subalterno, emerge nos vários espaços de "reeducação no campo" ou nas comunas rurais camponesas, a que várias vezes foi forçado a frequentar, entre 1966 e 1976. Acrescenta-se, ainda, que Gao Xingjian só rompe com o Partido Comunista Chinês por conta do massacre dos estudantes na Praça da Paz Celestial, no final da década de 1980.

Dito isso, sua crítica aos "ismos" do Ocidente, bem como ao confucionismo chinês, se deve, no primeiro caso, à vontade demiúrgica dos escritores e seu espírito latifundiário (a posse de uma língua e sua experimentação pela experimentação, a prescrição de um gosto, a função 
de propaganda política do Estado, o ser porta-voz de um humanismo suspeito) e, no segundo, à simplificação ou facilitação redutora dos complexos processos de construção da subjetividade humana. Para combater isso, elege como seus precursores os autores de sua formação, a exemplo de Franz Kafka e Fernando Pessoa, além de escritores chineses clássicos, tais como Cao Xueqin, Li Qingzhao, Li Bai, Han Yu, Jin Shengtan, Shi Nai'an, entre outros.

O “ismo", para Gao Xingjian, necessariamente, está associado a um "ter" que implica o engajamento do escritor na política do Estado, portanto, uma desapropriação da literatura como recurso individual de cada escritor para escrever-se nas tramas de desvelamento/reconstrução do ser.

Apropriar-se da língua para se reinventar, se refazer, se reconstruir das violências físicas e simbólicas é tarefa do escritor comprometido com uma espécie de reforma/ revolução agrária desse imenso latifúndio que é a literatura.

Uma oposição possível, portanto, a esse "ismo", avoir [ter], seria uma espécie de ne pas avoir de -isme [não ter -ismo], o que, segundo o autor, "isso não consiste senão em falar sem um ponto de partida e sem ponto de chegada, em falar sem chegar a qualquer conclusão". ${ }^{22}$ Assim, nem ne pas avoir de -isme, como um agregado da língua, da linguagem e do Estado, nem pensamento filosófico acerca do être [ser], mas um laboratório da língua a que cada escritor tem direito, como um homem comum, para pesquisar os sentimentos humanos. 
Partir de sua própria experiência ou de personagens e fatos reais, implicando com isso uma "não finalidade", que seria a pesquisa dos sentimentos humanos, antes expõe o tratamento que os sistemas de dominação vêm dando à vida na terra e, ainda, estabelece um contrassenso de alta voltagem: investigar os sentimentos humanos provocados por cada um de seus órgãos de sentidos (o olhar, o cheirar, o degustar, o ouvir, o tocar) que tanto podem ter sido mascarados pela história e suas formas de representação quanto terem tido por fundamento a lógica do fetichismo da mercadoria. Em seu laboratório, e em sua solidão necessária, o escritor, como um homem comum, sem nenhum poder extraordinário, reencena seus sentimentos, bem como de outros seres humanos, adotando uma lógica do absurdo, como condição de emergência de outra noção de política.

Por todo o livro, antes mencionado, há uma ênfase na recuperação da potência da literatura, a seu ver destruída ou em via de destruição tanto pela prescrição do gosto estabelecida pela crítica e teoria literária, quanto pelo engajamento dos escritores como funcionários do Estado e do capital. Quando foi obrigado a trabalhos forçados ou à "reeducação" em Comunas Rurais Populares, entre 1966 e 1976, não só teve que incinerar sua biblioteca, mas todos os seus inéditos - daí, provavelmente, uma imagem-limite da recusa do vínculo da literatura como propaganda de um Estado ou de um partido. 
Outro paradigma para se produzir literatura, nessas condições, só poderia emergir como exercício do silêncio, crítica radical às formas de controle da expressão e antídoto para se pacificar as dores e sofrimentos. É por isso que Gao Xingjian tem razão ao criticar as estratégias de subjetivação de grande parte da literatura ocidental, bem como da literatura oriental, fundada nas linhas gerais do confucionismo, por tais estratégias não apenas estarem muito distantes da vivência humana num regime ou numa situação de exceção, mas, de tão comprometidas com os aparelhos de Estado, não oferecerem alternativas - como a tematização do absurdo, por exemplo - a escritores e leitores quanto à reinvenção de si mesmos a partir de outra língua, dobrável, perscrutável, exercitável em laboratório, e que, além de feridas e histórias de vida, possam encontrar suas tocas contra esses aparelhos de captura.

Eis, aqui, uma terceira lição da China: o escritor, o professor ou o intelectual, forçados a abrir mão de sua subjetividade em nome de um coletivo como dispositivo de Estado, não só usarem diferencialmente a literatura e sua força de resistência, mas, ao separarem a literatura de seu compromisso com políticas do Estado, fazer dela uma forma de pesquisa do real e do sentido humano, em tempos de exceção e barbárie.

Com a Revolução Soviética, sobretudo com o stalinismo, tivemos, no início dos anos de 1930, o estabelecimento de um sistema de controle para a arte, desmontando, com 
isso, as experiências formais e seus impulsos libertários no plano da experiência social. Tivemos também o estabelecimento de um paradigma utópico para os artistas que, então, aderem ao stalinismo como promessa de emancipação da humanidade. Com a Revolução Chinesa, demonstramos, aqui, não apenas que ela implicou um desvio do stalinismo, ao adotar um modo de governo constituído por Comunas Rurais Camponesas e Populares - mais próximo dos primeiros anos da Revolução Soviética, sob o comando de Lenin e Trotski - e ao mobilizar elementos teóricos da Comuna de Paris, mas também, no plano literário e cultural, através de seus escritores mais representativos, que soube conjugar elementos fundamentais da vanguarda estética ocidental, criticar e deslocar o realismo socialista e propor novas exigências para os escritores, em suas tarefas de reler e reescrever o Estado de exceção que impregnou a experiência revolucionária no Oriente e constituiu o modo de ser das chamadas democracias ocidentais contemporâneas.

Em suma, é possível flagrar, a partir dos tópicos deste capítulo, que a literatura, a língua, a obra de arte em geral, embora possam ser desviadas a favor das forças de dominação - e apenas por seu intermédio -, são capazes de desarmar o mundo por um instante, dramatizar suas dores e convocar a todos para um debate, ou mais radicalmente: estimular, paciente e solitariamente, o trabalho clandestino de exploração e expressão dos sentimentos humanos, em busca de vida, de realização de sonhos e de afirmação da existência como uma poética. 
Se é através do campo linguístico-literário e da obra de arte que podemos reter, por um instante, a barbárie do mundo e perguntar por que não outra experiência em lugar dessa barbárie, não seria o caso de revermos o sentido de nossa transcendência pautada, até agora, na teologia, que ainda perdura nos modos de composição e funcionamento do Estado, e na matemática e biologia, como critérios quase absolutos de se fazer ciência?

E se fizermos uma arqueologia da descoberta do signo, pela linguística, e sua abertura do significante, pela literatura, em fins de 1870, e acompanharmos sua repercussão nas ciências humanas e suas viradas linguístico-literárias, ao longo do século XX, como pensar a teologia e a matemática apenas como formas discursivas? E, sendo formas discursivas, quais têm sido o seu lugar nas práticas institucionais e na corrida armamentista?

Seria possível, ao gênero humano e seu espírito belicoso, discernir em meio à guerra os ruídos sutis de seu próprio canto ou do canto de um outro homem por vir? Pois é assim que Benveniste anuncia:

Três anos após a morte de Saussure aparecia o Cours de linguistique générale, redigido por Bally e Séchehaye segundo notas dos estudantes. Em 1916, no meio do retinir das armas, quem poderia preocupar-se com um trabalho de linguística? Nunca foi mais verdadeira a palavra de Nietzsche de que os grandes acontecimentos chegam sobre patas de pombos. ${ }^{23}$ 


\section{ROTEIROS DE CRÍTICA CULTURAL}

Provavelmente não há muito o que esperar de uma teoria que defenda o argumento ou a palavra de ordem de que o materialismo social concernente a um processo de transvalorações culturais, sociais e políticas possa se dar mesmo com a ausência de frases. ${ }^{1}$ Não é com discursos que se transforma o mundo, mas com ações efetivas, principalmente se associadas ao quebra-quebra de uma ordem burguesa para a instalação de uma nova ordem socialista.

Ora, aprendemos com a linguística, e com seu desdobramento semiológico, que a língua é um fenômeno social e que, por isso mesmo, pressupõe a existência de falantes para nomear o mundo e pôr em movimento a relação entre palavras e coisas - o circuito dos enunciados e das enunciações - sob diversas lógicas e fonologias. Assim, na suspensão de todas as frases em atos revolucionários existe uma ordem de significantes que supõe uma multiplicidade de significados subjacentes aos mais diferentes enunciados e enunciações, ainda que em forma de figuras empunhando suas armas, o coração batendo de desespero 
ou de alegria, o sangue agitando veias e artérias e a geometria das cidades se dobrando em fumaça.

A questão contemporânea para a revolução cultural, sob uma perspectiva materialista, não é mais pressupor que há uma superestrutura determinada por uma infraestrutura econômica, mas, se há ao menos uma cabeça que pensa e que não deixa determinar-se pelas forças econômicas, então todas as cabeças, em tese, não se deixariam determinar por quaisquer formas de dominação, ou mais que isso: cada ser humano, pobre e explorado, pode, em seu local de exploração, dispor desses signos e avaliar suas formas e ocorrências - quem os produz, sob que vontade - e movimentar uma outra semiótica de deslocamento e reversão.

Uma primeira consequência que tiramos daqui é: todo o discurso revolucionário fundado no mecanicismo do século XIX não apenas é ignorante quanto aos seus significantes, mas trava o espírito revolucionário quanto à leitura e semiotização das dobras e façanhas do capitalismo e seus sistemas de fetichização.

Se essa constatação é verdadeira, e se a luta deve continuar sem armas e sem conformismo lambe-botas, então talvez seja o caso de reunirmos os dados para composição de uma outra epistemologia da revolução - e não temos um ponto de partida mais radical do que o do campo linguístico-literário. Primeiro, por ser determinante na virada linguístico-literária das ciências humanas, ao longo de todo o século XX, percebemos a consequente suspensão, 
ainda que provisória, da matemática e da teologia como critério científico e político; segundo, por nos permitir mapear, nos principais autores das ciências humanas do século XX, bem como em seus comentadores, os usos das principais descobertas e experimentações da linguística e da literatura, além do conjunto de problemas e questões sobre o sentido de revolução e de reinvenção do ser humano e suas formas de sociabilidade e de produção simbólica libertárias; terceiro, pela capacidade de acolhimento, no campo linguístico-literário, dessas descobertas nas ciências humanas, criarmos uma zona autônoma de produção de um trabalho científico, político e estético radicalmente multidisciplinar e democrático.

\section{BELETRISMO COMO SINÔNIMO DE CONFORMISMO E COOPTAÇÃO}

Uma imagem de beletrismo entre nós bastante difundida é a de "arte pela arte", que o parnasianismo à brasileira engendrou e que marcou o corpo da cultura. Isso foi tão fecundo que deixou de ser um procedimento artístico conservador na periferia do capitalismo para, contemporaneamente, tornar-se quase um crivo cultural.

Em "A democratização no Brasil (1979-1981): cultura versus arte", ${ }^{2}$ Silviano Santiago argumenta que belles-lettres é também sinônimo do alto modernismo que perdeu seu poder de contestação, seja porque o tema da exploração do 
homem pelo homem não contempla a produção cultural minoritária e suas novas frentes de luta, seja porque o leitor comum teria sido excluído pela alta especialização da linguagem, então acessível apenas aos vanguardistas e seus pares (escritores, críticos, historiadores, teóricos e intelectuais).

A cultura então ascende porque não apenas os poetas e escritores marginais assassinam Mallarmé ${ }^{3}$ e saem pichando os muros da cidade com o sangue da poesia, mas também porque não interessa mais a noção de literariedade que atravessa o alto texto literário, agora transformada num banquete antropofágico: cada leitor agora pode recolher uma cena como um gesto de profanação e reinvenção de si, do mesmo modo que o crítico literário ou cultural não deverá mais estar preocupado apenas com estruturas de linguagem, mas com o que essa estrutura teria recalcado em termos de imagem cultural e sua expressão de sujeitos e historicidades.

Em “A praga do beletrismo", 4 e em certa medida em oposição a Silviano Santiago, Luiz Costa Lima caracteriza essa "praga" que devasta o campo linguístico-literário como entulhado de disciplinas, fraco filosoficamente, ignorante quanto à sua potência e com funcionamento semelhante ao de um curso de pedagogia, e vai além: toda a abordagem multicultural é também beletrista.

Ao se compararem as duas perspectivas, pode-se, de um lado, vislumbrar em Silviano Santiago uma espécie de "desembaraçamento do marxismo", em linha foucaultiana, 
mas que parece confundir marxismo com stalinismo, ou, ao menos, que não considera a força emergente do marxismo contemporâneo. De outro, em Luiz Costa Lima, acredita-se ainda numa potência da vanguarda estética, sua vontade de ruptura, seus espaços de experimentação formal, que parecem, contraditoriamente, abolir ou não ter nenhuma esperança nas instituições literárias: escolas, universidades, governos, além, claro, de toda cadeia produtiva derivada do linguístico-literário.

Entretanto, um olhar mais arqueológico para a emergência das belles-lettres pode apontar linhas gerais para um outro roteiro de crítica cultural. Comecemos com uma pergunta: não teriam sido as belles-lettres uma tentativa de cooptação do campo linguístico-literário pelo Estado, em conúbio com o capital, pós-Comuna de Paris em 1871? Em uma carta aberta aos artistas da França e países vizinhos, datada de 18 de março de 1871, momento em que se instala a Comuna em Paris, Gustave Courbet ${ }^{5}$ conclama e convida todos os artistas para numa assembleia discutir e definir um decreto communard para artes.

Entre os principais motivos, temos: 1) a elaboração de uma proposta de "reorganização da Administração das Belas-Artes", com os objetivos de combater a arte aristocrática e teocrática, sua abordagem feudal, e de combater as academias e institutos, pois até então só promoveram arte convencional e banal, distribuíram privilégios, suprimiram a espontaneidade e atrofiaram o espírito e a mente do artista, através da perpetuação da arte pela arte, sem 
caráter, nem convicção; 2) a discussão em assembleia de artistas sobre planos, projetos e ideias para uma reorganização da arte, seus interesses materiais, necessidades, filosofia e seu papel na reconstrução física e moral do homem para a experiência democrática; 3 ) a definição de um movimento para salvar a nação de um abismo. Como um símbolo dessa intensa atividade política, promovese a derrubada da Coluna Vendôme, em homenagem a Napoleão, então produzida com o chumbo fundido de 1.200 canhões europeus, tomados durante as conquistas da chamada revolução democrático-burguesa na França.

Mesmo sem entrar no mérito de que a Comuna só durou 72 dias - 26 de março a 28 de maio - e que, portanto, acabou levando consigo a sua concepção de arte, pode-se extrair dessa carta de Gustave Courbet o seguinte: como crítica ao controle da obra de arte por parte do Estado, através de academias e institutos, não basta uma reorganização da arte, em termos de interesses materiais (isto é, semióticos, formais) e de sua filosofia, mas, necessariamente, uma reorganização da sua administração para se repensar e criar outras instituições comprometidas com a abertura do espírito e mente do artista, bem como com a construção de uma sociedade democrática.

Se a literatura é uma arte da palavra, então as propostas da Comuna têm tudo a ver com ela. Fiquemos com dois exemplos extemporâneos: Os sertões, ${ }^{6}$ de Euclides da Cunha, e As flores do mal, de Charles Baudelaire. ${ }^{7}$ Em Euclides, o povo do sertão e sua luta toma a obra de 
assalto, mesmo contra a vontade do escritor e seu aprisionamento formal e ideológico. Em Baudelaire, não caberia apenas uma crítica ao Estado e suas noções e práticas de política pública para as artes, mas assumir o fetichismo da mercadoria, mudar o uso do texto literário, apostando no seu estranhamento, no choque e no corte, como condição de enfrentamento do capitalismo, em sua fase superior e imperialista.

Na mesma década da Comuna, precisamente em 1879, surge, ainda, um livro com espírito de revolução communard. Escrito por Ferdinand de Saussure, aos 21 anos, trata-se do Mémoire sur le système primitif des voyelles dans les langues indo-européennes. ${ }^{8}$ Ao perguntar sobre a forma e sentido do "a" nas línguas indo-europeias e, depois de rigorosa pesquisa, chegar à conclusão de que há, diacrônica e sincronicamente, uma multiplicidade de realizações fônicas, acompanhadas, também, de uma multiplicidade de imagens acústicas, constata, para além disso, dois problemas cruciais e incontornáveis para a epistemologia linguística de seu tempo: a realização fônica de [a], [ã], [ae], [ao], acompanhada de sua respectiva imagem acústica, é inseparável e implica, radicalmente, uma duplicidade paradoxal - esse materialismo (fonicidade e imagem acústica como processo mental) permite suspender o sentido de transcendência no que tange aos estudos sobre língua no Ocidente, até então.

Estabelecidas, aqui, as linhas, dobradas, para uma arqueologia do beletrismo, podemos indicar que: a) não 
pressupõe apenas conformismo e cooptação, mas, principalmente, a separação da atividade filosófica da atividade administrativo-política; b) puro trabalho formal desvinculado do estilo de vida de quem o pratica; c) negligência quanto ao papel de cidadão que, queira ou não, participou da invenção do Estado como instituição de direito público e que, como tal, deve ser submetido à sociedade civil, e não o contrário; d) no limite, e com a supressão da luta de classes, bela será a vida, e como obra de arte; e) a língua como fenômeno social só faz sentido se materializada numa enunciação coletiva e revolucionária.

Como já citamos, é durante o retinir de armas da Primeira Guerra Mundial que, conforme Benveniste (citando Nietzsche), o Curso de linguística geral, ${ }^{9}$ organizado pelos alunos de Saussure, aparecerá, revolucionariamente, como "patas de pombos". E não só porque mudará definitivamente a linguística do século $\mathrm{XX}$, proliferando os mais diferentes grupos e centros linguísticos ao redor do mundo, mas, principalmente, por acompanhar a literatura numa revolução cultural sem precedentes.

Em Literatura e revolução, Leon Trotski, ${ }^{10}$ além de combater a noção de literatura proletária - que, segundo seu ponto de vista, como também do ponto de vista de Lenin, seria inviabilizar a abolição da luta de classes - , propõe que a função da literatura fosse a de se apropriar da simbologia da cultura secular burguesa numa oficina de reinvenção do mundo junto com os trabalhadores - estes que, de fato, junto com a natureza, produzem a riqueza material existente. 
Outros Shakespeares analfabetos seriam formados não apenas por políticas literárias efetivas de um Estado proletário em transição e/ou em círculos de cultura, a exemplo do que foi proposto e praticado por Paulo Freire, no Brasil, mas no trabalho cotidiano e de resistência à exploração do trabalho onde quer que essa exploração viesse a ocorrer. Sua pergunta-chave sempre foi: de que lado, na hora do quebra-quebra revolucionário, estariam os escritores, no front ou conspirando contra a revolução? Em que pese a vigilância do partido sobre a produção literária e cultural, com a revolução bolchevique em 1917 nenhuma liberdade de expressão, nem de experimentação formal, foi cerceada pelo Estado revolucionário.

Segundo as palavras de Trotski:

A tarefa principal da intelligentsia proletária para o futuro imediato não está, entretanto, na abstração de uma nova cultura - cuja base ainda falta -, e sim no trabalho cultural mais concreto: ajudar de forma sistemática, planificada e crítica às massas atrasadas a assimilarem os elementos já existentes da cultura já existente. ${ }^{11}$

\section{Ainda, conforme as palavras de Lenin:}

É fora de discussão que, menos do que qualquer outro, o trabalho literário não é passível de nivelamento mecânico, de um domínio da maioria sobre a minoria. É fora de discussão que, nesse campo, é necessário garantir o máximo espaço à iniciativa pessoal e às inclinações individuais, o máximo espaço 
ao pensamento e à fantasia, à forma e ao conteúdo (...) Estamos longe da ideia de pregar um sistema uniforme ou uma solução do problema mediante qualquer deliberação. Não; nesse campo, não há lugar para esquematismo. ${ }^{12}$

O impacto desse olhar sobre a função social da literatura e da língua incendeia o mundo, mas dura pouco, até o advento de duas pragas contrarrevolucionárias: o nazifascismo e o stalinismo.

Em O que resta de Auschwitz, Giorgio Agamben, ${ }^{13}$ após rigorosa pesquisa arqueológica, nos revela, não sem assombro, que a maior façanha do nazismo, em seus campos de concentração, não foi apenas a de experimentar, em seus laboratórios, a destruição da língua, como instrumento de linguagem, de quase seis milhões de judeus (maioria de artistas e intelectuais), antes de levá-los às câmaras de gás.

Para Agamben, esse laboratório de destruição da língua, dos assim chamados muçulmanos, se dava não apenas de forma direta, através dos instrumentos de tortura, obrigando os judeus a falarem, mas também de forma indireta, pelos alimentos/venenos que eram forçados a ingerir visando-se ao definhamento das funções vitais dos corpos, com rebatimento direto em regiões cerebrais com a função de linguagem. E esses experimentos não se deram apenas aí, em contexto de barbárie (durante a Segunda Guerra Mundial), mas teriam sido um paradigma para um laboratório do futuro. Melhor dizendo: um laboratório com funcionamento a pleno vapor em nosso tempo presente. 
Por sua vez, o stalinismo, por meio de várias instituições culturais controladas pelo Partido Comunista, sobretudo a partir do Primeiro Congresso de Escritores Soviéticos, de 1934, instituiu não apenas o controle da experimentação formal e da expressão da imaginação criadora, por parte de escritores e artistas, mas também impôs os temas de interesse do Estado, seja nas propagandas de si mesmo como Estado proletário, seja como inimigo do Estado burguês.

A noção de realismo socialista, como degradação das condições de possibilidade para uma apreensão e crítica dialética do real, na sua relação com o imaginário e o simbólico, seria um puro reflexo da realidade. E aqueles que criticassem esse tipo de política de Estado não só teriam sua obra censurada, mas também, como ocorreu em milhões de casos, seriam aterrorizados ou mesmo assassinados, a tal ponto que o crítico italiano Vittorio Strada, segundo Wilton Oliveira, vai dizer que

o realismo socialista vai produzir no campo das artes e da literatura um estrago que não se compara sequer ao que produziu o nacional-socialismo na Alemanha nazista. Usando como argumento a necessidade de educar as massas em direção a uma sociedade de iguais, formou-se uma sociedade cujos dirigentes só toleravam o escritor ou o intelectual como elemento integrado e subordinado ao "espírito do partido". ${ }^{14}$

Com a Guerra Fria entre os Estados Unidos e a União Soviética, do fim da Segunda Guerra Mundial ao início dos 
anos de 1990, vimos, através da produção artística e literária, bem como através da produção na área das ciências humanas, o retorno em diferença das mais radicais modalidades de experimentação formais oriundas do início do século $\mathrm{XX}$, anteriores ao autoritarismo de Estado, e uma virada linguístico-literária em todas as ciências humanas, como condição não apenas de renovação teórica e metodológica, mas como espaço de enunciação de sujeitos, grupos, tribos, nações, desterritorializados de sua língua, cultura e território de sociabilidades e construção de si.

Assim, o(a) estudioso(a) do campo linguístico-literário, em tese, seria aquele(a) que, ao utilizar as mais diferentes ferramentas de pesquisa, ensino e extensão, perscrutaria a língua como fenômeno social e possibilidades artísticas, sua realização fonológica e escrita, bem como seus efeitos nos processos de subjetivação e práticas do significante e do sentido em quaisquer que sejam as comunidades linguístico -literárias existentes, da mesma forma que nas comunidades que já existiram, como prospecções e roteiros semióticos.

Mas ao se perguntar a um estudante em processo de preparação para sua entrada num curso de Letras: o que lhe ocorreria como horizonte de estudos e prática profissional? Para alguns, certamente, Letras seriam como estrelinhas brilhando no espaço sideral ou no fundo de sua cabeça; para outros, a oportunidade de dominar a língua e cultura gregas, latinas, ou mesmo línguas indígenas e africanas, sânscrito, mandarim, ou simplesmente o sonho, formatado, de falar inglês fluentemente como um britânico ou 
um norte-americano; e para outros, ainda, o único curso disponível e mais fácil de selar sua entrada numa faculdade privada ou numa universidade pública.

Portanto, há uma imensa distância, ao menos no Brasil, entre desejar fazer um curso de Letras e um de Medicina, Engenharia, Direito, Ciência da Computação, e mesmo qualquer outro das ciências humanas ou sociais aplicadas, tais como, respectivamente, História, Ciências Sociais, Ciências Contábeis, Administração e Comunicação. Que papel o mercado profissional jogaria nessa escolha ou emergência do desejo? E se não fosse o mercado das Letras a impor o beletrismo e as formas de cooptação, que outros mercados vislumbrar, que outras estranhas instituições inventar?

\section{REPÚBLICA DE PAPELETRAS COMO TRAIÇÃO DE CLASSE}

Vimos, até aqui, os usos do campo linguístico-literário feitos pelos diversos dispositivos de poder, de direita e de esquerda, bem como através dos mais diferentes atores sociais, desde a carta aberta do artista plástico Gustave Courbet, provocada pela Comuna de Paris.

Os usos que a extrema-direita, representada pelo nazifascismo, fez dos campos de concentração se diluíram nas imagens do holocausto e numa espécie de metafísica da barbárie, em que não há culpados nem inocentes e, 
como tal, parecem circular livremente como simulacros da vida contemporânea. Já os que a extrema-esquerda fez, crente de que estava emancipando a humanidade, e que se esbarraram na potência da língua e da literatura em seus usos libertários, culminaram num clichê de difícil solução: a ordem do discurso é uma traição de classe.

Como tem sido árduo para certo marxismo mecanicista enxergar outra noção e prática de luta para além da luta de classe e sua contraditória epistemologia! Isso se traduz pela emergência da consciência de explorado num trabalhador - em dado lugar da exploração capitalista - que se articula em coletivos de trabalhadores iluminados por uma minoria revolucionária. Estes, contudo, se organizariam em torno de uma primeira etapa, que seria uma revolução democrático-burguesa a qual cairia numa outra etapa, que seria a revolução proletária. Esta, por sua vez, faria perecer o Estado (transitório) para, finalmente, se darem a abolição da luta de classe e o advento do comunismo e da sociedade humana emancipada do jugo capitalista.

E se a emergência da consciência, numa multiplicidade de coletivos de trabalhadores, se der em 100 mil lugares diferentes no tempo e no espaço da exploração capitalista, como seria essa dinâmica etapista? Imaginando as mesmas estratégias de dominação por parte dos aparatos burgueses, forçando a mesma leitura dos clássicos da revolução na instalação de Estados proletários e forjando a mesma temporalidade nos processos diferenciais de transição dos diversos Estados proletários para uma sociedade 
comunista, ou seja, senão inviabilizando completamente o próprio materialismo histórico em seu devir e acontecimento epistemológico, como se daria a interpretação desse fenômeno, pelas minorias revolucionárias, senão supondo o mesmo conjunto de afetos para uma miríade de coletivos de trabalhadores em processos de luta diferentes?

Se a riqueza material existente deriva da natureza e da força de trabalho da classe trabalhadora - e não daqueles que detêm os modos de produção e a indústria do simulacro -, a questão revolucionária por excelência ainda continua sendo quem produziu a riqueza material existente, além da natureza e da classe trabalhadora, e para quem ela deve retornar. Ou, ainda, a única justiça social realmente emancipadora implica, necessariamente, uma apropriação, por parte dos trabalhadores, da matéria-prima, das máquinas e das fábricas. Mas isso só parece ser possível uma vez afirmadas e praticadas todas as formas de luta contra as ordens de despejo linguístico, cultural, territorial e ontológico a que foram e têm sido submetidos os povos da periferia do mundo ocidental.

Antes de uma teoria materialista da história, talvez seja ainda necessária uma teoria materialista do tempo, em que a língua e a linguagem, em cada ser humano, em cada corpo oprimido, reencenem a infância de cada adulto, afirmem a entrada na língua e seu laboratório da história em cada criança, como condição de emergência de outros sujeitos cujas historicidades coexistam umas com as outras. 
Se recorrermos a um sociólogo como Stuart Hall, vemos que, para o desenvolvimento dos trabalhos científicos do Centro de Cultura Contemporânea de Birmingham, teria sido necessária uma virada linguístico-literária no campo sociológico para que os pesquisadores avançassem em suas teorias, métodos, técnicas de pesquisa, além de condição de emergência para novos problemas epistemológicos, a exemplo dos estudos de gênero, raça, diáspora, minorias. Outras posições de reconhecimento da potência do campo linguístico-literário e suas conquistas científicas e estético-políticas podem ser ainda mapeadas na obra de um antropólogo como Claude Lévi-Strauss, de um psicanalista como Jacques Lacan, de um historiador como Carlo Ginzburg, de filósofos como Gilles Deleuze, Giorgio Agamben e Jacques Derrida.

Além do reconhecimento, foi possível às ciências humanas e mesmo à matemática multicultural, pela teoria da significação e da abertura do significante e, recentemente, pela teoria da enunciação, sobretudo nos últimos 50 anos, desmontar o positivismo matemático como único critério científico, em movimento desde o século XVI, e abrir ao pensamento contemporâneo um novo desafio: "a redefinição do transcendental em função de sua relação com a linguagem". ${ }^{15}$

Agindo contra a lógica da tripartição - um “eu”, uma "imagem do mundo", um "livro" - engendrada pelo pensamento arborescente que atravessa os sistemas de dominação, sejam eles criados e alimentados pelo Estado e seus 
governos de direita ou de esquerda, temos uma "literatura menor", de um Franz Kafka, bem como de uma rede de escritores disseminados pelo mundo, que fazem uma língua maior devir menor, minoritária, as marcas nos corpos oprimidos devir uma política da subjetivação e do cuidado de si e, das ficções pessoais, uma enunciação coletiva.

Se, com a Queda do Muro de Berlim e o esfacelamento do Bloco Soviético, em final dos anos de 1980 e início dos anos de 1990, emergiu, no dia seguinte, a chamada nova ordem mundial e seu pós-modernismo de divulgação, já sabemos, com este texto, quais eram seus aliados e, mais do que isso, por que o muro teria sido derrubado e o Bloco "Soviético" se esfacelado.

Assim, a república de papeletras se define a partir do confronto de duas gramáticas complexas: a) uma que investe no governo, isto é, no controle do povo, pelo povo e para - inviabilizar politicamente - o povo (em sua expressão e representação, aquisição de direitos e distribuição de riquezas); b) outra que, mudando o conceito de povo para o de proletário, paralisa o movimento dialético e complexo da história, suas historicidades e revolução permanente a favor da abolição da luta de classes.

O resultado desse confronto acaba por produzir essa outra imagem política para o século XXI: considerando que o verbo não se fez carne, mas apenas soldou a religião à política nas várias formas do Estado de exceção, inclusive nos ditos democráticos, é tarefa urgente tornar a palavra falada, escrita - ou, mais abrangentemente, qualquer forma 
de representação - a principal matéria-prima; visibilizar na escola communard existente sua máquina de desmontagem da relação entre palavra e coisa, quem se manifesta, sob que estrutura lógica essa matéria-prima se apresenta; e demonstrar como uma multiplicidade de associações de homens, mulheres e crianças livres fabricaram e/ou têm fabricado outras noções de direito associadas à vida libertária, para que o trono do poder esteja sempre vazio como esvaziável tem sido o significado transcendental por força do embate e da guerra de relatos que envolve todos os desterritorializados.

Assim, se o Estado é uma instituição cultural e de direito público e que, como tal, deve ser controlado pela sociedade civil organizada, até o seu completo perecimento pós-abolição do capital e da luta de classes, e se a experiência de "socialismo real", nos moldes implementados pelo stalinismo de Estado, não foi necessário nem suficiente para abolir o capital, de duas uma: ou o materialismo histórico repensa a sua noção de tempo para um alinhamento descentrado das historicidades ou a "traição de classe" será o único oxigênio para o não perecimento do marxismo e seu espólio.

\section{LETRA COMBATIVA E SOCIALISMO LIBERTÁRIO}

Numa palestra proferida na mesa-redonda "Civilização ou barbárie”, no dia 12 de novembro de 2010, em Salvador, 
no IV Seminário do CEMARX (UNEB), que teve como tema "Crise de civilização ou crise do capital: a reflexão marxista sobre os impasses do mundo atual”, encenamos estar num ambiente democrático como o da Comuna de Paris ou nos bons tempos leninistas ou, ainda, num espaço marcado por um radical marxismo multidisciplinar, começando por uma dupla provocação: qual o sentido de um sujeito, declaradamente ambivalente, pós-moderno, pós-estruturalista, crítico ferrenho do stalinismo tardio, meio marxista, meio anarquista, que opõe o super-homem à dialética, o que, me digam, esse sujeito está fazendo aqui? Ou ainda: que força terá permitido o retorno em diferença do crítico guerrilheiro expulso de Stalingrado, a cidade da revolução perdida?

Desdobrando a provocação: por que "civilização ou barbárie" e não, como na boa tradição, "socialismo ou barbárie"? Que relação há entre "crise de civilização ou crise do capital" e o tema da discussão proposta? Se se perguntar por "civilização" em detrimento do "capital" é um falso problema, por que "civilização" se opõe a "barbárie" e não a "socialismo"? Essa espécie de "lapso" conceitual não seria um sintoma de uma problemática mais profunda e que sempre escapa aos modos de ler e de interpretar de certo viés do marxismo?

Ao se instalar uma máquina de guerra conceitual no interior do próprio marxismo, propomos, ao mesmo tempo, descrever a lógica desse sintoma e tematizar a noção de civilização como perspectiva socialista. 
Concordando com Rosa Luxemburgo, socialismo ou barbárie não só implicam uma posição contra o imperialismo como fase superior do capitalismo - em que França, Inglaterra, Alemanha, Estados Unidos, desmanchando a lógica liberal da livre concorrência entre empresas, bancos e nações capitalistas, impõem a do monopólio das riquezas do mundo por um punhado de empresas e países -, mas principalmente mostram como a Rússia democrático-burguesa (pós-1905) e sua vocação colonialista também se colocam numa linha monopolista que não desaparece com a Revolução de Outubro de 1917.

No início dos anos de 1960, e com a derrocada do stalinismo mecanicista, outra noção de socialismo ou barbárie entra na cena teórica com Cornelius Castoridis. Trata-se de evocar as contribuições da Comuna de Paris, e o valor de seu poder enquanto espaço vazio, o valor de ao mesmo tempo legislar e executar, o valor da dissolução da hierarquia, ao menos financeira, entre os servidores públicos, e o valor da função do exército a serviço do povo e da revolução e não mais como segurança da classe dominante.

Esses valores, como força de combate à barbárie do socialismo mecanicista (destruição de milhões de bolcheviques revolucionários, do Exército Vermelho, e da completa alienação da classe trabalhadora), agora, no coração dos anos de 1960, deveriam se proliferar no interior das fábricas, como de todas as instituições-aparelhos ideológicos do Estado. 
No início desse milênio (precisamente em 2003), István Mészáros, em O século XXI: socialismo ou barbárie?, ${ }^{16}$ leva adiante as questões de Marx e de Rosa Luxemburgo, indicando as contradições do capital enquanto tal e os desafios históricos do movimento socialista, a ponto de inviabilizar qualquer esperança para a humanidade, se o poder destrutivo do capital e seus metabolismos, sua crise sistêmica, suas armas nucleares, seus mísseis, seus aviões e insetos não tripulados não forem destruídos, e de forma radical.

Entre essas três perspectivas de pensar socialismo ou barbárie ou seu suplemento disjuntivo, "barbárie se tivermos sorte", ${ }^{17}$ o que pensar de uma civilização a partir de um crivo radicalmente socialista? Sem insuflar literatura no cerne da discursividade marxista, seria possível essa virtualidade? Sem crítica cultural ao nazifascismo e ao mesmo tempo ao stalinismo tardio teríamos alguma chance de fazer retornar os valores da Comuna de Paris, agora como possibilidade do "salto histórico" proposto por Lenin?

Ora, grande parte do pessimismo marxista escatológico parece derivar mais dos impasses e impossibilidades de encarnação histórica de uma ideia - a luta de classes, a tomada de poder por parte da classe trabalhadora, a superação desta classe enquanto classe dividida e o advento da vida enquanto obra de arte numa sociedade comunista - do que das estratégias e práticas equivocadas de todo o sistema marxista. Ou seja, o sistema é monolítico e não pode mudar: o problema é da realidade, que está desde sempre eivada de fetichismo burguês. 
Bem pensado, há nos últimos 500 anos, na África, na América Latina e na Ásia, povos e culturas vivendo como baratas e insetos da escatologia marxista pós-barbárie ou em contexto de barbárie.

Se fizermos retroagir à Comuna de Paris, enquanto um personagem conceitual, para o período de ocupação colonizadora na África e na América Latina, podemos divisar que grande parte dos povos existentes foram não só destituídos de sua língua política diferencial, mas de seu território, de sua cultura e mesmo de suas formas de dizer-se e afirmar-se no mundo social e "civilizatório".

Eram formas de representar o mundo comunal em diversas línguas e num espaço temporal que não cabia na linha reta da história, seja ela positivista, mecanicista e etapista; eram formas de relação com a terra e com o espaço, completamente fora da lógica racionalista e da ordem jurídica, seja ela iluminista, fundada no economicismo e suas noções de acumulação pela via do trabalho; eram formas, enfim, de construção de um sistema identitário e de pertencimento, fundadas numa outra ordem coletiva, nômade, contra o Estado e suas efetuações e irracionalismos.

Quando intelectuais marxistas lamentam profundamente a perda das alianças comunistas pós-Segunda Guerra Mundial, a emergência da polarização soviética - isto é, incluindo os países inventados pelo stalinismo e seus tanques de guerra e de ocupação - e o fim do Estado de bem-estar social, pergunta-se: e as baratas-povos pós-pré-barbárie 
que povoavam e/ou povoam contemporaneamente os tristes trópicos?

Se a condição, marxista por excelência, da tomada de consciência enquanto objeto de exploração e da possibilidade de ser sujeito é factível aos povos colonizados, no momento mesmo da ocupação linguística, territorial, cultural e ontológica, em tempos mercantilistas ou imperialistas, então não se trata apenas de arrebanhá-los através de partidos e de sindicatos para, numa evolução da consciência e da organização de classe, projetar as etapas até o advento do comunismo, mas de abrir a teoria para a assimilação de outras formas de produção de conhecimento combatente, outras formas de resistência ao processo de barbárie, outras formas de multiplicação do sentido da vida social.

Assim, propomos uma reflexão sobre a noção de barbárie no interior do próprio pensamento marxista. O que teria feito o super-racionalismo burguês, que Lukács ${ }^{18}$ chama de irracionalismo, com as organizações e estruturas do sistema marxista? Ou, ainda, o que o desvio stalinista da teoria - o socialismo em um só país, a conceitualização do acontecimento antes de conhecê-lo, a destruição sistemática do experimental, a imposição do coletivo em lugar do trabalho da subjetividade - teria provocado no interior do sistema, impedindo-a de progredir, de ultrapassar as fronteiras da classe trabalhadora e ser, hoje, ensinada e difundida entre as crianças, os índios, as mulheres, os negros, os homossexuais? 
Sabemos que ninguém, nenhum grupo, tribo, nação, pode prescindir da pergunta sobre quem produz a riqueza, além da natureza e da força acumulada do trabalho, como condição de entendimento da lógica de distribuição sistemática de migalhas e misérias, mas, indo além dessa pergunta e do simples entendimento, como torná-la pedagógica, afirmá-la como uma arma de todas as tribos em suas lutas de reparação econômica, cultural e política? Com certeza, não será nem nos sindicatos nem nos partidos.

Para evitar a dizimação completa, ou essa barbárie às avessas, de um pequeno grupo de sindicalistas fingindo representar a categoria ao portarem bandeiras e palavras de ordem completamente ignoradas pela maioria, de um pequeno grupo de intelectuais portadores do espólio marxista e do segredo da interpretação última e da prática correta dos preceitos e receitas contra os males do capitalismo fetichista, bastaríamos retomar, evocar, reinventar, cartografar coletivamente os principais valores da Comuna de Paris que, combinados com uma cultura da linguagem, permitissem aos novos sujeitos esvaziar o sentido de um poder político absoluto e, ao mesmo tempo, o sentido absoluto de qualquer signo.

Um marxismo de bolso, enfim, e com apenas alguns princípios. Por que há pobres e ricos? Isso vem de uma luta de classe. Por que o pobre quase sempre acha que sua condição é uma natureza ou uma ordem divina? Isso deriva de uma imposição e naturalização de uma lógica perversa fundada no valor de troca e não no valor de uso. 
O que é valor de uso? O que é valor de troca? O primeiro, a qualidade do trabalho onde quer que ele ocorra e não apenas no interior das fábricas; o segundo, a substituição do trabalho pela ênfase em seus produtos expostos na vitrine e através da propaganda e do marketing. Como tomar consciência disso? O sentimento de insatisfação por qualquer forma de exploração econômica, política, linguística, familiar, religiosa já é um modo de acontecimento e de leitura do corpo. Como organizar esse sentimento numa forma política? Formar grupelhos não esquecendo que há outros em situação idêntica, e desde sempre. Seria possível, então, a emancipação da humanidade através dessa multiplicidade de grupelhos? Não sabemos ao certo, mas só faz sentido lutar sabendo por que se luta. E, em cada contexto, um ato simbólico como cultura política, o crivo de uma luta de classes para se devassar a lógica da representação fetichista e uma consciência da ideologia da forma e seus modos fabricar, falsificar e representar os diversos níveis da realidade.

Assim, poderíamos não só imaginar e inventar concretamente uma sociedade civil marxista, mas, mais importante do que isso: situar, nas diferentes sociedades e em todos os tempos, a gênese de seus precursores. Uma nova metafísica? Não. Um esvaziamento de um sistema de verdades, o marxismo mecanicista, inflexível, mumificado, por um signo estratégico e combativo, acessível a todo e qualquer trabalhador/a, em sua luta cotidiana com os patrões, mas igualmente contra sua ordem simbólica e 
processos de subjetivação reacionários, sejam de direita, sejam de esquerda.

Um marxismo ensinado às crianças seria também uma forma de evitar o seu perecimento e barbárie. Evidentemente que não estamos propondo brinquedinhos barbados, a exemplo de um Marx Barbie, ou fotos de Stalin, Mao Tse-tung, Che Guevara povoando os quartos dos bebês, mas de reinventar a pergunta marxista por excelência nas mais distintas situações e contextos pedagógicos.

Se entendermos por infraestrutura a série econômica, estatal e o cotidiano das pessoas e por superestrutura a série ciência, moral e artes/cultura, então, de um ponto de vista marxista contemporâneo, podemos inferir que entre pessoas, sujeitos, tribos, que constituem a infraestrutura, podem existir ao menos um, com sua acumulação cultural, capaz de deslocar a ordem do fetichismo burguês (que atravessa ciência moral e arte) e modificar, desorganizar, revolucionar a ordem infraestrutural. Logo, a infraestrutura pode ser também determinada pela superestrutura.

E não se trata apenas de cultura sindical e partidária que, nesse caso, me parecem as mais incompetentes para fazer isso, mas da distribuição de uma multiplicidade de comunas através da ordem cultural. Um contraexemplo: a grande façanha do fetichismo burguês e seu super-racionalismo é fazer com que sua lógica se reproduza através das diferentes e atuantes formas de representação (artística, científica, religiosa) da realidade e confundir a realidade 
ela mesma com as formas de sua representação, tornando indiferenciável ficção e realidade.

O que aconteceria, então, se o marxismo clássico passasse a se interessar também pela questão cultural como a forma marxista e revolucionária, por excelência? No mínimo, teríamos que repensar todo o estrago que o stalinismo fez reduzindo a cultura à propaganda partidária $\mathrm{e}$ retomar, em outros termos, e com as contribuições teóricas e práticas pós-Maio de 68, o legado de Lenin e de Trotski, em termos culturais, a saber: em vez do investimento numa cultura proletária - que seria inviabilizar a revolução -, investir no saqueamento e apropriação da matéria-prima cultural burguesa, de suas máquinas de produção de signo, enfim, de sua fábrica, e oferecê-las aos trabalhadores/as, às crianças, aos negros, às mulheres, trucidados, desde sempre, pela ordem fetichista.

Nesse sentido, política passa a ser a forma revolucionária por excelência de se fazer cultura. Semelhante ao que Isaac Bábel, escritor soviético e membro da Cavalaria Vermelha em seus tempos áureos, fez ao denunciar a deformação do espírito revolucionário quando os burocratas começam a emergir com estatuto do partido debaixo do braço e desqualificando qualquer perspectiva de vida política que não fosse a mecanicista, mas também ao se apropriar daquilo que havia de mais rico e afortunado da forma cultural burguesa.

Um exemplo agora bem recente e próximo de nós é o filme de Deivison Fiuza, Carregadoras de sonho, ${ }^{19}$ de 2010, 
que trata da vida de professoras primárias da Bahia e de Sergipe. O Sindicato dos Professores de Sergipe (SINTESE) cria as condições para que um de seus artistas estude e se aproprie das várias técnicas do documentário, do cinema verdade e de outras cinematografias alternativas, e a baixo custo, e produza um objeto cultural (o filme) capaz não apenas de descrever a vida e o cotidiano de professoras como um ato simbólico e de intervenção na difícil realidade escolar da educação básica em suas primeiras séries, mas ainda de oferecer os signos para se pensar a luta de classes, além de colocar-se como ativista contra uma ideologia da forma ${ }^{20}$ de representar vida de professores.

Por fim, uma última pergunta: fazer política socialista (organizar-se em sindicatos, lutar contra os patrões, assumir o parlamento burguês para fortalecer a luta operária, criar um Estado proletário e suprimi-lo para que a emancipação de classe ocorra) é também uma forma cultural e histórica que teve seu início, seu desenvolvimento, sua acumulação, seus desvios, suas deformações, seus retrocessos, sua paralisia, sua mumificação, e se é assim como se configura o seu discurso? Em que consiste sua ideologia formal? Existe algo pronto e acabado para além dos homens e da história, ou essa forma cultural revolucionária só existe porque existem sujeitos solidários e empenhados na conquista da vida como poética da existência?

Queremos dizer, enfim, que o marxismo como um arquivo e espólio de partidos e sindicatos pode desaparecer que não fará falta à humanidade. Já como pergunta sobre a 
forma do fetichismo e como organização e prática cultural contra uma ideologia da forma - seja ela burguesa, seja ela referente à atrofia do próprio marxismo e seus enlaces suspeitos -, isso sim, essa perda é irreparável. Seria a forma da barbárie que nós, os insetos e baratas pós-apocalípticos, não teríamos outra condição senão perecer. A luta desarmada continua.

\section{CONTRADISPOSITIVOS: EQUIPAMENTOS DE CRÍTICA CULTURAL COMO POTÊNCIA LITERÁRIA}

Um falso problema, e bem atual, ainda envolve o campo linguístico-literário, a saber: a naturalização de um discurso sobre a ausência de condições para que comunidades de leitores explorem as forças da escritura, em termos de mimesis, mathesis e semiosis, ${ }^{21}$ sem levar em conta os dispositivos estatais e o controle das formas intelectuais e afetivas de produção nesse campo.

Para tematizar esse falso problema, iremos reunir, num primeiro momento, um conjunto de situações políticas e institucionais que envolvem o campo linguístico-literário ao sistema científico no Brasil, e enquanto política de desenvolvimento institucional em uma universidade de pequeno porte - como a Universidade do Estado da Bahia (UNEB) -, fazendo emergir dispositivos de poder e sua malha microfísica e micropolítica. Num segundo momento, indicaremos as limitações de uma leitura literária 
desinteressada e fruitiva, para, num terceiro momento, e a partir dos equipamentos de crítica cultural como potência literária, refazer o problema e propor alguns critérios para se dramatizarem as ordens de despejo linguístico, cultural, territorial e ontológico de povos colonizados. Vislumbramos, com isso, construir um lugar de solidariedade científica entre pesquisadores e comunidades culturais e educacionais excluídas desse sistema científico.

A questão correta, antiga por sinal, é: seria a literatura ou o campo linguístico-literário o lugar por excelência de uma tecnologia do signo capaz, ao mesmo tempo, de dramatizar a maquinaria de poder estatal e oferecer ferramentas para a anulação de dispositivos situados nas relações palavra-coisa, quem se manifesta nos atos de nomeação e sob que estrutura lógica se organiza este ou aquele pensamento/proposição ${ }^{22} \mathrm{Ou}$, ainda, como através da literatura, transformada num operador simbólico, mobilizar vários domínios do conhecimento, e esvaziar a lei, a força reacionária de lei, que subjaz ao Estado de exceção em seu conluio com a metafísica e com o capital?

\section{MO(VI)MENTO 1: PRESCRIÇÃO E EXECUÇÃO}

Retomemos uma cena da mesa-redonda "Ensino de literatura em perspectiva comparada" proposta no XIII Congresso Internacional da Associação Brasileira de Literatura Comparada (ABRALIC), em Campina Grande, Paraíba, em julho de 2013. Foram lidas as comunicações 
"Enseignement de la littérature: expérience esthétique et formation du lecteur", por Annie Rouxel, da Université Bordeaux, e "A 'formação do leitor' na escola pública brasileira: um jargão ou um ideal?”, pela pesquisadora da Universidade de São Paulo (USP) Neide Luzia de Resende, da área de educação. Esta, que também esteve na base de criação e coordenação dos Parâmetros Nacionais Curriculares (PCN), pontua, com todas as letras, que o maior problema relacionado ao quadro desolador que envolve a formação do leitor no Brasil se deve à péssima formação, também, dos profissionais de Letras, por estes ainda se preocuparem apenas com a "análise" de textos literários em sala de aula.

Que o fechamento puro e simples na leitura cerrada do texto literário (em contexto de formação de leitores) seja problemático, não há dúvida; mas essa questão da formação para a "análise" de textos literários, de um ponto de vista crítico-cultural, já foi debatida, esconjurada em muitos programas de pós-graduação da área de letras e linguística, além de ser posta de lado na graduação em muitos cursos pelo Brasil, a partir da crítica às belas-letras e da inserção do multiculturalismo como emergência teórica, metodológica e signo radical do declínio da arte. ${ }^{23}$

Assim, o profissional de Letras referido ${ }^{24}$ implica, talvez, apenas o profissional formado pela USP e sua nucleação ou área de influência, cujo contraponto seria uma série de experiências inovadoras desenvolvidas em espaços epistemológicos liberados daquela "colonização" uspiana. Assim, aquela interpelação pública de uma educadora 
exigindo outra formação para os profissionais de Letras, em pleno congresso da área de literatura comparada, revela não apenas um desconhecimento de inovações curriculares relevantes e práticas de leitura inovadoras, mas, principalmente, uma espécie de correção aos desvios do que fora prescrito pelos $\mathrm{PCN}$, bem como um ajuste da inteligência e da sensibilidade ao que fora normatizado.

No XXVIII Encontro Nacional da Anpoll, em 2013, há outras cenas que merecem ser, também, aqui pontuadas. A primeira seria pontuada a partir do contexto dos novos desafios para a área de letras e linguística, ${ }^{25}$ a saber: a educação básica, a interdisciplinaridade e a internacionalização. Sobre a educação básica, como desafio, os pesquisadores - credenciados em mais de 140 programas da área -, além de atuarem nos níveis de graduação, com ensino, pesquisa e extensão, e em dezenas de linhas de pesquisa, formando professores, mestres e doutores, em condições de perguntar e praticar questões sobre o que é educar de um ponto de vista linguístico-literário, mesmo assim esses pesquisadores filiados aos programas da área são ainda responsabilizados pelo Ministério da Educação, através da CAPES, quanto ao "desafio da educação básica”. Ora, se "no PNPG 2011-2020 a área de letras e linguística não é contemplada, apenas pega carona na educação básica", então temos aqui uma contradição incontornável: embora detentora de um saber sobre a linguagem e suas possibilidades expressivas, o campo linguístico-literário, no sistema científico brasileiro, não 
dispõe de um lugar estratégico para sua prática científica ou, por ser a área obrigada "a pegar carona na educação básica”, dever ser permanentemente destituída da possibilidade de ser esse lugar estratégico.

Em outra conferência do referido encontro, "Formação em letras e linguística hoje: desafios e conquistas", ${ }^{26}$ demonstraram-se as conquistas linguísticas no Brasil nas últimas décadas, mas saltou aos olhos de todos, também, a necessidade de exclusão da Linguística Aplicada, em todas suas vertentes, bem como a necessidade do conformismo, sem questionar, ainda, o labirinto em que se coloca seu comitê de assessoramento: a área de letras e linguística disputa território com outras 17 áreas, coordenadas pelo Diretor de Engenharias, Ciências Exatas e Humanas e Sociais (DEHS).

Em posição contrária à dos conferencistas anteriormente mencionados, o coletivo de coordenadores de programas e de coordenadores de grupos de trabalhos procurou situar o lugar institucional que cada coordenador deveria ocupar como representante da sociedade civil organizada, bem como estabelecer outra perspectiva para uma associação científica, que, em princípio, deveria estar comprometida com o debate, organização e criação de um movimento a favor de uma política da linguagem humana e de seus direitos linguísticos, culturais, territoriais e identitários. Em segundo lugar, rascunhamos um documento, como coordenadores de programas e 
de grupos de trabalho, cujas linhas gerais apontaram para: elevação do status do campo linguístico-literário no sistema científico brasileiro a partir da visibilização das contribuições do campo às grandes políticas públicas do país quanto a ensino, pesquisa e extensão de língua e literatura, em todos os níveis da educação, passando pela política cultural e suas noções de livro, literatura, biblioteca e leitura, até as políticas de tradução prospectiva, vislumbrando o protagonismo internacional do Brasil, como potência econômica mundial, sobretudo em parceria com os países dos BRICS.

Assim, se por um lado o Estado prescreve - e sabemos que sempre articulado com uma lei metafísica e como aliado do capital -, a partir de documentos de área, regimentos gerais das universidades e dos programas aprovados, por outro o movimento social, na figura de seus representantes, reescreve: aquém da "análise" de textos literários em sala de aula e para além do prescrito pelos PCN, os alunos são estimulados a ficcionalizar a barbárie cultural que vivenciam e a se colocar como autores de outros signos e sentidos libertários.

Não se trata, portanto, de desqualificar, ainda mais, os cursos de Letras, seus profissionais e alunos, exigindo deles a assimilação do Estado de exceção em seu limite - definharem-se como portadores da capacidade de linguagem e de produção de sentido como condição de humanidade e vida inteligente e sensível -, mas de convocá-los, em conferências nacionais, estaduais e municipais permanentes, 
para se pensarem, definirem e praticarem outras noções de direitos linguísticos e literários.

Se as noções de direitos linguísticos e literários são hoje decisivas, na definição de qualquer política pública e/ou política de conhecimento, por que a UNEB exclui do seu Plano de Desenvolvimento Institucional (PDI) 2009-2012 o campo linguístico-literário, ao confundi-lo com pedagogia ou educação? E não se trata de um alinhamento por ser essa universidade vocacionada para os cursos de licenciatura ou com ênfase no ensino. Pois, se assim fosse, outros cursos de licenciatura, tais como os de História, Química, Biologia, entre outros, deveriam ser subsumidos pelo conceito de educação ou pedagogia, mas isso não ocorre, e esses cursos ou campos de conhecimento são mantidos como estratégicos e considerados com fortes demandas dos territórios de identidade ou regiões administrativas (RGDs). Acrescente-se a essa indiferença institucional o fechamento, nos últimos três anos, de dois dos dezenove cursos de Letras (em Xique-Xique e Itaberaba), sendo substituídos por Engenharia de Pesca e Agronomia.

Não estaria faltando ao profissional das letras certa cultura política que o estimulasse a pensar o lugar do campo no sistema científico e nas políticas públicas? Ou, ainda, como o conjunto de professores e de estudantes no trabalho linguístico-literário, em todos os seus níveis de formação, deveria situar-se como despejados linguísticos, culturais, territoriais e ontológicos? Não seria a sala de aula, o material didático, os planos de curso e de aula, em sentido 
macro e micro, uma série de dispositivos que precisariam ser repensados, questionados, anulados e reposicionados, a favor de uma cultura linguístico-literária cidadã?

Dado que o despejado linguístico é aquele que teve sua língua destruída ao memorizar e reproduzir nela valores subjetivos, históricos, culturais, cosmológicos, de outras línguas de dominação, sem se dar conta de uma alienação simbólica, na sua trama entre um real e imaginário impostos, o trabalho político de uma universidade de pequeno porte (como a UNEB) seria organizar outra política do conhecimento. Isso poderia ser feito através do campo linguístico-literário, na interface com outros domínios que começasse por uma tecnologia social do signo, cuja pedagogia libertária assumisse com desenvoltura o fragmento resultante do rompimento da relação entre palavra e coisa, reposicionasse o circuito da manifestação política, tendo como ator principal esse ser desterritorializado e sua lógica, paradoxal, de produção de sentidos.

MO(VI)MENTO 2: ESCRITURA E SALVAÇÃO

As forças da escritura - a mimesis, com sua potência de representar o real, mesmo quando o nega fazê-lo ou o faz através de uma estética do fragmentário; a mathesis, com sua potência de articular qualquer domínio do saber no monumento literário; a semiosis, por fazer do signo literário um espaço aberto à potência criativa dos leitores, 
independentemente de seu nível de formação e capacidade de interpretação -, pelo que dissemos no "Mo(vi)mento 1 ", tais forças só fazem sentido se articuladas a favor da desmontagem permanente do Estado de exceção: sua forma de nomeação, institucionalização e circulação dos efeitos de sentido, seus déspotas, sua lógica e/ou seus dispositivos de funcionamento. Assim, essas forças, por elas mesmas, como atividade desinteressada, como pura fruição, seriam uma forma de reprodução dos valores do Estado de exceção.

Se, agora, posicionando a máquina literária como uma ferramenta voltada à anulação e desmontagem de dispositivos de poder, perguntássemos pelo lugar das políticas públicas, pelo papel do Estado, pelas agências de fomento à pesquisa, pela escola como um lugar do exercício permanente do ato de conhecer, teríamos não só uma reabertura do imaginário e a produção de outros cenários como crivos do real, mas a distribuição de uma riqueza incomensurável: uma tecnologia do signo acessível em toda situação de leitura, literária ou não.

O prescrito se apresenta sempre com um sentido fixo, através da sombra de uma autoridade e como imposição naturalizada de uma lógica, ainda que sejam as três forças, anuladas, da escritura. Por isso, para a máquina literária funcionar, devemos, a exemplo de Franz Kafka, desmontá-la já a partir da metáfora, como um dispositivo reacionário, e criar condições, no ato pedagógico de leitura, 
para, ao mesmo tempo, situar o déspota em sua rede de poder e instaurar outra série semiótica ou ressemiótica, como condição de uma práxis política transvaloradora.

O que é mais radical em tal práxis é que, muitas vezes, devemos, como despejados que somos, partir de uma marca no corpo de si mesmo, de uma pessoa, grupo, tribo, nação, como ponto de partida de uma cultura política revolucionária. Assim, aquele verbo que se fez carne deve passar por um crivo arqueológico (quem é que é o verbo, sob que condições de significação, quem o pronunciou como ato de nomeação, sob que estruturas lógicas ou cultura do ato de conhecer) e tornar-se palavra arbitrária devassada e marcada de historicidades.

Numa situação pedagógica qualquer, em que esteja em jogo um texto literário, uma cena gramatical, basta fazer o poder aparecer como o ponto de uma série para que toda a rede do poder possa ser visibilizada, mapeada, dramatizada. Assim, o que é ativo, o que interessa, como posição política e crítico-cultural, não é a leitura cerrada de um texto literário enquanto demonstração de uma riqueza simbólica em si mesma, mas como esse ato de conhecer e simbolizar um despejado linguístico, cultural, territorial e ontológico assume o poder de autorrepresentar, de jogar com suas ficções pessoais, de retomar sua potência de simbolizar e ressignificar o mundo sob sua mira estético-política.

Qual o mais radical sentido de riqueza: a do texto literário em si mesmo ou a de um sujeito qualquer - sobretudo 
os despejados - se dando conta de sua potência de simbolização? Qual riqueza um país A ou B poderia desejar e efetivamente implementar para o seu povo: a de cada um poder dispor de riqueza material fetichista ou a de cada um com a potência de poder dispor simbolicamente do mundo para afirmar a estética de sua existência, na relação com os outros, sem aquele fetichismo que forma e conforma a cultura burguesa?

Se a condição de poder dispor de uma tecnologia dos signos é efetivamente a maior riqueza que um país pode e deve oferecer ao seu povo, qual o sentido de um sistema científico, uma associação para política de pós-graduação, uma universidade com uma dezena de cursos de Letras, um plano de aula ou de curso voltado ao exercício da literariedade pela literariedade: cada um desses dispositivos, a sua maneira e com sua função, inviabilizarem tanto os direitos linguísticos e literários quanto a afirmação e desenvolvimento de um mercado diferencial para as trocas simbólicas?

\section{MO(VI)MENTO 3: ENTRE A ESCRITURA E A PROSCRIÇÃO}

Um dos equipamentos, montado com recursos públicos de editais do Programa de Pós-Graduação em Crítica Cultural, é a Fábrica de Letras. Em seus cadernos produzidos pelos Círculos de Crítica da Cultura, além de versões, com até 60 páginas, de dissertações e teses desenvolvidas pelo programa - cujos temas, em linhas gerais, tratam 
daquelas ordens de despejo já mencionadas -, vislumbramos, ainda, a publicação de entrevistas, textos, poemas, diários biográficos, autobiográficos de professores, estudantes, escritores, artistas, gestores das escolas públicas e equipamentos de cultura com os(as) quais mantemos relação de parceria e produção compartilhada.

Essa produção compartilhada potencializa-se a partir de outros equipamentos: o cinema digital, como laboratório, a estação do livro digital, o centro de restauração de impressos raros e o laboratório da personalidade cultural cenográfica. Através do cinema digital e sua política de formação e sedução de plateias, exibimos filmes sobre o universo linguístico-literário na escola e sua relação com a vida de professores, alunos, escritores, artistas e seus circuitos institucionais, além de, num segundo momento, a exibição regular, sempre seguida de debates, de uma cinematografia fora do eixo hollywoodiano, com o objetivo de se abrir outra rota para o imaginário político, sobretudo aquela que poderia ser desencadeada pela produção de países como China, Rússia, Índia e África do Sul.

Com a Estação do Livro Digital e o Centro de Restauração de Impressos Raros, damos tratamento a um tipo de material (diários, jornais antigos, cartas de alforria, revistas, livros antigos, arquivos de secretarias de educação e de cultura sobre produções literárias e de língua portuguesa, entre outros), resultado de uma espécie de arqueologia das ruínas literárias e culturais locais, regionais, nacionais e mesmo internacionais, ao envolvermos parcerias com 
universidades e centros de pesquisa, ao menos com os países de língua portuguesa.

O Laboratório da Personalidade Cultural Cenográfica é uma espécie de museu, a exemplo do Acervo de Escritores Mineiros da Universidade Federal de Minas Gerais (UFMG), em que, além da guarda e tratamento dos acervos linguístico-literários e culturais doados ao programa e à UNEB, parte das obras adquiridas - bem como painéis sobre recorte biobibliográficos de personalidades - é disposta, esteticamente, em galerias para acesso de estudantes, professores, artistas e demais membros da comunidade. Temos, ainda - e por força do Programa de Cooperação Acadêmica (Procad-UNEB) do Programa de Pós-Graduação em Crítica Cultural (Pós-Crítica) com o Programa de Pós-Graduação em Estudos Literários (Pós-Lit) da UFMG -, o projeto Arquivo Literário e Cultural Itinerante, com a exposição e debate de cenas da vida literária e cultural com as comunidades com pouco acesso à universidade e ao meio acadêmico.

Como se pode notar, são atividades possíveis de um programa de pós-graduação stricto sensu, envolvendo seus pesquisadores docentes, discentes, orientandos em iniciação científica e em trabalhos de conclusão de cursos, egressos vinculados à rede de escolas e equipamentos de cultura, que partem de um olhar político sobre o principal drama do sistema científico brasileiro expresso no Plano Nacional de Pós-Graduação (PNPG 2011-2020), a saber: a produção científica, sobretudo a da área de humanidades (já que o campo linguístico-literário sequer aparece 
nesse plano), não está sendo transferida para aqueles que se situam na ponta ou na base do sistema. Mas, como já temos também os antídotos contra essa "transferência", estabelecida pelo sistema como único critério ou critério que apenas separa aqueles que sabem daqueles considerados como destituídos da potência de saber, ou, como diria Paulo Freire, é preciso combater permanentemente a lógica dessa educação bancária, sinônimo dessa "transferência”, assim o gesto político e público se amplia e radicaliza: nem forças escriturais anuladas, nem execução pura e simples do que está prescrito, mas a criação de forças políticas e coletivas que anulem os dispositivos reativos do saber e do poder.

Em nossos tempos, e com a tecnologia dos signos à disposição de qualquer cidadão, não só podemos testemunhar a favor do povo pobre e subalterno, mas fazê-la circular, de mão em mão, em arquivos de bolso, criando, assim, outras condições para que esses subalternos possam emergir como novos sujeitos históricos e portadores de outras perspectivas estético-políticas.

Há uma terrível armadilha em considerar as forças da literatura por elas mesmas ou supondo uma autoridade da interpretação que, a partir de uma leitura cerrada de um dado texto literário, oferecesse a professores e estudantes de literatura as ferramentas para uma crítica do sistema de modo geral. Antes, seria necessário localizar no texto literário uma dobra do Estado de exceção e suas formas de imposição e/ou esvaziamento do direito - nesse caso, 
direito linguístico e literário - e procurar anular seus dispositivos. Não se trata, porém, de uma atuação fora do sistema, mas a partir de suas próprias ferramentas.

Procuramos demonstrar, também, que o campo linguístico-literário, apesar do movimento de anulação de sua potência estimulado por várias instituições (inclusive linguístico-literárias), pode se tornar um campo de ciência e ação direta, sem precedentes, e radicalmente a favor de novas lutas libertárias envolvendo comunidades excluídas, sobretudo de professores, alunos e artistas da palavra.

Talvez não seja mais o tempo nem mo(vi)mento de incendiar as instituições, mas de localizar, no âmbito de seu funcionamento, os dispositivos de poder reacionário e anulá-los, sobretudo fazendo-os funcionar de uma outra forma, com funções outras, especialmente marcadas por profunda solidariedade com aqueles que desde sempre estiveram destituídos de sua potência de simbolizar sua própria existência. Aqui, como um critério radical para a distribuição da riqueza.

Não há como falar, escrever e praticar literatura periférica sem nos posicionar como um subalterno em luta permanente para fazer de nossas marcas, e feridas expostas, 0 lugar de uma política radical. Se, conforme Sérgio Vaz, ${ }^{27}$ um de seus eminentes ativistas, essa é uma literatura que nasce "das ruas violentas, da saúde precária, do ensino de má qualidade, do racismo, do preconceito de classe, do desemprego, das mazelas sociais, e que denuncia o que 
se sofre na pele / das letras descalças, mas de pés firmes e calejados que não descansam nunca / da poesia que sangra na página e umedece de lágrimas / de uma escrita órfã de pai e mãe", então não se trata, apenas, de produzir representações literárias sobre essa realidade, nem mesmo de mapear suas (auto)representações no seio mesmo das comunidades envolvidas nessa produção periférica, mas, além disso, e num gesto científico com forte solidariedade de classe, favorecer a criação de certas condições para que tal produção de (auto)representações literárias possa estar implicada a uma rede de instituições que, em vez de ser o lugar de prescrições do Estado, seja um dispositivo de empoderamento desses coletivos de artistas da palavra.

Tomando essa articulação (formas de representar combinadas com uma virada possível na gestão literária e cultural das instituições) como um princípio epistemológico, procuramos aqui tornar visível não apenas a contradição apontada pelo sistema científico brasileiro, cujo Plano Nacional (PNPG 2011-2020) ainda tem como meta a "transmissão dos resultados de pesquisa" em vez de apoiar e qualificar as inúmeras experiências voltadas à pesquisa e produção com as comunidades.

Nessa linha de trabalho científico, situamos o campo linguístico-literário como um lugar profícuo em que tanto é possível haver uma mudança da matriz curricular articulada à institucionalização da malha cultural no nosso país, quanto estimular o fomento de uma série de equipamentos 
(laboratórios de restauração de impressos raros, empresa júnior de Letras, ilhas de edição gráfica e audiovisual, pontos de leitura, bibliotecas comunitárias, entre outros) para que a literatura e a produção artística periférica, e em todos os municípios do Brasil, não sejam meros produtos aleatórios e sazonais voluntários, mas uma radical ocupação do Estado como instituição de direito público. ${ }^{28}$

Com essa articulação - em curso em muitos programas de pós-graduação stricto sensu no Brasil, sobretudo no campo linguístico-literário -, além da mediação, debate, construção e acompanhamento dos planos decenais de cultura em cada município e seu aporte de $1 \%$ do orçamento local, $1,5 \%$ do estadual e $2 \%$ do federal, é possível, também, visibilizar as dobras do Estado a partir de uma politização dos direitos linguísticos e literários.

Isso é urgente, pois não é mais tolerável que dezenas de editais destinados ao apoio do segmento literário (oficinas de criação, feiras de literatura, mobilidade de escritores, ilhas de edição gráfica) passem ao largo dos cursos de Letras e tenham como proponentes designers, psicopedagogos, fotógrafos, videomakers, simplesmente porque, em grande medida, o campo ainda continua preso ao objeto ensino de língua e leitura do texto literário.

O desafio das letras de periferia e da periferia das letras é duplo: ir além da representação da pobreza e criar os modos de sua produção, gestão e superação, combinando, nessa complexa atividade, o esvaziamento do significado 
transcendental com uma tecnologia dos signos que confronte o Estado e seu despotismo. Assim, ler um poema é também um exercício para esvaziar a (força de) lei que se proponha e se pratica como anulação dos direitos. A recusa a esse desafio é condenarmo-nos a essa condição periférica, mesmo, no âmbito acadêmico, tendo todas as ferramentas para a sua superação.

Um passo decisivo para a superação desse desafio é sem dúvida retomar a descoberta do signo e abertura de seu significante, como acontecimento cultural no campo linguístico-literário, mapear seus impactos na virada linguístico-literária nas ciências humanas, bem como, do ponto de vista linguístico-literário, acolher problemas e questões formulados pelas ciências humanas, depois de suas viradas epistemológicas, como condição tanto para um trabalho científico multidisciplinar e de fronteiras, quanto para uma atividade estético-política vinculada à pesquisa e trabalho autobiográfico ou bioficcional, assumindo, nesse gesto ou compromisso epistemológico, a estranheza e a precariedade incontornáveis de nossas instituições linguístico-literárias. 


\section{ATIVISMOS AUTOBIOGRÁFICOS}

Quando ainda criança, em zona rural do município de Itapetinga, na Bahia, ouvia minha mãe, meus tios, entre outros, dizerem que a mãe da minha avó havia sido "pegada no mato" como um bicho. Era uma índia. E provavelmente não é exagero dizer que, sobretudo em regiões mais distantes de centros urbanos, por todo o Brasil, crianças dos anos de 1960 e 1970 tenham ouvido frases semelhantes às que ouvi sobre nossos antepassados.

Mesmo habitando a zona rural, vivendo e compartilhando a vida num pequeno mundo do interior, na roça, distante da "civilização", seria nítida, cristalina, uma linha divisória entre nós e eles (nossos antepassados) se não houvesse uma naturalização da barbárie e sua problemática. Hoje, interpelando criticamente esse despotismo praticado pelos colonizadores, não há dúvida de que essa linha divisória foi colocada pela ocupação europeia do Novo Mundo. Aquela "gente", a ser salva, devia ser encarada, não apenas como bárbaros carentes de "pastores do ser", mas para justificar essa condição de pré-humanidade, seria necessário compará-los a animais como a onça, a cobra e o jabuti, além de destituí-los da linguagem que posicionaria os índios como gênero humano. 
O papel decisivo nessa demarcação parece ter sido o trabalho colonial tendo por dispositivo a língua, tanto a portuguesa quanto as indígenas. Façamos este exercício filosófico: se a língua de qualquer povo, independentemente de seu estágio civilizatório, é a condição, na infância, para que o humano se exercite, se defina e se afirme como tal, o que teria acontecido se alguma espécie de barbárie tivesse inviabilizado esse exercício? Não seria a memorização e a repetição de valores ocidentais e cristãos, através do teatro e da catequese, na própria língua do índio, uma forma de despejá-los de sua língua, ou de suas línguas, na medida em que separava a palavra (indígena) das coisas (indígenas) para impor outras coisas (as do ocidental cristão)? E se a coisa em pauta, na pedagogia da memorização e da repetição (em língua indígena), fosse o próprio sentido do ser (humano) destituído de seu universo de referência ou tendo que assumir um outro universo absolutamente estranho ao de sua comunidade ou nação?

Assim, crianças indígenas, no interior das tribos, e sob o impacto dessa pedagogia da memorização imposta pelo colonizador, não só teriam perdido a sua potência de brincar com a nomeação e renomeação do mundo a sua volta, conforme seus valores, suas experiências e práticas estético-políticas e existenciais, mas teriam sido forçadas, duplamente, a exercitarem a sua língua ao mesmo tempo como um dispositivo que as igualava aos animais ${ }^{1}$ (e não como um exercício do humano) e como um aparelho de captura que as destituía de sua historicidade, condenando-as a repetir a 
história do colonizador. Isso na melhor das hipóteses, pois o pior já sabemos: dizimação e genocídio.

Essa prática teológica de uso das línguas ocidentais ou não ocidentais por parte dos colonizadores europeus, acoplada a uma geometrização do mundo conforme a lógica ocidental emergente no século XVI, vai estabelecer, daí em diante, os parâmetros para as várias formas de divisão e cercados. De um lado, e do ponto de vista histórico, os bárbaros e, de outro, os civilizados, os portadores da "boanova"; de um lado, e do ponto de vista filosófico (século XVIII), os irracionais ou os destituídos da faculdade de pensar e, de outro, os racionais e os detentores das formas do conhecimento e da verdade; de outro lado, e do ponto de vista estético (século XIX), os que já nascem dentro de uma língua ou sistema de representação, sem atributos para distanciarem-se deles e se afirmarem como sujeito da história, permanecendo como pedras, pássaros e animais e, de outro, os demiurgos, os senhores da palavra e dos processos de criação.

Se essa frase referida à índia "pegada no mato", tão naturalizada, ou aparentemente sem importância, se tornasse um dispositivo para se questionar esses cercados, por onde, numa lógica infantil, começaríamos uma desmontagem? Talvez pelo deslocamento de um dos elementos de designação: "mato". O que é o mato? Se se refere à floresta, e se o índio, como um ser humano, é o senhor que coloniza a floresta, por que "mato", com sentido de floresta, seria um atributo negativo? Ou, ainda, se o índio (nesse caso a 
índia) é o senhor da floresta, por que seria uma presa fácil do homem branco civilizado? Será que o homem branco, ou europeu, além da dizimação ao longo de quatro séculos, no final do século XIX, já teria instalado um sistema de vigilância e captura no interior das florestas brasileiras? Por que ainda falta ou, ao menos, por que faltou às crianças dos anos de 1960 um centro de documentação nas roças e fazendas brasileiras que tratem da destruição dos povos e culturas indígenas? Imaginem a curiosidade das crianças ao olharem os mapas da caça ao índio, o conjunto das estratégias do colonizador, seus aparelhos de captura, tortura, destruição e esconderijo dos corpos?

Uma tal pedagogia cultural e libertária, própria de um Estado-nação que respeitasse o seu povo, não iria omitir ou falsificar a noção de "mistura das três raças" como condição de democracia e exemplo para o futuro, simplesmente porque, se houve mistura (e com certeza houve), qual seria o lugar de cada raça - o índio, o negro, o branco - nessa mistura, em termos de produção discursiva, instalação de instituições, apropriação dos modos de produção de riquezas e estabelecimento das condições de subjetivação?

\section{TECNOLOGIAS DO SIGNO E DEVIR REVOLUCIONÁRIO NAS PESSOAS}

Não é a palavra mágica que sustenta o ser humano em sua dimensão plástica e cósmica, mas a capacidade 
de indivíduos, tribos, comunidades de esvaziá-la de sua fortuna metafísica e transcendental ${ }^{2}$ e submetê-la a uma permanente oficina, em que cada contexto de luta implica agenciamentos diferenciais, práticas discursivas sempre abertas a um devir libertário e socialista.

As oficinas descritas a seguir, antes de partilhar dessa vontade de expressão cósmica e transcendental que tem recoberto a humanidade de misérias e produzido os farrapos humanos, convidam o leitor a reinventar a sua condição de existência a partir do materialismo cultural, ${ }^{3}$ perspectiva na qual a maior obra de arte seria a vida pós-abolição da luta de classes e a distribuição equitativa das riquezas produzidas pela natureza e a força de trabalho da classe trabalhadora.

\section{OFICINA N ${ }^{\circ} 1$}

Todo sujeito acontece na linguagem e com a linguagem. Acontecer na linguagem, como sujeito, é se dar conta de que consumimos signos quando comemos, ouvimos, olhamos, cheiramos e tocamos as coisas. Assim, respectivamente, produtos da culinária afrodescendente, a exemplo da série acarajé, abará, pimenta, poderiam dialética e virtualmente se opor à série McDonald's numa escala e multiplicidade planetária; a música tonal para contemplar as alturas não é a mesma coisa da atonal para tocar a terra e sentir seu próprio peso; o fetichismo burguês formata 
a realidade de um jeito, a possibilidade libertária, fundada no valor de uso e na socialização da riqueza, implica objetividades novas e outros mundos inaugurais; em vez de crack e cocaína, o cheiro de frutas maduras entre ramagens ou nas lembranças luminosas; e sempre tocar a pele enrugada como festa da existência. Os signos que consumimos podem nos consumir ou serem reelaborados e constituírem a performance de cada um como criadores ou reprodutores de realidades.

A palavra não nasce agarrada à coisa que representa; uma coisa representada pode, além da palavra, ser recoberta de outros signos, embora haja sempre uma comunidade semântica que encene um imperativo da fala e imponha uma transcendência do significado; uma multiplicidade de agências (a escola, a Igreja, o Estado, o partido, o dicionário) que eleja e dissemine sujeitos de enunciação (pastores, políticos, professores, dicionaristas) e uma lógica que imponha um modo de pensar e que pode cercear os sujeitos consumidores de signos, além de bloquear sua potência de pensar e de perguntar.

Perguntar sobre quem é que é isso ou aquilo, sob que condições históricas e políticas recebeu tal e qual significado, sob que artimanhas circula numa dada comunidade linguística, qual o ponto de sua implosão ${ }^{4}$ aberto a sujeitos criadores de realidades é garantir e sustentar um consumo ativo dos signos e/ou representações que não paramos de consumir. 
Uma multiplicidade de comunas socialistas e libertárias, do ponto de vista do materialismo cultural, pressupõe a existência de uma inteligência estético-política entre associações de homens, mulheres e crianças livres, capazes ao mesmo tempo de esvaziar o sentido do poder político absoluto e o sentido absoluto de qualquer signo.

\section{OFICINA N ${ }^{\circ} 2$}

Tomemos a Parada Disney como uma feira de signos em movimento e imaginemos, além das crianças enfeitiçadas pelo espetáculo, uma invasão de outras crianças que implodissem simbolicamente seus carros alegóricos. Mamulengos e bonecos de pano ridicularizando o sorriso do capital embaixo das perninhas levantadas da pequena princesa ou a serialização de pequenos monstrengos diante do espelho da Branca de Neve. Ou, ainda, o derramamento de baldes de tinta vermelha ou sacos de "Q-Suco" de groselha simulando as ondas do mar sobre o qual trafegaria o barco do Peter Pan e suas aventuras capitalistas pelo mundo.

Já que uma metaparada Disney (crianças produzindo oficinas desconstrutivas durante o cortejo) ou uma metanovela das oito, na Globo (cenas desmontando truques melodramáticos), não costuma fazer parte dos livros didáticos que são impostos às escolas de formação básica brasileiras, por que não inventarmos outra pedagogia do 
lúdico (nós, críticos culturais, artistas, professores, produtores, agitadores e consumidores de cultura massiva e hegemônica), começando por uma arqueologia dos videogames? Imaginem uma festa na escola em que estudantes, em oficinas preparatórias, construíssem a indumentária de seus personagens prediletos e os encenassem numa guerra de símbolos.

OFICINA N ${ }^{\circ} 3$

A constituição de um coletivo não pode prescindir de um devir coletivo de cada indivíduo nem de um devir indivíduo desse mesmo coletivo. O devir coletivo de cada indivíduo significa deixar-se marcar, consumir representações como formas de valor e de perspectivas inaugurais e práticas continuadas. O devir indivíduo do coletivo significa a constituição de um corpo, uma corporação, com vontades alinhadas por princípios e traduzidas por uma sintaxe. O problemático na constituição desses devires é: destruir o indivíduo em nome do coletivo e destruir o coletivo como imposição de um indivíduo.

Há duas noções de coletivo e de indivíduo que precisam aqui ser esconjuradas para que a ciência como ação direta, e disponível a qualquer grupelho, possa ser de novo reencenada e praticada. A primeira noção de indivíduo destruída pelo coletivo deriva da prática nazifascista na política e disseminada por segmentos artísticos e culturais 
(a Parada Disney, por exemplo). Sua lógica de destruição implica agir em nome de Deus, da família, da pátria e da propriedade, ou ainda em nome da raça pura, para, em primeiro lugar, impedir o indivíduo do acesso a uma tecnologia do signo (quem inventou Deus?, como sobreviver sem o gregarismo da família, como fazer da língua uma pátria dos desterritorializados?, quem estabeleceu o cercado, criou as leis que o legitimaram e o projetaram para além dos tempos, constituindo assim uma metafísica da propriedade privada?) e, em segundo, impedi-lo do acesso à mobilização de um coletivo que multiplique as formas de Deus, da família como princípio de uma estética da existência. Mátrias no lugar de pátrias. O sentido sem $a$ priori e como acontecimento em movimento.

A segunda noção de indivíduo destruída pelo coletivo deriva da prática stalinista na política e disseminada por segmentos artísticos culturais. Sua lógica de destruição implica agir em nome do partido, comunista, evocando seus fundadores, mas traindo e falsificando seus princípios. Um exemplo histórico: a destruição física de dezenas de milhares de bolcheviques revolucionários ou, de forma mais branda, a imposição de uma autocrítica como forma de humilhação pública e de destruição de suas forças de subjetivação. Condição na qual qualquer revolucionário, destituído de sua potência de devir coletivo, se suicidaria ou se tornaria um farrapo humano ante o grande czar.

A prática stalinista disseminada por segmentos artísticos culturais já não se configura mais em impor o chamado 
realismo socialista aos artistas ${ }^{5}$ e suas obras, proibindo-lhes a experimentação e impondo-lhes a propaganda partidária como valor estético e universal da classe trabalhadora (artistas e suas obras tiveram energia semiótica suficiente para não sucumbirem a tal barbárie), mas em separar a cultura da política como se formas de fazer e praticar política (mesmo no Estado e entre partidos e sindicatos) não fossem cultura, não dependessem de homens, mulheres, que nomeiam situações, produzem representações, fundam lógicas de governar e controlar, e estão, por sua condição histórica, completamente vulneráveis aos que detêm a tecnologia dos signos.

OFICINA N ${ }^{\circ} 4$

Em Metodologia da Pesquisa em Crítica Cultural e no Curso de Formação de Gestores, Produtores, Artistas e Agitadores Culturais, ambos desenvolvidos no Mestrado em Crítica Cultural do Departamento de Educação do Campus II, Alagoinhas (DEDC II/UNEB), ensaia-se, permanentemente, uma arte de pesquisar como técnica de arrombamento e ocupação de espaços epistemológicos - eis algumas cenas e princípios:

\section{CENA $N^{\circ} 1$}

Se a riqueza material existente na face da Terra deriva da natureza (água, ar, minérios, luz) e da força de trabalho 
vendida pelos trabalhadores, então é preciso anular e reverter a lógica capitalista que: a) valoriza apenas o produto do trabalho e coloca toda a riqueza na mão de poucos rentistas e parasitas; b) faz do fetiche e do simulacro a realidade nossa de cada dia, impedindo abstrações e objetivações de outras formas de realidade fundadas na "est-ética" do trabalho e da vida socialista; c) coloca no poder representantes da classe média para destruírem as formas de organização dos trabalhadores e/ou encenarem uma organização mecanicista e burocrática do socialismo condenada ao idealismo e à pura abstração.

CENA $N^{\circ} 2$

A crítica cultural só faz sentido se se investe contra essa lógica capitalista, se se implode permanentemente essa noção de cultura que se quer hegemônica, e emerge em cada trabalhador, em cada sujeito anônimo, em cada tribo, em cada coletivo, em cada comunidade, em cada nação, como caixa de ferramentas que permita a cada um, ou em coletividade, a redefinição de uma cultura alternativa e como máquina de guerra.

CENA $N^{\circ} 3$

Cultura como máquina de guerra implica uma experiência estética e vitalista: se forças da barbárie tentam separar a vida daquilo que a vida pode, as forças plásticas e afirmativas, por outro lado, permitem à vida resistir, criar 
no limite do que pode, inclusive para transformar essas forças da barbárie em forças afirmativas.

\section{CENA $N^{\circ} 4$}

Toda crítica cultural deve também partir de uma cultura da linguagem: quem nomeou isso e/ou aquilo e sob que condições? Como esvaziar os significados transcendentais e conferir sentido ao mundo de acordo com a nossa potência de renomeá-lo, poetizá-lo? O peso do mundo não deve ficar nem com os camelos, pois esse peso é só uma palavra e seus fantasmas.

CENA $N^{\circ} 5$

Se o ato de conhecer envolve obstáculos que dizem da predisposição do espírito de quem quer conhecer algo e, ao mesmo tempo, das conquistas técnicas, terminológicas, metodológicas, teóricas de um dado campo do conhecimento, então a crítica cultural deve, antes de tudo, estimular seus pesquisadores a reverem suas memórias como um arquivo público, a lerem um arquivo público como uma série de poemas, a produzirem conhecimento sempre experimentalmente e na fronteira de todas as disciplinas.

\section{CENA $N^{\circ} 6$}

Se nas frestas e tocas de todos os simulacros e falsificações sobre quem de fato e de direito pode usufruir de toda a riqueza material existente, há um mercado cultural 
anônimo, uma ética e uma estética socialista surda, uma multiplicidade de sintaxes entre os excluídos, formas indiciárias de intercâmbio e coexistência de todas as temporalidades e, acontecendo em todos os lugares, formas de guerrilhas como em jogos de videogames, então está na hora de começarmos a socializar essas técnicas de arrombamento da lógica cultural do capitalismo tardio, como afirmação de uma política pública cultural heterotópica.

A exemplo da Comuna de Paris, deve-se desarmar os soldados do prefeito, do governador e do presidente e armar o povo com muitos livros, bibliotecas comunitárias, cinemas digitais, ilhas de produção caseiras e/ou de fundo de quintal, e garantir a eleição, através de amplo debate público, de outros representantes, bem como destituí-los do poder, tão logo traiam o seu mandato. Os salários, remunerações, dos novos agentes culturais devem tomar como parâmetro a cultura do dinheiro em movimento na economia solidária e nas cooperativas de consumo e de produção, e termos como único parâmetro de justiça a apropriação da matéria-prima, das máquinas e das fábricas, e distribuí-las a quem de fato produz a riqueza material existente.

\section{ANARTIVISMO INDÍGENA NO BRASIL E O CREPÚSCULO DO ESTADO}

Embora não mobilizemos uma teoria do Estado descrevendo sua natureza e função como pessoa jurídica de 
direito público, ${ }^{6}$ e daí fazer derivar uma imagem de seu crepúsculo, acreditamos que o conjunto de informações e argumentos aqui arrolados e sob o crivo da crítica cultural poderá indicar uma série de roteiros relevantes para o anartivismo indígena, considerado como uma atividade da memória sobre uma sociedade contra o Estado, que não existe mais ou não existe ainda.

Comecemos, então, com o artigo sexto da Constituição brasileira, de 1988: "São direitos sociais a educação, a saúde, a alimentação, o trabalho, a moradia, o lazer, a segurança, a previdência social, a proteção à maternidade e à infância, a assistência aos desamparados, na forma desta Constituição.” A ele pode ser confrontado o artigo quinto: “Todos são iguais perante a lei, sem distinção de qualquer natureza, garantindo-se aos brasileiros e aos estrangeiros residentes no País a inviolabilidade do direito à vida, à liberdade, à igualdade, à segurança e à propriedade", e alguns de seus incisos: o "XXII - é garantido o direito de propriedade", o "XXIII - a propriedade atenderá a sua função social” e o "XXX - é garantido o direito de herança”.

Considerando que a atual Constituição brasileira foi discutida e promulgada quase 500 anos depois das ordens de despejo das nações indígenas, 100 anos depois de mais de 300 anos de escravidão do povo negro - para ficarmos em dois exemplos -, qual seria, então, o sentido de "direito à propriedade", de "direito de herança", 
enquanto "iguais perante a lei" e como condições aos direitos sociais, como educação, saúde, trabalho, lazer, e segurança, entre outros?

Se compusermos o arquivo contendo documentos e testemunhos relativos a essas ordens de despejo dos povos indígenas, bem como os relativos aos 300 anos de escravidão do povo negro, nossa Constituição cidadã não deveria tratar apenas de direitos - o que, a rigor, se torna uma retórica vazia -, mas de reparação, isto é, reconhecimento do genocídio, devolução das terras aos índios que restaram, política cultural específica, além do pagamento em espécie aos remanescentes de índios e de escravos.

Se o Estado assim procedesse - e qualquer senso comum identifica, aqui, um especial sentido de justiça -, teríamos uma primeira imagem do Estado funcionando como um instrumento de mediação entre o capital e o trabalho. E mais que isso: mediaria o empoderamento, legítimo, daqueles que foram excluídos, para, então, fazerem sentido as noções de propriedade e de herança.

Senão, qual seria a propriedade desses despejados? Qual seria, ainda, a herança a seus filhos e descendentes? Eis aqui, de forma surpreendente, a primeira imagem crepuscular do Estado.

O Estado, depois de séculos ou mesmo milênios sendo combatido por parte das sociedades contra o Estado entre as nações indígenas pré-cabralinas, ${ }^{7}$ não teria emergido, com a modernidade histórica e filosófica, como uma instituição forte, emancipadora, a favor e sob o controle da 
sociedade civil organizada? Isso porque toda a teoria do Estado moderno, mesmo as mais conservadoras, indica que, com seu advento, com a constituição de seus poderes (Executivo, Legislativo, Judiciário), institui-se uma forma de racionalidade jurídico-política em que o povo, mesmo sob toda a forma de controle interno a cada país e em suas colônias, além de personagem principal do discurso acerca da democracia, é um elemento estruturante, sem o qual o Estado não faria sentido. Assim, o paradoxo constitutivo do Estado parece ser, desde o seu nascimento, o seguinte: foi instituído em nome do empoderamento do povo, mas para controlá-lo e destituí-lo de toda e qualquer forma de poder, em nome do povo.

Com a emergência da Comuna de Paris, em 1871, e os escritos teóricos de Marx e Engels, compreende-se por que o poder deve ser um espaço vazio e sob controle de communards que, ao mesmo tempo, legislam e executam, transformam o exército de guardiões do poder para lutar ao lado do povo, em armas, destituem dos altos salários todo o servidor público, socializam riquezas e serviços públicos, ${ }^{8}$ ou, mais que isto, conforme Marx: se o Estado é sempre controlado pela classe que está no poder (no caso, a burguesia), então seria necessário colocá-lo na mão dos trabalhadores que, abolindo a propriedade privada, transformando os burgueses em trabalhadores e distribuindo, equitativamente, as riquezas, não só a luta 
de classes seria abolida, mas a vida humana tornar-se-ia, enfim, uma obra de arte. ${ }^{9}$

A Comuna de Paris, sob liderança anarquista, atingiu, ao longo de 72 dias, essa obra de arte, não pela dizimação de artistas e trabalhadores, por parte da contrarrevolução burguesa, mas pela forma de luta e conquistas libertárias para a humanidade; já os Estados socialistas, liderados pelo stalinismo, entre 1924 e 1954, além de acabar com o espaço público do debate, dizimar os dissidentes, controlar e submeter a obra de arte como propaganda de regimes burocráticos e autoritários, acabou com o sonho e a utopia socialista. Eis aqui uma segunda imagem do crepúsculo do Estado.

A terceira imagem crepuscular do Estado reúne os elementos que destruíram tanto a Comuna de Paris, como ascensão da classe trabalhadora ao poder e como sujeito político, quanto a rebelião de Canudos, como expressão política de pobres e subalternos na periferia do mundo capitalista, ambas as destruições em nome da República. O mesmo gesto de destruição, e em nome da República, vai se repetir no nazifascismo clássico e contemporâneo. $\mathrm{Ou}$ seja, o crepúsculo do Estado se dá a ver não pelo enfraquecimento da lei, como um imperativo e execução despótica, mas pela inviabilidade ou esvaziamento do direito.

Se o Estado é uma invenção cultural, que sob o comando da sociedade civil, dos trabalhadores, teria a função de 
abolir a luta de classes e, inclusive, de destruir a si mesmo, como prova de sua potência, o que estamos vivendo, nas chamadas democracias contemporâneas, é o seu estertor.

O que aconteceria ao "Estado democrático contemporâneo" se os índios, os negros, as mulheres, os homossexuais, as crianças, os professores, os trabalhadores subalternos, a exemplo dos communards, utilizassem o seu direito constitucional de se reunir, de divulgar suas deliberações, de se colocarem em movimento, onde quer houvesse uma prescrição e imposição de uma lei?

A escola suportaria o estudo, a crítica e a prática política referentes aos seus regimentos e estatutos por parte dos estudantes, professores e técnico-administrativos? A desordem escolar, ou a desordem pública, não seria uma forma de expressão de resistência dos subcidadãos à violência do Estado quanto à inviabilização de seus direitos previstos constitucionalmente? E se, além de cumprir o seu dever como instituição de direito público e a favor do direito dos cidadãos, o Estado ainda investisse na politização do povo, haveria desordem pública?

Ao considerar a malha jurisdicional, em todos os setores da vida social, a imagem de um Estado forte seria aquela em que déspotas, com máscaras de soberanos, seriam indiferentes às pessoas no espaço público e imporiam e executariam a lei ou, radicalmente ao contrário, aquela em que representantes da multiplicidade de grupos submetessem a lei à apreciação pública como um conjunto de signos vazios e esvaziáveis, cujos representantes comunitários, em 
assembleias, tivessem o direito inalienável, e sem burocracia, de suprimir essa mesma lei?

Diante dessa imagem do Estado, o que seria, então, a noção de minorias a(nar)tivistas? Minorias ativistas, sem engajarem sua subjetividade como cultura política que desloquem o Estado, não há dúvida, contentam-se com migalhas e doações, como sinônimo de bondade pública, e sem colocarem em questão nem a lei nem a instituição, com seus doadores, pois, provavelmente, seus corpos, sua língua, tenham sido esvaziados de sua força ou simplesmente agem sem refletir. Famintos que estão, apenas adoram e deliram, além de serem indiferentes e confundirem política com religião, e vice-versa.

Minorias a(nar)tivistas são de outra natureza. Mobilizando os restos de uma sociedade contra o Estado e apostando numa teoria do fim do Estado como transição para uma sociedade em que figure uma multiplicidade de associações de homens, mulheres e crianças livres, as minorias "anartistas" ou "anartivistas" esvaziam o texto da lei pelo fulgor da vida como estética da existência ou obra de arte. Daí o sentido de as diferentes etnias indígenas no Brasil, além da demarcação de suas terras e do livre direito de preservação de sua cultura, ainda quererem aprender a se expressar em língua indígena, como arqueologia de sua vida plástica e artística, em harmonia com a natureza.

Se tomarmos, dos arquivos coloniais, também acessados pelos índios atuais, estes versos do Auto representado na Festa de São Lourenço, do padre José de Anchieta, ${ }^{10}$ em que 
o índio pintado de diabo diz "Que bom costume é bailar! / Adornar-se, andar pintado, / tingir pernas, empenado / fumar e curandeirar, / andar de negro pintado", vemos que o sentido de se aprender a língua tupi, atualmente, não só seria um modo de avaliar a gramática da língua construída pelo colonizador e difundida entre colonizadores, mas de rever a relação entre os nomes e as coisas (repetições em tupi dos valores religiosos e cosmológicos medievais), reposicionar as manifestações e vontades do tradutor, além de devassar a lógica subjacente de suas proposições ou discurso.

O que aconteceria se estudantes e professores indígenas compusessem outro material, também bilíngue, a partir desses documentos e, além de questionarem e esvaziarem as prescrições para a língua portuguesa contidas nos Parâmetros Curriculares Nacionais, criassem, conforme direito previsto na Constituição brasileira, em seu capítulo I (artigo quinto, inciso XVIII), associações e cooperativas com a função de institucionalizar, gerir, produzir material que fizesse circular outras formas de reinvenção de si e de suas comunidades? Eis o texto do inciso: "a criação de associações e, na forma da lei, a de cooperativas independem de autorização, sendo vedada a interferência estatal em seu funcionamento". Não haveria aqui uma dobra para encenação de uma sociedade sem Estado?

A experiência de ocupação de espaços institucionais, através de secretarias de governo, combinada com a de 
produção de material artístico e cultural com caráter de reversão do discurso colonial, por meio de associações e cooperativas, não só seria um dispositivo para se ativarem as sociedades contra o Estado, mas um laboratório para a emergência de sociedades sem Estado.

A atividade a(nar)tivista, por parte de minorias indígenas seria, ao mesmo tempo, uma forma de visibilizar a potência do Estado, em processo de perecimento e por isso a favor de uma poética da existência, bem como, ao contrário, visibilizar o seu completo crepúsculo e decadência, arrastando consigo o homem ocidental e sua noção de humanidade.

O poema a seguir, intitulado "potyra kwarasy suí osem agwã” - escrito em língua tupi, acompanhado de tradução para o português de minha autoria -, e como um dos resultados da oficina de língua tupi, ministrada pela professora Consuelo de Paiva Godinho Costa da Universidade do Sudoeste da Bahia (UESB), em maio de 2014, tanto é a abertura de uma série de atividades de um projeto de extensão filiado ao Programa de Pós-Graduação em Crítica Cultural, focando o estudo permanente e regular de língua, literatura e cultura indígena como um projeto piloto de implantação de língua tupi na educação fundamental e média, quanto uma dobra teórica para se pensar o sentido de autobiografia como prática micropolítica e de resistência ${ }^{11}$ aos aparelhos de Estado. 
potyra kwarasy suí osem agwã

uma flor sairá do sol

gwapenum

ondas do mar

gwapenum

ondas do mar

gwapenum

ondas do mar

nde îasy i

xe îasy asepiak

eu vejo a lua

mas não há lua

nde xe îasytata'y i

xe îasytata'y i omãê pe eu olho para as estrelas

mas não há estrelas

xe mamoã asepiak

eu vejo apenas vagalumes

nde mamoã resepiak

você vê apenas vagalumes

a'e mamoã osepiak

ele, ela vê apenas vagalumes

îandé mamoã îasepiak

nós vemos apenas vagalumes

oré mamoã rosepiak

nós (exceto os não índios)

[vemos apenas vagalumes

peê mamoã pesepiak

vocês veem apenas vagalumes

a'e mamoã osepiak

eles, elas veem

[apenas vagalumes

potyra îandé ma'enduar kwarasy

uma flor sairá do sol

osem agwã

de nossas lembranças

gwapenum

ondas do mar

gwapenum

ondas do mar

gwapenum

ondas do mar 
Nessa perspectiva, podemos visibilizar no poema um mapa ${ }^{12}$ para o trabalho autobiográfico anartista ou anartivista indígena, a saber: a evocação das ondas do mar, em seu movimento de irem e virem, e com o sentido de colocarem em cena os restos e os rastros da civilização indígena, tanto retoma a forma teatral indígena de opor a natureza à civilização, quanto mostra o corpo do índio sem imunização ocidental. É através do mar e suas ondas que os índios celebram seu encontro com a natureza, principalmente porque todos os sentidos do seu corpo são ativados: do barulho das ondas à música atonal, do brilho do sol sobre as águas à potência de ver e de rememorar, do gosto do sal como antídoto às doenças de branco ao cheiro da vida marinha para se tocar a existência em todo seu esplendor.

No segundo ponto do mapa, o sujeito poético que vê a lua onde ela não existe ou não está, que olha para as estrelas para que se esquivem do seu olhar, esses gestos apontam para a existência de uma liderança indígena, um cacique, um pajé, um curumim, uma matriarca, ou simplesmente a liderança de um artista da existência, um índio, que dá forma a sua existência, a seus modos de vida, a sua prática política a partir, também, dos signos da natureza e não apenas através de suas línguas.

A passagem do sujeito da primeira pessoa, o "eu" poético, para o "tu" ou o "você", o "ele" e "ela", o "nós", como expressão do coletivo indígena, bem com a passagem dessa singularidade para as demais pessoas do plural, em que todos aparecem mergulhados na escuridão iluminada 
apenas por vagalumes, além de indicar um canto coletivo de uma comunidade que vê na natureza a arqueologia de sua existência e do primado de sua civilização, aponta, ao mesmo tempo, e quando define um "nós" referente aos não índios, o contraste da luz dos vagalumes ao excesso de luz própria da civilização ocidental e sua barbárie. Eis aqui imbricados o terceiro e quarto pontos do mapa.

As lembranças, iluminadas de sol, das quais brotará a flor da vida comunal, implicam um agenciamento saudável e sem ressentimento dos signos da barbárie ocidental que fez adoecer o corpo indígena ao ser submetido a todos os tipos de doenças e dispositivos de caça, fome, tortura, escravidão, aprisionamento mental e dizimação em massa, bem como, além desse agenciamento, uma ativação dos signos da civilização indígena que lutou com todas as suas forças contra o advento do Estado.

O eterno retorno e vaivém das ondas do mar indicam uma seleção em espiral em que, além de novos encontros entre índios e não índios, num trabalho coletivo e comunal de ativação da memória de uma civilização forte, estabelece o crivo de uma sociedade sem Estado: sem rei, sem despotismo, sem capital para a domesticação dos corpos, sem imperialismo do significante, sem vida nua ${ }^{13}$ e sem o peso da lei inviabilizando os direitos. ${ }^{14}$

Autobiografias sem essa potência política são apenas outros modos de enredar-se, cada vez mais, na malha do fetichismo etnocêntrico, com seus simulacros e processos de subjetivação. 


\section{CONCLUSÃO}

“A história não se muda com lágrimas." Essa frase, do filme Terra em transe (1967), de Glauber Rocha, dá o tom da experiência trágica que vivíamos no final dos anos de 1960, auge da Guerra Fria entre a União Soviética e os Estados Unidos, e que se arrasta até a Queda do Muro de Berlim (1989) e a Derrocada do Bloco Soviético (1991). Para além dos milhões de mortos, em consequência dos conflitos de guerras, mundiais e regionais, e de pós-guerra, pairava a ameaça sobre a vida humana na terra, caso os arsenais nucleares, das potências em questão, fossem detonados.

Uma das relações de força que subjaz a esses conflitos ou a essa experiência trágica pode ser definida ou caracterizada pela noção de "luta de classes". Se Marx não tivesse descoberto que, ao longo da história da humanidade, há classes que vão se formando por seu poderio econômico, militar, científico e religioso e, por conta desse poderio, vão dominando outras classes menos poderosas, e que essas classes menos poderosas poderiam ter seu ponto de partida revolucionário com a união de todos os trabalhadores 
explorados, não fosse essa descoberta, ou seja, essa relação de força dialética e contraditória de uma classe (detentora dos modos de produção), que procura escravizar, alienar e separar a outra daquilo que ela pode (apropriar-se da matéria-prima, das máquinas e das fábricas, bem como da racionalidade política do Estado), não teria emergido uma epistemologia articulada a uma multiplicidade de programas e organizações políticas revolucionárias voltadas à demolição do capital e suas instituições, ao longo de mais um século.

O sentido de luta desarmada dos subalternos, aqui, evoca, necessária e simbolicamente, três grandes períodos, a saber: 1848-1989/1991, mais ou menos 150 anos da primeira publicação do Manifesto do Partido Comunista, por Marx e Engels; 1871-1989/1991, mais ou menos 120 anos da eclosão da Comuna de Paris, liderada e pensada pelos anarquistas; 1500-1991, faltando mais ou menos 10 anos para a celebração dos 500 anos de Brasil. O primeiro período supõe a existência de partidos comunistas ao redor do mundo, bem como a existência de sindicatos onde quer que haja uma fábrica, uma empresa, uma rede de comércio ou um parlamento pelo qual se possa disputar o poder em sua forma legislativa, executiva e judiciária. O segundo período supõe a existência de organizações contra a burguesia e suas instituições, bem como uma crítica radical das formas de organização marxistas, por entender que estas, por princípio, sucumbem à forma do Estado e sua racionalidade "transbordante de cérebros". 
O terceiro período supõe uma ausência - a sociedade contra o Estado - que tomou forma na interpretação do Brasil, mas que constitui uma virtualidade capaz de reunir o marxismo e o anarquismo como uma expressão política do povo pobre e subalterno.

Dito isso, e de um ponto de vista da civilização brasileira, marxismo não se opõe ao anarquismo, e vice-versa; nem as sociedades contra o Estado, que estão na base do pensamento e prática política dos povos indígenas, devem ser consideradas como atrasadas, conforme as prescrições do etapismo stalinista. Sendo assim, um roteiro para se pensar e praticar um anartivismo estético-político envolveria uma equação com os seguintes termos: onde há uma dobra ou um tentáculo do capital e seu pacote fetichista (o Estado, a religião, o simulacro), há também, e numa relação de força, uma pergunta do marxismo (quem produz a riqueza material existente, além da natureza e da classe trabalhadora, e a quem essa riqueza deve retornar, na forma de justiça simbólica e social), um desordenamento anarquista para melhor se vislumbrarem e esvaziarem as formas de poder reativas e, como contribuição radicalmente brasileira, uma comunidade de homens, mulheres e crianças livres pactuada com a natureza e senhora de um tempo "cairológico", entre o presentismo do mundo globalizado e o etapismo stalinista e seus similares.

Com a Queda do Muro de Berlim e a Derrocada do Bloco Soviético, os Estados Unidos, na liderança da chamada Nova Ordem Mundial, reinam quase absolutos, mas tendo 
como consequência disso o conformismo avassalador e reativo e o terrorismo, com seus homens-bomba, agindo em diferentes lugares e situações, como se fossem novos sindicalistas. Assim a construção de uma epistemologia dedicada à luta desarmada, e envolvendo essa multidão sem nome, nem rosto, pode, outra vez, abrir condições para um devir político e poiético da humanidade.

A luta desarmada dos subalternos pode ser lido a partir de qualquer um de seus tópicos, e sob as mais diferentes combinações, visando não apenas a uma reflexão sobre a possibilidade de uma política de desarmamento das grandes potências, mas, principalmente, a um empoderamento do leitor como um anartivista capaz tanto de dar forma às situações de perigo por que passa sua vida cotidiana quanto de imprimir seu estilo como se vivesse numa sociedade contra o Estado, mas com uma caixa de ferramentas anarcomarxistas. 
NOTAS

\section{INTRODUÇÃO}

1 Raymond Williams, A política e as letras, trad. André Glaser, São Paulo, Editora Unesp, 2013, p. 62.

2 Silviano Santiago, Outubro retalhado (entre Estocolmo e Frankfurt), em O cosmopolitismo do pobre, Belo Horizonte, Editora UFMG, 2004, p. $74-90$.

3 Ibidem, p. 78.

4 Gilles Deleuze e Félix Guatarri, Introdução: rizoma, em Mil platôs: capitalismo e esquizofrenia, trad. Aurélio Guerra Neto e Celia Pinto Costa, Rio de Janeiro, Editora 34, 1995, v. 1.

5 Ibidem.

6 Gilles Deleuze, O que é pensar?, Foucault, 2. ed., São Paulo, Brasiliense, 1991, p. 124-130.

\section{CAPÍTULO 1}

1 Bertold Brecht, Los días de La Comuna. Turandot: o El congreso de los blanqueadores, trad. Miguel Sáenz, Madrid, Alianza Editorial S.A., 2001. 
2 Roberto Schwarz (org.), Os pobres na literatura brasileira, São Paulo, Brasiliense, 1983.

3 Silviano Santiago, O cosmopolitismo do pobre: crítica literária e crítica cultural, Belo Horizonte, Editora UFMG, 2004.

4 Horácio González, A Comuna de Paris: os assaltantes do céu, São Paulo, Brasiliense, 1989.

5 Karl Marx, A guerra civil na França, trad. Rubens Enderle, São Paulo, Boitempo, 2011.

6 Vladimir Ilitch Lenin, O Estado e a revolução. A revolução proletária e o renegado Kautsky, trad. Henrique Canary, São Paulo, Editora Instituto José Luis e Rosa Sundermann, 2005.

7 Michel Foucault, Metodologia para o conhecimento do mundo: como se desembaraçar do marxismo, em Ditos e escritos: repensar a política, trad. Ana Lúcia Paranhos Pessoas, Rio de Janeiro, Forense Universitária, 2010, v. VI.

8 Brecht, Los días de La Comuna.

9 Gilles Deleuze, Nietzsche e a filosofia, trad. Ruth Joffily Dias e Edmundo Fernandes Dias, Rio de Janeiro, Editora Rio, 1976.

${ }^{10}$ Elisa Cevasco, Dez lições sobre estudos culturais, São Paulo, Boitempo, 2003.

11 Silviano Santiago, Atração do mundo: políticas de globalização e de identidade na moderna cultura brasileira, em O cosmopolitismo do pobre, p. 11-44.

12 Santiago, O cosmopolitismo do pobre.

${ }^{13}$ Gilles Deleuze, Bartleby, ou a fórmula, em Crítica e clínica, trad. Peter Pál Pelbart, São Paulo, Editora 34, 1997.

${ }^{14}$ Laura de Mello e Souza, Notas sobre os vadios na literatura colonial do século XVII: Antonil e Teixeira Coelho, em Schwarz (org.), Os pobres na literatura brasileira, p. 9-12.

15 Antonio Dimas, Gregório de Matos Guerra ao português, em Schwarz (org.), Os pobres na literatura brasileira, p. 13-20.

16 Alexandre Eulálio, O pobre, porque é pobre, pague tudo: Gonzaga, em Schwarz (org.), Os pobres na literatura brasileira, p. 21-25. 
17 Vilma Arêas, No espelho do palco: Martins Pena, em Schwarz (org.), Os pobres na literatura brasileira, p. 26-30.

18 Silviano Santiago, Imagens do remediado: M. A. de Almeida, em Schwarz (org.), Os pobres na literatura brasileira, p. 31-34.

19 Alcides Villaça, O nosso poeta dos escravos: Castro Alves, em Schwarz (org.), Os pobres na literatura brasileira, p. 40-45.

${ }^{20}$ Roberto Schwarz, A velha pobre e o retratista: Machado de Assis, em Schwarz (org.), Os pobres na literatura brasileira, p. 46-50.

${ }^{21}$ Walnice Nogueira Galvão, Uma ausência: Euclides da Cunha, em Schwarz (org.), Os pobres na literatura brasileira, p. 51-53.

${ }^{22}$ Zulmira Ribeiro Tavares, Rembrants e papangus: Domingos Olímpio, em Schwarz (org.), Os pobres na literatura brasileira, p. 54-62.

${ }^{23}$ Giorgio Agamben, Estado de exceção, trad. Iraci D. Poleti, São Paulo, Boitempo, 2004.

24 Antonio Arnoni Prado, Mutilados da belle-époque: João do Rio, em Schwarz (org.), Os pobres na literatura brasileira, p. 63-72.

25 Beatriz Resende, Lima Barreto: a opção pela marginália, em Schwarz (org.), Os pobres na literatura brasileira, p. 73-78.

${ }^{26}$ Francisco Foot Hardman, Palavra de olho, cidade de palha, em Schwarz (org.), Os pobres na literatura brasileira, p. 79-87.

27 Lígia Chiappini, João Simeão Lopes Blau ou a arte de ser Zaoris, em Schwarz (org.), Os pobres na literatura brasileira, p. 88-100.

${ }^{28}$ Marisa Lajolo, Jeca Tatu em três tempos: Monteiro Lobato, em Schwarz (org.), Os pobres na literatura brasileira, p. 101-105.

${ }^{29}$ Davi Arrigucci Jr., O humilde cotidiano de Manuel Bandeira, em Schwarz (org.), Os pobres na literatura brasileira, p. 106-122.

30 Telê Porto Ancona Lopez, Riqueza de pobre: Mário de Andrade, em Schwarz (org.), Os pobres na literatura brasileira, p. 123-128.

31 Maria Eugênia Boaventura, Oswald de Andrade, a luta da posse contra a propriedade, em Schwarz (org.), Os pobres na literatura brasileira, p. 129-135.

32 Maria Simon, Na praça de convites: C. Drummond de Andrade, em Schwarz (org.), Os pobres na literatura brasileira, p. 140-148. 
33 Suzi Frankl Sperber, Jovem com ferrugem: C. Lispector, em Schwarz (org.), Os pobres na literatura brasileira, p. 154-164.

${ }^{34}$ Modesto Carone, Severinos e comendadores: J. Cabral de Mello Neto, em Schwarz (org.), Os pobres na literatura brasileira, p. 165-169.

35 Clara de Andrade Alvim, Representações da pobreza e da riqueza em Guimarães Rosa, em Schwarz (org.), Os pobres na literatura brasileira, p. 170-174.

${ }^{36}$ José Paulo Paes, Samba, estereótipos, desforra: Adoniran Barbosa, em Schwarz (org.), Os pobres na literatura brasileira, p. 175-181.

37 Haroldo de Campos, Arte pobre, tempo de pobreza, poesia menos: Machado, Oswald, Graciliano, Cabral, Augusto de Campos, em Schwarz (org.), Os pobres na literatura brasileira, p. 181-189.

38 João Luiz Machado Lafetá, Dois pobres, duas medidas: Ferreira Gullar, em Schwarz (org.), Os pobres na literatura brasileira, p. 190-200.

39 Berta Waldman, A medida do cafajeste: Dalton Trevisan, em Schwarz (org.), Os pobres na literatura brasileira, p. 201-203.

${ }^{40}$ Carlos Vogt, Trabalho, pobreza e trabalho intelectual: Carolina de Jesus, em Schwarz (org.), Os pobres na literatura brasileira, p. 204-213.

${ }^{41}$ Maria José Londres, O sertanejo valente na literatura de cordel, em Schwarz (org.), Os pobres na literatura brasileira, p. 238-243.

${ }^{42}$ Giorgio Agamben, O que resta de Auschwitz, trad. Selvino J. Assmann, São Paulo, Boitempo, 2008.

${ }^{43}$ Santiago, $O$ cosmopolitismo do pobre.

44 Idem, Democratização do Brasil (1979-1981): cultura versus arte, em O cosmopolitismo do pobre, p. 134-155.

45 Idem, Atração do mundo, p. 11-44.

${ }^{46}$ Idem, A aula inaugural de Clarice Lispector: cotidiano, labor e esperança, em O cosmopolitismo do pobre, p. 231-240.

${ }^{47}$ Idem, Outubro retalhado (entre Estocolmo e Frankfurt), em O cosmopolitismo do pobre, p. 74-90.

${ }^{48}$ Idem, Intensidades discursivas, em $O$ cosmopolitismo do pobre, p. 125-133.

49 Leon Trotski, Literatura e revolução, trad. Luiz Alberto Moniz Bandeira, Rio de Janeiro, Jorge Zahar Editor, 2007. 
${ }^{50}$ Giorgio Agamben, O homem sem conteúdo, trad. Cláudio Oliveira, Belo Horizonte, Autêntica, 2012.

51 Robert Service, Lenin: a biografia definitiva, trad. Eduardo Francisco Alves, Rio de Janeiro, DIFEL, 2006, p. 29.

52 Ibidem, p. 40.

53 Eric Hobsbawn, Era dos extremos: o breve século xx: 1914-1991, trad. Marcos Santarrita, revisão técnica Maria Célia Paoli, São Paulo, Companhia das Letras, 1995, p. 367.

54 Trotski, Literatura e revolução.

55 Gilles Deleuze, Lógica do sentido, trad. Luiz Roberto Salinas Fortes, São Paulo, Perspectiva, 1988, p. 308.

\section{CAPÍTULO 2}

1 Jacques Derrida, Essa estranha instituição chamada literatura: uma entrevista com Jacques Derrida, Belo Horizonte, Editora UFMG, 2014.

2 Gayatri Spivak, Pode o subalterno falar?, trad. Sandra Regina Goulart Almeida, Marcos Pereira Feitosa e André Pereira Feitosa, Belo Horizonte, Editora UFMG, 2010.

3 Michel Foucault, Os intelectuais e o poder, em Microfísica do poder, 4. ed., trad. Roberto Machado, Rio de Janeiro, Graal, 1984, p. 69-78.

4 A história de Qiu Ju, direção de Zhang Yimou, Hong Kong, [s.n.], 1992, 110 min., son., color., legendado, tradução de Qiu Ju da guan si.

5 Michael Hardt e Antonio Negri, Multidão: guerra e democracia na era do império, trad. Clóvis Marques, Rio de Janeiro, Record, 2005.

6 Giorgio Agamben, Altíssima pobreza, trad. Selvino J. Assmann, São Paulo, Boitempo, 2014.

7 Ibidem, p. 20.

8 Ibidem, p. 50.

9 Giorgio Agamben, O homem sem conteúdo, trad. Cláudio Oliveira, Belo Horizonte, Autêntica, 2012. 
10 Gilles Deleuze, Conversações, trad. Peter Pál Pelbart, Rio de Janeiro, Editora 34, 1992.

11 Gilles Deleuze, O ato de criação, trad. José Marcos Macedo, Folha de S.Paulo, 27 jun. 1999. Caderno Mais!, p. 6.

12 J. M. Coetzee, The Master of Petersburg, London, Vintage Books, 1999.

13 Vladímir Sorókin, Dostoiévski-Trip, trad. Arlete Cavaliére, São Paulo, Editora 34, 2014.

14 "El revolucionario es un hombre que ha sacrificado su vida. No tiene negocios ni asuntos personales ni sentimientos ni ataduras; ni propiedades, ni siquiera un nombre... Un solo pensamiento, una única pasión: La Revolución” (Juan J. Alcalde (org.), Bakunin - Netchaiev: El catecismo revolucionario, p. 3, disponível em <http://www. christiebooks.com/PDFs/Bakunin-Netchaiev.El\%20Catecismo\%20 Revolucionario.pdf>, acesso em 21 abr. 2015.

15 "I write perversions of the truth. I choose the crooked road and take children into dark places. I follow the dance of the pen" (Coetzee, The Master of Petersburg, p. 236, tradução minha).

16 Arlete Cavaliére, Pósfácio, em Vladímir Sorókin, Dostoiévski-Trip, trad. Arlete Cavaliére, São Paulo, Editora 34, 2014, p. 75-99.

17 Gao Wenqian, Zhou Enlai: o revolucionário perfeito, trad. Flávio Souto Maior, Rio de Janeiro, Record, 2012.

18 Mo Yan, Mudança, trad. Amilton Reis, São Paulo, Cosac Naify, 2013.

19 Gao Xingjian, Le témoignage de la littérature, trad. Liliane Dutrait e Noël Dutrait, Paris, Seuil, 2004.

20 René Dumont, Les communes populares rurales chinoises, Persée: Revues Scientifiques, v. 29, n. 4, 1964, p. 380-397, disponível em <http://www.persee.fr/web/revues/home/prescript/article/polit_0032-342x_1964_num_29_4_2269>, acesso em 5 abr. 2015.

${ }^{21}$ István Mészáros, Poder político e dissidência nas sociedades pós-revolucionárias, em Para além do capital: rumo a uma teoria da transição, trad. Paulo Cezar Castanheira e Sérgio Lessa, São Paulo, Boitempo, 2002, p. 1012-1031. 
“Cela ne consiste qu'à parler sans point de départ ni point d'arrivée, à parler sans aboutir à aucune conclusion" (Gao Xingjian, Témoignage de la littérature, Paris, Seuil, 2004).

23 Émile Benveniste, Problemas de linguística geral, trad. Maria da Glória Novak e Maria Luisa Neri, São Paulo, Editora Pontes, 2005, p. $48-49$.

\section{CAPÍTULO 3}

1 Étienne Balibar, A filosofia de Marx, trad. Lucy Magalhães, Rio de Janeiro, Jorge Zahar Editor, 1995.

2 Silviano Santiago, A democratização no Brasil (1979-1981): cultura versus arte, em O cosmopolitismo do pobre: crítica literária e crítica cultural, Belo Horizonte, Editora UFMG, 2004, p. 134-155.

3 Idem, $\mathrm{O}$ assassinato de Mallarmé, em Uma literatura nos trópicos: ensaios sobre dependência cultural, São Paulo, Perspectiva, 1978, p. 188-199.

4 Luiz Costa Lima, A praga do beletrismo, Eutomia, ano 2, v. 2, 30 dez. 2009, disponível em <http://www.revistaeutomia.com.br/volumes/ ano2-volume2/artigo-extra/a-praga-do-beletrismo.pdf $>$, acesso em 27 nov. 2013.

5 Gustave Courbet, Carta aos artistas de Paris, Verve, n. 15, p. $123-$ 125, 2009, disponível em: <https://we.riseup.net/assets/190146/ Gustave\%20Coubert\%20Carta\%20aos\%20artistas\%20de\%20paris. pdf>, acesso em 15 out. 2014.

6 Euclides da Cunha, Os sertões: campanha de Canudos, 36. ed., Rio de Janeiro, Francisco Alves, 1995.

7 Charles Baudelaire, As flores do mal, tradução, introdução e notas de Ivan Junqueira, ed. bilíngue, Rio de Janeiro, Nova Editora, 1985.

8 Ferdinand de Saussure, Mémoire sur le système primitif des voyelles dans les langues indo-européennes, Leipsick, B. G. Teubner, 1879.

9 Idem, Curso de linguística geral, org. Charles Bally e Albert Sechehaye, colab. Albert Riedlinger, pref. à edição brasileira Isaac Nicolau Salum, 
trad. Antonio Chelini, José Paulo Paes e Izidoro Blikstein, 28. ed., São Paulo, Cultrix, 2012.

10 Leon Trotski, Literatura e revolução, trad. Luiz Alberto Moniz Bandeira, Rio de Janeiro, Jorge Zahar Editor, 2007.

${ }^{11}$ Idem, A cultura e a arte proletárias, em Literatura e revolução, p. 155.

12 Vladimir Ilitch Lenin, A organização do partido e a literatura do partido, em Obras completas, São Paulo, Alfa Ômega, 1980, v. 12, p. 101.

13 Giorgio Agamben, O que resta de Auschwitz: o arquivo e a testemunha - Homo Sacer III, trad. Selvino J. Assmann, São Paulo, Boitempo, 2008.

${ }^{14}$ Wilton Oliveira, Artistas, anarquistas e trotskistas em Amado stalinista, Dissertação (Mestrado) - Programa Crítica Cultural, Universidade do Estado da Bahia, Alagoinhas, 2012.

15 Giorgio Agamben, Infancia e historia: destrucción de la experiencia y origen de la historia, trad. Silvio Mattoni, Cordoba, Argentina, Adriana Hidalgo Editora, 2011, p. 211, tradução minha.

${ }^{16}$ István Mészáros, O século XXI: socialismo ou barbárie?, trad. Paulo Cesar Castanheira, São Paulo, Boitempo, 2003.

17 Ibidem.

18 Georg Lukács, O que é marxismo ortodoxo?, em História e consciência de classe: estudos sobre dialética marxista, trad. Rodnei Nascimento, São Paulo, Martins Fontes, 2003, p. 63-104.

19 Carregadoras de sonho, direção de Deivison Fiuza, Aracaju, Sindicato dos Professores de Sergipe (SINTESE), WG Produções, 2010, 65 min., son., color.

${ }^{20}$ Fredric Jameson, $O$ inconsciente político: a narrativa como ato socialmente simbólico, trad. Valter Lellis Siqueira, São Paulo, Ática, 1992.

${ }^{21}$ Roland Barthes, Aula, trad. Leyla Perrone-Moisés, São Paulo, Cultrix, 1980.

22 Gilles Deleuze, Terceira série: da proposição, em Lógica do sentido, trad. Luiz Roberto Salinas Fortes, São Paulo, Perspectiva, 1974. 
Silviano Santiago, O cosmopolitismo do pobre: crítica literária e crítica cultural, Belo Horizonte, Editora UFMG, 2004.

${ }^{24}$ Neide Luzia de Rezende, A “formação do leitor" na escola pública brasileira: um jargão ou um ideal?, em Congresso da ABRALIC: Internacionalização do Regional, 13., Anais... Campina Grande-PB, UECG, 8-12 jul. 2013, Mesa-redonda: Ensino de Literatura em Perspectiva Comparada.

${ }^{25}$ Dermeval da Hora, A área de letras e linguística: novos desafios (conferência de abertura), em Encontro Nacional da ANPOLL, 28., Anais... Florianópolis-SC, UFSC, 1-3 jul. 2013.

26 Thaïs Cristófaro Silva, Formação em letras e linguística hoje: desafios e conquistas (palestra), em Encontro Nacional da ANPOLL, 28., Florianópolis-SC, UFSC, 1-3 jul. 2013, Mesa-redonda: Ensino de Literatura em Perspectiva Comparada.

27 Sérgio Vaz, Literatura periférica, Caros Amigos, ano XIX, n. 221, p. 6, 2015.

${ }^{28}$ Norberto Bobbio, Estado, governo, sociedade: por uma teoria geral da política, 11. ed., trad. Marco Aurélio Nogueira, São Paulo, Paz e Terra, 2004.

\section{CAPÍTULO 4}

1 Giorgio Agamben, Infancia e historia: destrucción de la experiência $y$ origen de la historia, trad. Silvio Mattoni, Córdoba, Argentina, Adriana Hidalgo Editora, 2011.

2 Confrontar os livros Posições, de Jacques Derrida (trad. Tomaz Tadeu da Silva, Belo Horizonte, Autêntica, 2001), e Curso de linguística geral, de Ferdinand de Saussure (org. Charles Bally e Albert Sechehaye, colab. Albert Riedlinger, pref. à edição brasileira Isaac Nicolau Salum, trad. Antonio Chelini, José Paulo Paes e Izidoro Blikstein, 28. ed., São Paulo, Cultrix, 2012).

3 Para uma introdução ao materialismo cultural, ver Maria Elisa Cevasco, Para ler Raymond Williams, São Paulo, Paz e Terra, 2001. 
4 Ver Gilles Deleuze, Lógica do sentido, trad. Luiz Roberto Salinas Fortes, São Paulo, Perspectiva, 1988.

5 Para uma reversão dessa noção de realismo socialista, ver Fredric Jameson, $O$ inconsciente político: a narrativa como ato socialmente simbólico, São Paulo, Ática, 1992; e Leon Trotski, Literatura e revolução, trad. Luiz Alberto Moniz Bandeira, Rio de Janeiro, Jorge Zahar Editor, 2007.

6 Norberto Bobbio, Estado, governo, sociedade: por uma teoria geral da política, trad. Marco Aurélio Nogueira, 11. ed., São Paulo, Paz e Terra, 2004.

7 Pierre Clastres, A sociedade contra o Estado, 4. ed., trad. Theo Santiago, Rio de Janeiro, Francisco Alves, 1988.

8 Vladimir Ilitch Lenin, $O$ Estado e a revolução. A revolução proletária e o renegado Kautsky, trad. Henrique Canary, São Paulo, Editora Instituto José Luis e Rosa Sundermann, 2005.

9 Trotski, Literatura e revolução.

${ }^{10}$ José de Anchieta, Auto representado na Festa de São Lourenço, Rio de Janeiro: Serviço Nacional de Teatro - Ministério da Educação e Cultura, 1973, p. 12.

11 Jacques Derrida, Essa estranha instituição chamada literatura: uma entrevista com Jacques Derrida, trad. Marileide Dias Esqueda, Belo Horizonte, Editora UFMG, 2014.

12 Gilles Deleuze e Félix Guattari. Introdução: Rizoma, em Mil platôs: capitalismo e esquizofrenia, trad. Aurélio Guerra e Célia Pinto Costa, Rio de Janeiro, Editora 34, 1995, v. 1.

${ }^{13}$ Giorgio Agamben, Homo sacer: o poder soberano e a vida nua I, trad. Henrique Burigo, Belo Horizonte, Editora UFMG, 2010.

${ }^{14}$ Giorgio Agamben, Estado de exceção, trad. Iraci D. Poleti, São Paulo, Boitempo, 2004. 


\section{SOBRE O AUTOR}

Osmar Moreira dos Santos - Professor titular de Literatura da Universidade do Estado da Bahia (UNEB). Líder do grupo de pesquisa Lingua(gem) e Crítica Cultural, criado por meio do Diretório 5.0 do CNPq, e membro do corpo permanente do Programa de Pós-Graduação em Crítica Cultural vinculado à UNEB. Publicou Um Oswald de bolso: crítica cultural ao alcance de todos (2010), o artigo "Viva o povo brasileiro: escrita e fabulação antropofágica” (2013), pela Revista Ipotesi, além de capítulos de livros e artigos em periódicos de circulação nacional e internacional. 
A presente edição foi composta pela Editora UFMG e impressa pela Imprensa Universitária UFMG, em sistema offset, com papel pólen soft $80 \mathrm{~g}$ (miolo) e cartão supremo 300g (capa), em julho de 2016. 